\title{
Taxonomic assessment of Leptodoras (Siluriformes: Doradidae) with descriptions of three new species
}

\author{
Mark Henry Sabaj
}

The genus Leptodoras Boulenger is a monophyletic assemblage of at least ten species distributed in large, predominantly lowland rivers throughout the northern half of cis-Andean South America. Leptodoras is diagnosed in Doradidae (thorny catfishes) by unique morphologies of the oral hood (upper labial extensions distinct with comparatively smooth ventral surface, lateral margins of extensions entire, weakly scalloped or fimbriate and without marginal papillae, and interlabial membranes of narrow or moderate width), first gill arch (enlarged accessory lamellae extend well onto medial face of gill filaments), and gas bladder (reduced size and modified cordiform shape, two distinct horn-like diverticula project from posterior walls of posterior chambers, and a pair of bulbous diverticula project from lateral walls of anterior chamber). Examination of specimens of Leptodoras from throughout its range verified the distinctiveness of the seven nominal species (L. acipenserinus, L. copei, L. hasemani, L. juruensis, L. linnelli, L. myersi and L. praelongus) and revealed three new species described herein (Leptodoras nelsoni, L. rogersae, and L. cataniai). A lectotype for L. hasemani is designated.

O gênero Leptodoras Boulenger é um agrupamento monofilético com pelo menos dez espécies, distribuídas em rios grandes e predominantemente de terras baixas na metade norte da região cis-Andina da América do Sul. Leptodoras é diagnosticado em Doradidae pelas morfologias únicas da região bucal (extensões labiais superiores distintas com superfície ventral comparativamente lisa, margens laterais destas extensões inteiras, fracamente franjadas ou fimbriadas e sem papilas marginais, e membranas interlabiais estreitas a moderadamente largas), do primeiro arco branquial (lamellas acessórias aumentadas, extendendo-se pela face medial dos filamentos branquiais), e da bexiga natatória (tamanho reduzido e formato cordiforme modificado, dois divertículos em forma de guampas projetando-se das paredes posteriores das câmaras posteriores, e um par de divertículos bulbosos projetando-se das paredes laterais da câmara anterior). O exame de exeplares de Leptodoras em sua área de distribuição permitiu a distinção de sete espécies nominais (L. acipenserinus, L. copei, L. hasemani, L. juruensis, $L$. linnelli, L. myersi e L. praelongus) e revelou três espécies novas, descritas aqui (Leptodoras nelsoni, L. rogersae, e $L$. cataniai). É designado um lectótipo para L. hasemani.

Key words: Barbel morphology, Longlip thornycat, Taxonomic key, Thorny catfishes.

\section{Introduction}

Leptodoras Boulenger (longlip thornycats) is a monophyletic genus of the Doradidae (Order Siluriformes) comprised of seven previously described and three new species distributed in large, predominantly lowland rivers throughout the northern half of cis-Andean South America. Leptodoras is easily recognized by its long conical snout and well-developed oral hood formed by the membranous union of maxillary barbels, paired jaw barbels and labial structures. The oral hood presumably facilitates the detection and suction-feeding of shallowly buried invertebrates. Stomach contents typically include chironomid larvae, sand and detritus (pers. obs.).
Most species of Leptodoras are truly benthic and typically inhabit the deep swift-flowing waters of large rivers. Like most fimbriate-barbel doradids many species of Leptodoras migrate at dusk into shallow waters near shore to forage over beaches and shoals of sand or silt. Other species of Leptodoras (e.g., L. juruensis, L. myersi) appear more restricted to deep channel habitats and are best captured via bottom trawls at depths of up to $50 \mathrm{~m}$ (J.G. Lundberg, unpubl. data). Leptodoras is not known from elevations exceeding $500 \mathrm{~m}$ above sea level and most records are from below $200 \mathrm{~m}$. Species are distributed throughout lowlands in the Orinoco, Amazon and Tocantins basins and several coastal river systems (e.g., Essequibo) that enter the Atlantic between the

Department of Ichthyology, The Academy of Natural Sciences, 1900 Benjamin Franklin Parkway, Philadelphia, Pennsylvania, USA 19103. e-mail:sabaj@acnatsci.org 
mouths of the Orinoco and Amazon. Leptodoras is not known from trans-Andean drainages (e.g., Maracaibo and Magdalena) or Atlantic-slope drainages south of the rio Tocantins (e.g., rios São Francisco and Paraná-Paraguay).

The taxonomic history of Leptodoras dates back to Günther's (1868a) description of Oxydoras acipenserinus from the Peruvian Amazon. Boulenger (1898) subsequently proposed the genus Leptodoras, designated L. acipenserinus the type, and described a second species, L. juruensis, from the rio Jurua, Brazil. Boulenger (1898) distinguished Leptodoras as having a longer body and longer anal fin (15 to 17 rays) than Oxydoras Kner. Eigenmann (1912) doubted the diagnosability of Leptodoras based on anal-fin ray counts, but retained Leptodoras as distinct because of its lack of teeth. Eigenmann (1912) introduced a third species, L. linnelli, described from the Essequibo river basin, Guyana. Steindachner (1915) described Hemidoras hasemani based on 18 syntypes from the rio Branco and one specimen, reidentified here as Hemidoras stenopeltis (Kner), from the mouth of the rio Negro, Brazil. Eigenmann (1925) transferred hasemani to Leptodoras and provided the first detailed de-

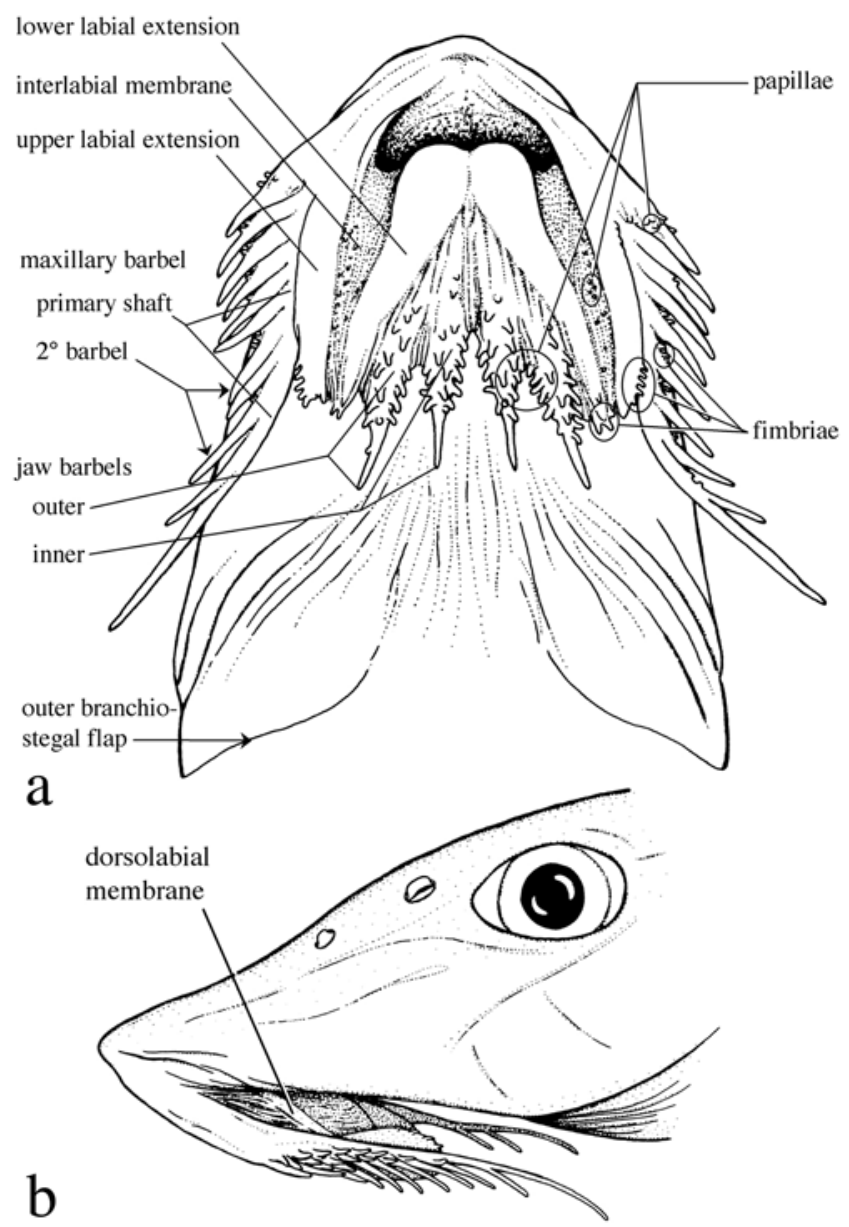

Fig. 1. Standard terminology for features of barbels and labial structures in Leptodoras. a. Ventral view of head in L. linnelli, ANSP 175883 (SL $94 \mathrm{~mm}$ ). b. Lateral view of head in L. nelsoni, MCNG 13167 (SL $93 \mathrm{~mm}$ ). scription of the genus. Myers \& Weitzman (1956) described Hassar praelongus from the rio Negro, Brazil, and FernándezYépez (1968) described Anduzedoras copei from the Orinoco Basin, Venezuela. Most recently, L. myersi was described by Böhlke (1970) from specimens collected in a deep-water trawl of the río Amazonas near Iquitos, Peru.

Although all seven nominal Leptodoras are valid species, their identification in the literature (L. juruensis excepted) is often inconsistent. Taxonomic confusion has been the product of several factors: 1) several species (L. praelongus, $L$. copei, L. hasemani) closely resemble one another or species in other genera (e.g., Hassar), 2) the distributions and identities of two species (acipenserinus and linnelli) have been misunderstood, 3) all seven species were described from small geographic areas (usually a single locality) with no information on their potential distributions, and 4) specimens (especially adults) have been rare in museums until very recently.

Increased sampling efforts over the past decade, particularly those utilizing bottom trawls (e.g., the Calhamazon Project led by J.G. Lundberg), have yielded large numbers of Leptodoras specimens. These recent collections and a survey of the primary types (all extant) made this study possible. Perhaps the most surprising discovery resulted from the examination of specimens routinely identified as $L$. acipenserinus or L. linnelli. This revealed three undescribed species distributed in the main channel of the río Orinoco, the Colombian and Venezuelan llanos (Orinoco drainage) and Amazon basin, respectively.

The objectives of this paper are to diagnose the genus Leptodoras and its nominal species and to describe three new species.

\section{Material and Methods}

Institutional abbreviations follow Leviton et al. (1985) with the addition of UNT for Universidade do Tocantins, Porto Nacional, Brazil. Standard terminology for features of barbels and labial structures was developed to facilitate their description (Fig. 1). Measurements were made to the nearest $0.1 \mathrm{~mm}$ using digital calipers ( $<150 \mathrm{~mm}$ ), dial calipers ( 150 to $180 \mathrm{~mm}$ ) or a beam compass ( $>180 \mathrm{~mm})$. Measurements and corresponding landmarks (Fig. 2) coincided in part with those of Böhlke (1970) and Higuchi et al. (1990). Some measurements were changed to improve repeatability (via better landmarks) or to synchronize the terminus of one with that of another. Poorly defined landmarks (e.g., those requiring physical manipulation of specimen to visualize) were marked with insect pins.

Point-to-point straight-line measurements (Fig. 2) are defined as follows with the first set reported as percentages of standard length (SL)-snout tip to point on midlateral side of caudal peduncle level with ventroposterior corner of hypural $3+4$ (determined by gently flexing the caudal fin and/or backlighting); head length (HL)-snout tip to posterior-most extremity of fleshy opercular flap; predorsal distance (PdD)snout tip to posterior margin of second nuchal plate coinciding with median sagittal plane; dorsal origin-adipose distance 
(DOAD)-from groove between posterior margin of second nuchal plate (anterior to base of dorsal-locking spine) to posterior-most base of adipose fin; (AdCD)-posterior-most base of adipose fin to point coinciding with posterior terminus of $\mathrm{SL}$; prepectoral distance $(\mathrm{PpD})$-snout tip to point between notch formed by margin of cleithrum and extreme base of pectoral spine (spine positioned at a $30-45^{\circ}$ angle with the long axis of body); pectoral-pelvic distance (PPD)-from base of pectoral spine (terminus of $\mathrm{PpD}$ ) to base of first (anteriormost) pelvic-fin ray (best visualized by abducting pelvic fin); pelvic-anal distance (PAD)-from base of first (anterior-most) pelvic-fin ray to base of first anal-fin ray; anal-caudal distance (AnCD)-from base of posterior-most anal-fin ray to point coinciding with posterior terminus of SL; dorsal spine length (DSL)-from groove between posterior margin of second nuchal plate and base of dorsal locking spine to bony tip of dorsal spine (spine at a $30-45^{\circ}$ angle with the long axis of the body, soft break-away tip excluded if present); pectoral spine length (PSL)-from base of pectoral spine (terminus of PpD) to bony tip (soft break-away tip excluded if present); pelvic fin length (PFL)-from base of first (anterior-most) ray to distal-most tip of anterior fin (not the measurement of an individual ray); anal-fin base (AnFB)-distance between anterior-most and posterior-most bases of anal fin insertion; body depth (BD)greatest distance in median sagittal plane between shallow crest of posterior margin of second nuchal plate (anterior to dorsal-fin origin) and midventral contour of body; caudal peduncle depth (CPD)-least depth of caudal peduncle.

The following set is reported as percentages of predorsal distance (preferred to head length because of ease and accuracy of measurement): horizontal adipose eye diameter (AED)from anterior-most margin (often level with the weakly defined posteroventral corner of the lateral ethmoid forming anterodorsal portion of bony orbit) to posterior-most margin (usually level with bony margin of orbit coinciding specifically with the anteroventral corner of sphenotic) of adipose eyelid; snout length $(\mathrm{SnL})$-snout tip to anterior-most margin of adipose tissue covering eye (adipose eyelid often becomes opaque during preservation and its margin is usually distinguishable from pigmented skin on snout); snout-anterior nares distance (SAND)-snout tip to center of opening of anterior nares (membranous flap ignored); snout-posterior nares distance (SPND)-snout tip to center of opening of posterior nares (flap ignored); snout-posterior orbit distance (SPOD)snout tip to posterior-most bony margin of orbit coinciding specifically with anteroventral corner of sphenotic; anterior

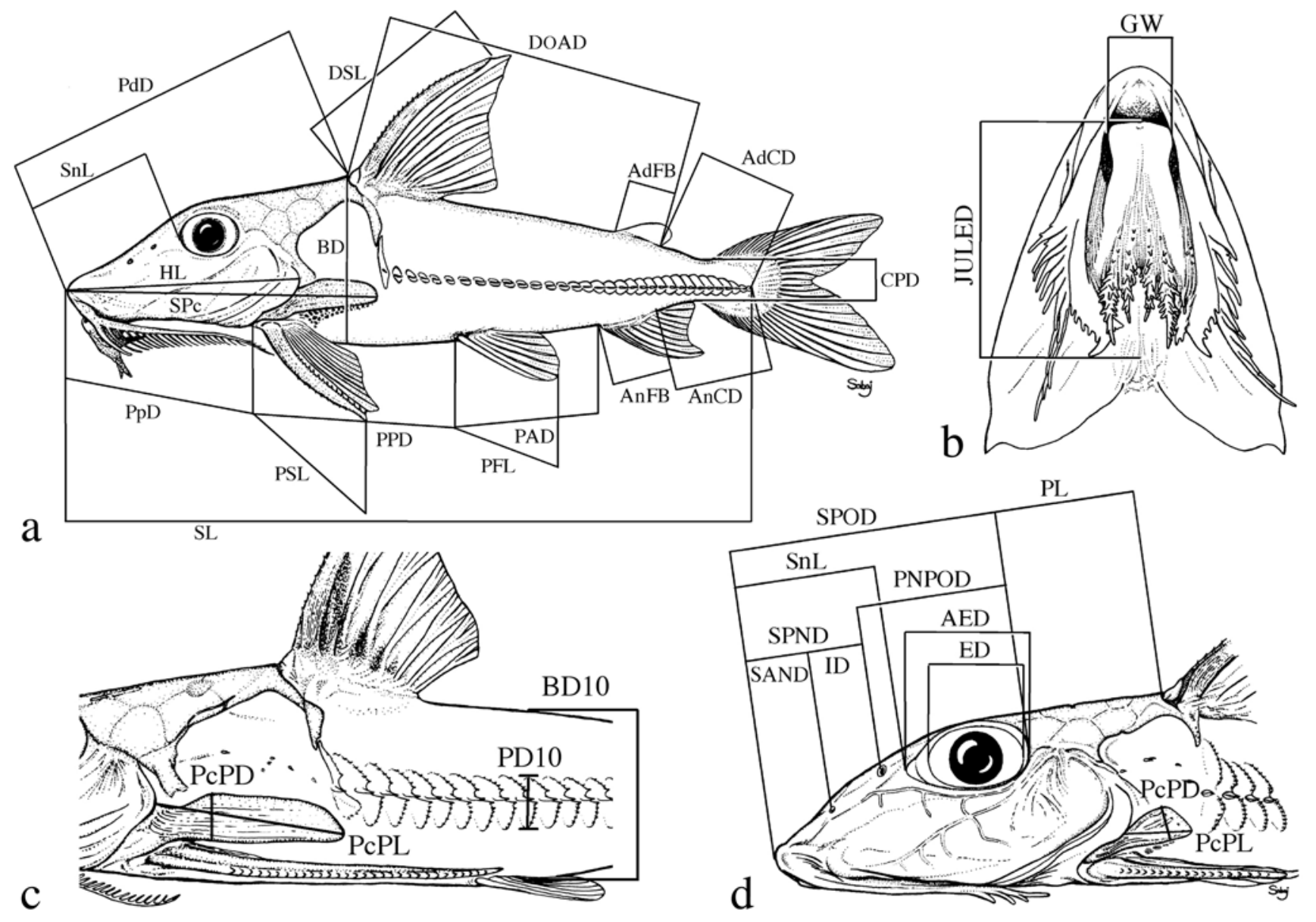

Fig. 2. Landmarks and measurements used for morphometric analysis (shown on generalized doradids). See Material and Methods for explanations of abbreviations. 
nares-posterior orbit distance (ANPOD)-from center of opening of anterior nares to posterior-most bony margin of orbit coinciding specifically with anteroventral corner of sphenotic; posterior nares-posterior orbit distance (PNPOD)-from center of opening of posterior nares to posterior-most bony margin of orbit coinciding specifically with anteroventral corner of sphenotic; internares distance (ID)-between centers of openings of anterior and posterior nares; postorbital length (PL)-from posterior-most bony margin of orbit coinciding specifically with the anteroventral corner of the sphenotic to posterior margin of second nuchal plate coinciding with median sagittal plane; postcleithral (humeral) process length (PcPL)-from posterior-most tip of process to point along anterodorsal margin of exposed process where the cleithral bone is deflected medially (exposed process often appears textured compared to the smooth face of medially deflected portion of the cleithrum and this deflection often coincides with or lies just beneath the posterior-most margin of the fleshy opercular flap); jaw-upper labial extension distance (JULED)-straight-line measurement along median sagittal plane from point level with anterior jaw margin to point level with posterior-most tip of shorter of paired upper labial extensions lying (or pinned) flat against ventral surface of head (performed only on specimens with well preserved labial structures not desiccated or twisted); head width (HW)-greatest transverse distance between lateral contours of head (i.e., opercula compressed to normal position if flared) anterior to cleithra; cleithral width $(\mathrm{CW})$-greatest transverse distance between lateral contours of cleithra; interorbital width (IW)shortest transverse distance between orbital (lateral) margins of bony frontals; gape width (GW)-horizontal measurement between gape corners of closed mouth (in specimens preserved with mouth open, this measurement coincided with the width of the anterior margin of the lower jaw).

One measurement is reported as percentage of body depth taken in the same transverse plane (adapted from Böhlke, 1970): depth of tenth midlateral plate-vertical depth orthogonal to horizontal line formed by medial thorns of plates, from dorsal-most exposed margin of tenth plate to ventral-most margin of corresponding plate.

Counts of fin rays follow Hubbs \& Lagler (1958), Böhlke (1970) and Higuchi et al. (1990). Counts in dorsal, anal, and paired fins are separated into anterior spine (capital roman numeral) or unbranched soft ray (lower-case roman numeral) and posterior branched soft rays (arabic numerals). The small locking bone anterior to dorsal spine is not counted. The last (posterior-most) pectoral-fin ray may appear unbranched (particularly in juveniles). It is counted if clearly segmented with base separate from penultimate ray. In rare instances the last pectoral-fin ray may be followed by a much smaller and rather inconspicuous sliver-like element that is clearly unsegmented. This bony element is not included in the count. The anteriormost anal-fin ray may be extremely small and closely adhered to the second ray. The last anal ray may be simple or composed of two branches with bases joined or in very close proximity (counted as one in either case). Counts of midlateral plates begin with the vertically expanded infranuchal plate that dorsally contacts the posterior nuchal plate and ventrally contacts or approaches the distal tip of the postcleithral process. Though conspicuous and sometimes bearing a medial thorn, the small plate immediately anterior to the
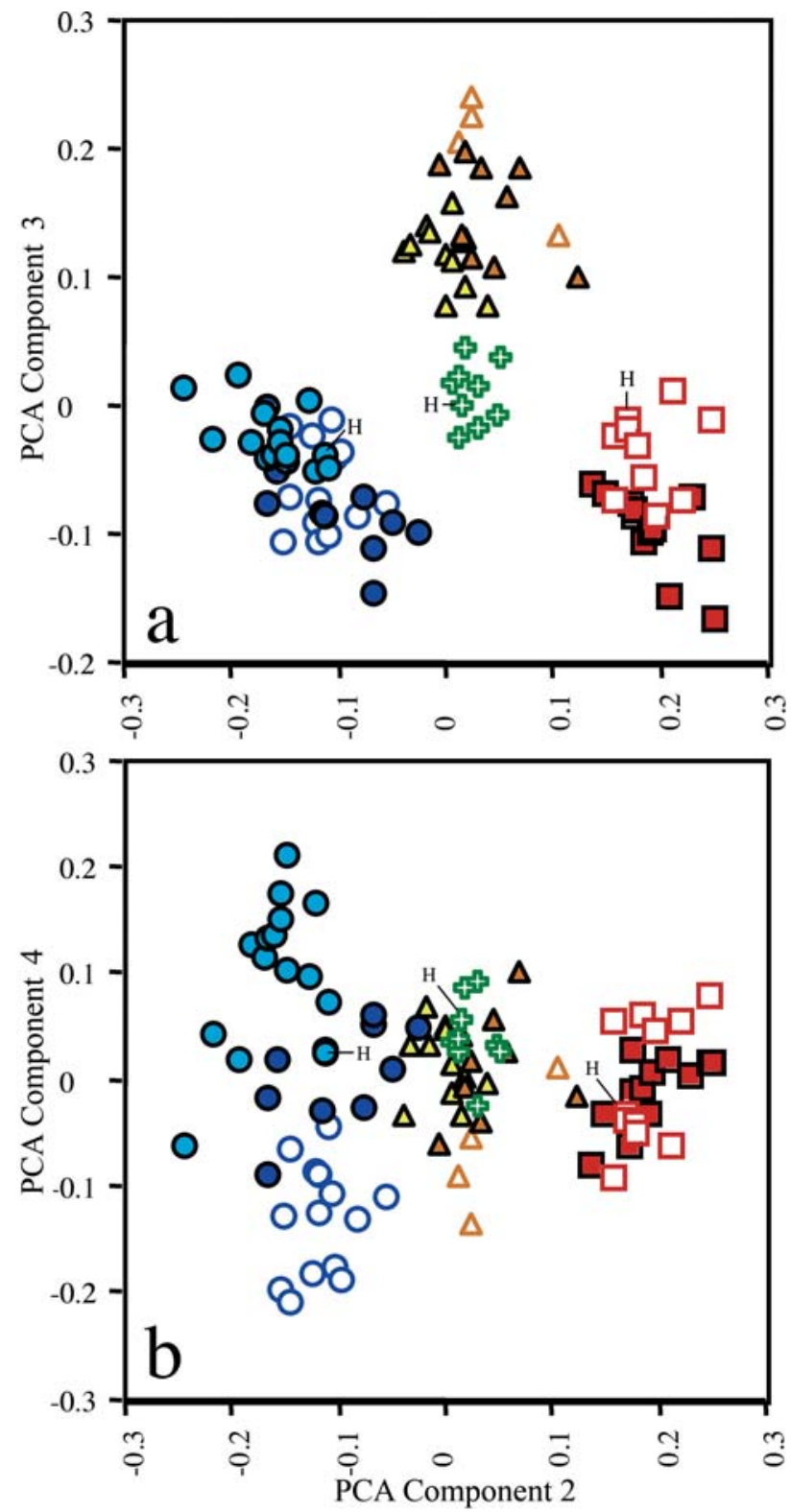

Fig. 3. Scatterplots of scores factored from covariance matrix of 34 log-transformed morphometric variables on principal components axes II vs. III (a) and II vs. IV (b) for 5 species of Leptodoras: L. nelsoni (open squares), L. acipenserinus (shaded squares), L. rogersae (open crosses), L. cataniai (light shaded circles), L. cf. cataniai Amazon form (dark shaded circles), L. cf. cataniai Nanay form (open circles), L. linnelli Essequibo (dark shaded triangles), L. linnelli eastern Guyana Shield (open triangles), L. linnelli Orinoco (light shaded triangles). Holotypes of new species denoted with "H"; measured specimens denoted with asterisk in material examined. 
Table 1. Morphometrics of Leptodoras linnelli, L. acipenserinus, L. nelsoni, and L. rogersae. Measured specimens denoted with asterisk in material examined.

\begin{tabular}{|c|c|c|c|c|c|c|c|c|c|c|c|c|}
\hline & \multicolumn{3}{|c|}{ L. linnelli $(\mathrm{n}=\mathbf{2 5})$} & \multicolumn{3}{|c|}{ L. acipenserinus $(\mathrm{n}=12)$} & \multicolumn{3}{|c|}{ L. nelsoni $(\mathrm{n}=11)$} & \multicolumn{3}{|c|}{ L. rogersae $(\mathrm{n}=10)$} \\
\hline & range & mean & SD & range & mean & SD & range & mean & SD & range & mean & SD \\
\hline 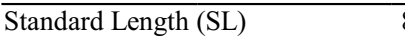 & $84.6-200.6$ & 121.1 & 34.78 & $107.5-196.5$ & 137.4 & 29.68 & $92.3-162$ & 114.7 & 20.49 & $79.9-177.9$ & 108.2 & 28.24 \\
\hline \multicolumn{13}{|c|}{ Percents of Standard length } \\
\hline Head L (HL) & $29.2-33.1$ & 31.2 & 1.09 & $25.6-30$ & 28.1 & 1.26 & $28.1-30.1$ & 29.2 & 0.63 & $28.1-30.5$ & 29.6 & 0.80 \\
\hline Predorsal D (PdD) & $35.5-38.7$ & 37.1 & 0.94 & $31.6-35.6$ & 33.9 & 1.13 & $33-35.2$ & 34.4 & 0.75 & $33.1-36.5$ & 34.8 & 0.96 \\
\hline Dorsal origin-adipose D (DOAD) & $45.7-53.4$ & 48.5 & 1.63 & $48.9-52.4$ & 50.6 & 1.03 & $47.9-51.2$ & 49.8 & 0.86 & $48.7-54.3$ & 50.6 & 1.61 \\
\hline Adipose-caudal D (AdCD) & $16-19.4$ & 18 & 0.87 & $17.4-20$ & 18.6 & 0.88 & $17.4-19.2$ & 18 & 0.54 & $15.7-19.5$ & 17.7 & 1.06 \\
\hline Prepectoral D (PpD) & $24.9-28.6$ & 27.2 & 0.96 & $21.7-25.9$ & 24.4 & 1.29 & $23.7-26.2$ & 25.4 & 0.72 & $23.6-25.9$ & 24.9 & 0.64 \\
\hline Pectoral-pelvic & $15.8-19.8$ & 17.9 & 1.05 & $15.7-18$ & 16.8 & 0.78 & $16.9-18.8$ & 17.7 & 0.68 & $16-17.8$ & 17.2 & 0.59 \\
\hline Pelvic-anal D (PAD) & $25.0-31.4$ & 28 & 1.27 & 27.9-30.8 & 29 & 1.00 & 24.1-29.9 & 27.3 & 1.72 & $27.4-29.8$ & 28.7 & 0.80 \\
\hline Anal-caudal D (AnCD) & $14.2-17.5$ & 15.6 & 0.76 & $15.5-17.6$ & 16.5 & 0.62 & $15.7-17.1$ & 16.4 & 0.50 & 15.4-17.6 & 16.3 & 0.78 \\
\hline Dorsal spine L (DSL) & $20.9-26.3$ & 23.1 & 1.65 & $17.5-23.1$ & 20.7 & 1.70 & $17.9-21.5$ & 20.4 & 1.08 & $15.7-23.4$ & 19.2 & 1.88 \\
\hline $\mathrm{L}(\mathrm{PSL})$ & $19.9-26.2$ & 22.6 & 1.65 & $18.6-21.3$ & 19.8 & 0.88 & $16.7-21$ & 19.1 & 1.37 & $17.6-20.9$ & 18.8 & 0.96 \\
\hline $\mathrm{FL})$ & 13.9-17.4 & 15.6 & 0.88 & $14.2-16.3$ & 15 & 0.64 & $14.9-16.1$ & 15.4 & 0.39 & $15.2-18.6$ & 17.1 & 1.03 \\
\hline ase $(\mathrm{AnFB})$ & $11.5-15.4$ & 13.7 & 1.02 & $14.9-17.3$ & 15.8 & 0.68 & $13.9-18.5$ & 16.1 & 1.40 & 14.1 & 15.1 & 0.64 \\
\hline $\mathrm{Boc}$ & $14.7-17.5$ & 16.1 & 0.81 & 5 & 12 & 0.5 & $13.6-15.6$ & 14.4 & 0.58 & 14.6 & 15.2 & 0.48 \\
\hline Caudal peduncle Depth (CPD) & $4.2-4.8$ & 4.6 & 0.17 & $3.9-4.6$ & 4.2 & 0.23 & $4.2-4.7$ & 4.4 & 0.19 & 4.3 & 4.6 & 0.16 \\
\hline \multicolumn{13}{|c|}{ Percents of Predorsal distance } \\
\hline Head & $81.9-86.3$ & 84.2 & 1.31 & $80.3-84.5$ & 82.8 & 1.30 & $83.7-86.2$ & 85 & 0.97 & $83.6-86.3$ & 85 & 0.89 \\
\hline Adipose eye D ( & $20.3-24.8$ & 22.5 & 0.93 & $15.4-18.1$ & 16.7 & 0.85 & $15.6-19.1$ & 16.8 & 1.09 & $17.6-21.6$ & 19.8 & 1.25 \\
\hline Snout L (SnL) & $39.4-44.4$ & 41.6 & 1.15 & $42.3-46.3$ & 43.8 & 1.39 & $41.6-46.5$ & 43.9 & 1.58 & $37.8-41.8$ & 39.6 & 1.16 \\
\hline Snout-anterior 1 & $22.3-27.4$ & 25.1 & 1.14 & $9-28.7$ & 26.4 & 1.22 & 24.9-28.3 & 26.7 & 1.25 & $6-24.2$ & 22.9 & 0.77 \\
\hline ar porec $\mathrm{D}$ & $34.9-39.2$ & 36.9 & 1.04 & 0.3 & 38.2 & 1.33 & 40 & 38.5 & 0.81 & 33. & 34.9 & 0.69 \\
\hline Snou & $60.1-64.4$ & 62 & 1.02 & .8 & 5 & 1.2 & $57.8-61.6$ & 59.7 & 1.10 & 56.8 & 58 & 0.74 \\
\hline Ant. nares-post. orbit D (ANPOD) & $37.3-41.8$ & 39.3 & 1.00 & $32.6-35.1$ & 34.3 & 0.84 & $33.5-36$ & 34.6 & 0.89 & $34.6-38.5$ & 36.5 & 1.30 \\
\hline Post. nares-post. orbit D (PNPOD) & 26.5-29.7 & 28.5 & 0.97 & 21.4-24.1 & 23.1 & 0.86 & $22.2-23.8$ & 23 & 0.53 & $23.3-26.3$ & 25 & 0.93 \\
\hline Internares D (ID) & $10.5-14$ & 11.9 & 0.85 & $10.7-13.0$ & 11.6 & 0.66 & $10.9-13.8$ & 12 & 0.97 & $11-13.2$ & 12.2 & 0.72 \\
\hline Postorbital L (PL) & $37.6-41.8$ & 39.8 & 1.16 & $40.6-45.5$ & 42.6 & 1.47 & $40.8-43.6$ & 42.2 & 0.84 & $42.9-44.6$ & 43.7 & 0.55 \\
\hline Postcleithral process L (HPL) & $14-18.6$ & 16.1 & 1.15 & $16.2-20.5$ & 18 & 1.22 & $16.4-19.2$ & 17.7 & 0.94 & 14.6-17.8 & 16.3 & 0.97 \\
\hline ext. D (JULED) & $25.5-34.6$ & 29.1 & 2.09 & $20.9-29$ & 25.5 & 2.73 & $19.1-28$ & 24.9 & 2.78 & $29.2-35.5$ & 31.4 & 1.71 \\
\hline Head V & $45.4-54.1$ & 50.6 & 1.97 & $47.1-55$ & 51.1 & 2.22 & $48.6-54.8$ & 52.1 & 1.59 & $48.2-54.2$ & 50.9 & 1.97 \\
\hline Cleithral Wid & $51.3-54.8$ & 52.8 & 0.98 & 54.3-59.9 & 55.9 & 1.91 & $53.8-56.1$ & 54.8 & 0.77 & $53.6-56.1$ & 55.3 & 0.73 \\
\hline ital Width (IW) & $8.3-13$ & 10.3 & 1.36 & $8.7-13.5$ & 11.5 & 1.32 & $9.9-12.1$ & 11.1 & 0.74 & 10.1-11.9 & 10.9 & 0.66 \\
\hline Gape Width (GW) & $8.7-11.9$ & 10.4 & 0.83 & $8.3-10.4$ & 9 & 0.57 & $8.5-12.5$ & 10.2 & 1.23 & $8.6-11.6$ & 10.5 & 0.85 \\
\hline \multicolumn{13}{|c|}{ Percents of Body depth at 10th Scute } \\
\hline Scute D from 10th scute (SD10) & $37.1-54.9$ & 46 & 4.01 & $55.6-73.9$ & 65.1 & 5.99 & 44.3-53.9 & 50.8 & 2.93 & $33.1-44.9$ & 39.8 & 4.16 \\
\hline
\end{tabular}

infranuchal plate (in the tympanal region) is not included in counts of midlateral plates.

Principal Components Analysis (PCA) was used to investigate morphometric variation among Leptodoras acipenserinus, L. linnelli and the three new species. One of the three new species (L. cataniai) was further parsed into three groups: L. cataniai sensu stricto (rio Negro and Casiquiare canal), L. cf. cataniai Amazon form (Amazonas basin excluding Nanay and Negro) and L. cf. cataniai Nanay form (specimens largely from río Nanay, Peru). Leptodoras linnelli also was geographically divided into Essequibo, Orinoco and eastern Guiana Shield (northeastern Brazil) specimens. A total of 34 measurements (Tables $1 \& 2$ ) was taken on 96 juvenile and adult specimens representing a comparable range of sizes: L. acipenserinus ( $\mathrm{n}=12$, SL 107.5-196.5 mm), L. linnelli (25, SL 84.6-200.6 mm), Leptodoras nelsoni (11, SL 92.3-162 mm), Leptodoras rogersae (9, SL 89.2-177.9 mm), L. cataniai sensu stricto (15, SL 97.7-171 mm), L. cf. cataniai Amazon form (10, SL 77.4-194 mm), and L. cf. cataniai Nanay form (14, SL 89.7-181 mm). Specimens used in PCA analyses are denoted by an asterisk in material examined.

Principal components analysis was performed on the covariance matrices of $34 \log$-transformed measurements. The resulting first principal axis (PC I) explained a large proportion of the total variance $(88.6 \%)$ and all variable loadings were positive and varied little in magnitude. PC I was therefore interpreted as a general size factor (Jolicoeur \& Mosimann, 1960; Jolicoeur, 1963; McElroy \& Douglas, 1995). Scores were plotted for PC II, III and IV, interpreted to represent "general-size-allometry-free shape" (Bookstein, 1989).

\section{Results}

Morphometric analysis. Plots of factor scores of principal components II (PCII) vs. III (PCIII) grouped specimens into four non-overlapping clusters corresponding to: Leptodoras linnelli, L. rogersae, L. cataniai + L. cf. cataniai (Nanay and Amazon forms) and L. acipenserinus + L. nelsoni (Fig. 3a). PC II and III accounted for 4.2 and $2.2 \%$ of the total variance, respectively. Measurements loading most heavily on PC II are, in decreasing order: length of upper labial extension (0.086), length of postcleithral process (0.052), adipose-eye diameter (-0.043), interorbital width (0.031), pelvic-fin length $(-0.028)$ and distance from posterior nares to posterior orbit ($0.024)$. Standard length had a loading of 0 on PCII. Measurements loading most heavily on PCIII are, in decreasing order: 
Table 2. Morphometrics of Leptodoras cataniai, L. cf. cataniai (Nanay form) and L. cf. cataniai (Amazon form). Measured specimens denoted with asterisk in material examined.

\begin{tabular}{|c|c|c|c|c|c|c|c|c|c|}
\hline & \multicolumn{3}{|c|}{ L. cataniai $(\mathrm{n}=15)$} & \multicolumn{3}{|c|}{$\begin{array}{c}\text { L. cf. cataniai, } \\
\text { Nanay form }(\mathrm{n}=13)\end{array}$} & \multicolumn{3}{|c|}{$\begin{array}{c}\text { L. cf. cataniai, } \\
\text { Amazon form }(\mathrm{n}=10)\end{array}$} \\
\hline & range & mean & SD & range & mean & SD & range & mean & SD \\
\hline Standard Length (SL) & $97.7-171$ & 138.5 & 21.63 & $89.7-181$ & 122.3 & 28.86 & 77.4-194 & 122.8 & 36.70 \\
\hline \multicolumn{10}{|c|}{ Percents of Standard length } \\
\hline Head L (HL) & 26.9-31.9 & 28.5 & 1.36 & 29.3-32.9 & 30.9 & 1.26 & 27.9-31.4 & 29.2 & 0.99 \\
\hline Predorsal D (PdD) & $31.1-35.5$ & 32.6 & 1.13 & $32.7-37$ & 34.6 & 1.43 & $31.6-35.6$ & 33.1 & 1.23 \\
\hline Dorsal origin-adipose D (DOAD) & $47.7-53.8$ & 51.3 & 1.96 & $45.9-50.8$ & 48.6 & 1.56 & $47.4-51.6$ & 49.7 & 1.63 \\
\hline Adipose-caudal D (AdCD) & $17.2-20.5$ & 18.8 & 1.02 & $16.9-20.2$ & 19.2 & 0.96 & $18.7-20.9$ & 19.6 & 0.58 \\
\hline Prepectoral D (PpD) & $22.6-26.8$ & 24.2 & 1.23 & $24.9-28.5$ & 26.5 & 1.18 & $24.0-26.5$ & 24.9 & 0.66 \\
\hline Pectoral-pelvic D (PPD) & $14.3-17.6$ & 16.2 & 0.97 & $14.1-16.2$ & 15.2 & 0.67 & $15.1-16.9$ & 16 & 0.65 \\
\hline Pelvic-anal D (PAD) & $29.2-31.4$ & 30.1 & 0.60 & $27-29.9$ & 28.6 & 0.99 & 28.4-30.7 & 29.4 & 0.82 \\
\hline Anal-caudal D (AnCD) & $14.7-18.1$ & 16.6 & 1.02 & $14.3-18.5$ & 17.3 & 1.24 & $16.9-18.2$ & 17.5 & 0.47 \\
\hline Dorsal spine L (DSL) & $21.3-27.4$ & 24.2 & 1.82 & $19.7-23.7$ & 21.8 & 1.23 & $18.7-23$ & 20.7 & 1.49 \\
\hline Pectoral spine L (PSL) & $19-21.1$ & 19.9 & 0.64 & $18.3-20.7$ & 19.5 & 0.79 & $17.9-20.8$ & 19.3 & 0.90 \\
\hline Pelvic fin L (PFL) & $15.7-18.5$ & 17.6 & 0.74 & $16.9-19.7$ & 18.3 & 0.73 & $16.9-18.6$ & 17.6 & 0.59 \\
\hline Anal fin Base (AnFB) & $13.7-16.9$ & 14.9 & 0.96 & $13-15.1$ & 14.3 & 0.63 & $12.9-15.3$ & 14.5 & 0.71 \\
\hline Body Depth (BD) & $14.2-15.6$ & 14.7 & 0.52 & $13.7-15$ & 14.2 & 0.44 & $13.5-15.1$ & 14.1 & 0.46 \\
\hline Caudal peduncle Depth (CPD) & $4-4.6$ & 4.3 & 0.16 & $3.4-4.2$ & 3.9 & 0.23 & $3.7-4.4$ & 4 & 0.19 \\
\hline \multicolumn{10}{|c|}{ Percents of Predorsal distance } \\
\hline Head L (HL) & $85-90.6$ & 87.5 & 1.61 & $87.8-91.8$ & 89.5 & 1.05 & $86.1-90.2$ & 88.4 & 1.36 \\
\hline Adipose eye D (AED) & $23.1-27.8$ & 25.5 & 1.49 & $18-21.5$ & 19.7 & 0.99 & $19.8-23.2$ & 21.4 & 1.14 \\
\hline Snout L (SnL) & $35.4-40.2$ & 37.7 & 1.28 & $42.4-46.6$ & 44.1 & 1.26 & $37.6-41.3$ & 39.1 & 1.19 \\
\hline Snout-anterior nares D (SAND) & $19.9-24.6$ & 22.2 & 1.61 & $25.3-28.8$ & 27 & 1.14 & $21.6-25.7$ & 23.3 & 1.25 \\
\hline Snout-posterior nares D (SPND) & $33.6-37.6$ & 35.6 & 0.97 & $36.2-39.4$ & 37.9 & 0.94 & $32-36.7$ & 34.6 & 1.23 \\
\hline Snout-posterior orbit D (SPOD) & $60.2-63.5$ & 61.9 & 0.90 & $60.7-63.9$ & 62.5 & 0.86 & $56.8-61.9$ & 59.3 & 1.52 \\
\hline Ant. nares-post. orbit D (ANPOD) & $39-43.6$ & 41.3 & 1.48 & 34.9-38.9 & 37.3 & 1.24 & $35.7-38$ & 37.1 & 0.75 \\
\hline Post. nares-post. orbit D (PNPOD) & $28.2-30$ & 28.9 & 0.52 & $25.7-28.5$ & 26.8 & 0.74 & $25.1-28.4$ & 26.4 & 1.09 \\
\hline Internares D (ID) & $11.6-16.4$ & 13.5 & 1.38 & $10-13$ & 11 & 0.84 & 9.4-13.6 & 11.7 & 1.06 \\
\hline Postorbital L (PL) & $39.5-41.6$ & 40.7 & 0.76 & $38-40.8$ & 39.6 & 0.74 & $40.8-45.1$ & 42.8 & 1.25 \\
\hline Postcleithral process L (HPL) & $9.9-16.3$ & 13.9 & 1.63 & $11.9-15.3$ & 13.7 & 1.15 & $12.6-17.3$ & 14.2 & 1.24 \\
\hline Jaw-upper labial ext. D (JULED) & $33-44.8$ & 40.8 & 2.84 & $39.3-47.8$ & 44.2 & 2.38 & $36.3-43.8$ & 39.8 & 2.52 \\
\hline Head Width (HW) & $49.6-56.2$ & 52.4 & 1.81 & $47.8-54.2$ & 51.3 & 2.24 & $48.8-54.6$ & 52.2 & 1.67 \\
\hline Cleithral Width (CW) & $52.7-57$ & 55 & 1.25 & $51.2-56.1$ & 54 & 1.18 & $52.5-58.5$ & 56 & 2.09 \\
\hline Interorbital Width (IW) & $7.8-10.6$ & 9.3 & 0.82 & $9.5-11.5$ & 10.5 & 0.67 & $8.8-12.2$ & 10.6 & 1.08 \\
\hline Gape Width (GW) & $9.6-12.8$ & 10.8 & 0.80 & $9.3-12$ & 10.9 & 0.72 & 8.4-11.2 & 9.8 & 1.02 \\
\hline \multicolumn{10}{|c|}{ Percents of Body depth at 10th Scute } \\
\hline Scute D from 10th scute (SD10) & $45.2-60.7$ & 53.1 & 4.88 & $54.2-70.1$ & 61.3 & 4.37 & $40.8-61$ & 53.9 & 5.77 \\
\hline
\end{tabular}

tenth midlateral plate depth (-0.039), adipose eye diameter (0.035), anal-fin base (-0.03), distance from posterior nares to posterior orbit (0.029), and distance from anal fin to terminus of SL (-0.028).

Plots of PCII $v s$. PCIV grouped specimens into three clusters along the $\mathrm{x}$-axis (PCII), one distinct (L. acipenserinus $+L$. nelsoni) and two weakly overlapping corresponding to $L$. cataniai + L. cf. cataniai (Nanay and Amazon forms) and $L$. linnelli + L. rogersae, respectively (Fig. 3b). PCIV contributed very little to the resolution of individual species. However, PCIV (y-axis) did separate L. cataniai and L. cf. cataniai into three weakly overlapping clusters with specimens from the Amazon (L. cf. cataniai Amazon form) intermediate to those from the Negro (L. cataniai sensu stricto) and Nanay (L. cf. cataniai Nanay form). Measurements loading most heavily on PCIV are, in decreasing order: snout-anterior nares distance (-0.039), snout length (-0.029), length of upper labial extension (-0.025), adipose-eye diameter (0.024), internares distance $(0.022)$, and body depth at 10 th plate $(0.021)$.

\section{Leptodoras Boulenger, 1898}

Leptodoras Boulenger 1898:478. Type species: Oxydoras acipenserinus Günther 1868a, by subsequent designation of Eigenmann, 1910:395.

Diagnosis. Leptodoras is diagnosed from other genera of the Doradidae by unique modifications of the oral hood (upper labial extensions distinct, elongate and comparatively smooth with entire, scalloped or fimbriate lateral margins and interlabial membranes narrow or of moderate width), first gill arch (enlarged accessory lamellae on medial face of arch extend well onto medial face of gill filaments), and gas bladder (reduced size, modified cordiform shape, two distinct horn-like diverticula project from posterior walls of posterior chambers and pair of bulbous diverticula project from lateral walls of anterior chamber).

In Leptodoras the labial skin covering the jaws at the corners of the mouth continues posteriorly as a pair of long 

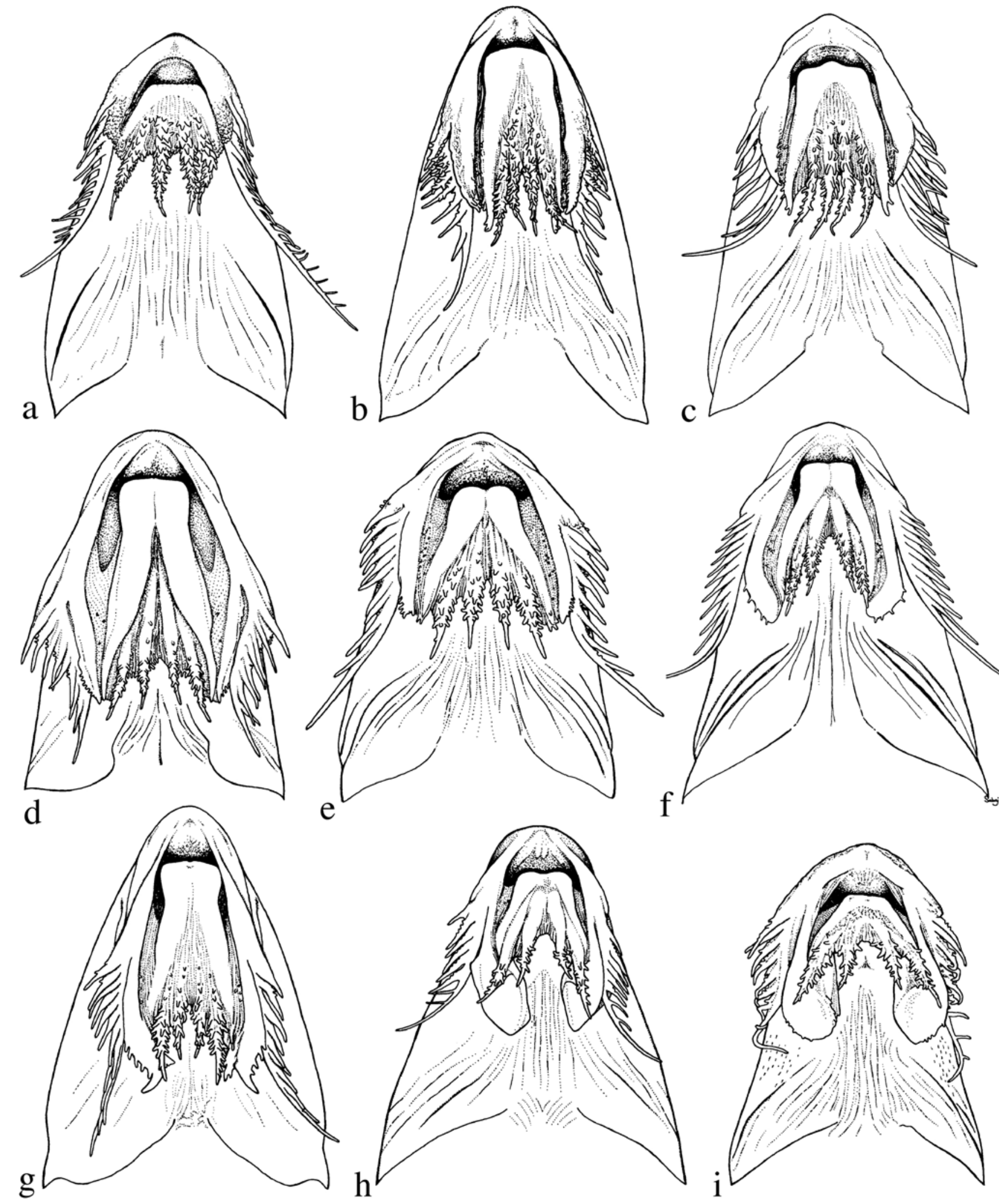

Fig. 4. Variation in oral-hood morphology in Anduzedoras and Leptodoras. a. A. oxyrhynchus, ANSP 160628 (SL 124.6 mm). b. L. praelongus, ANSP 162464 (SL 124.9 mm). c. L. copei, ANSP 162461 (SL 95.9 mm). d. L. hasemani, ANSP 175889 (SL 86.7 mm). e. L. linnelli, ANSP 175883 (SL 94 mm). f. L. nelsoni, MCNG 13167 (SL 93 mm). g. L. cataniai, ANSP 161533 (SL 162.5 mm). h. L. juruensis, INHS 39465 (SL 117.4 mm). i. L. myersi, ANSP 112319 (SL 72.6 mm). 


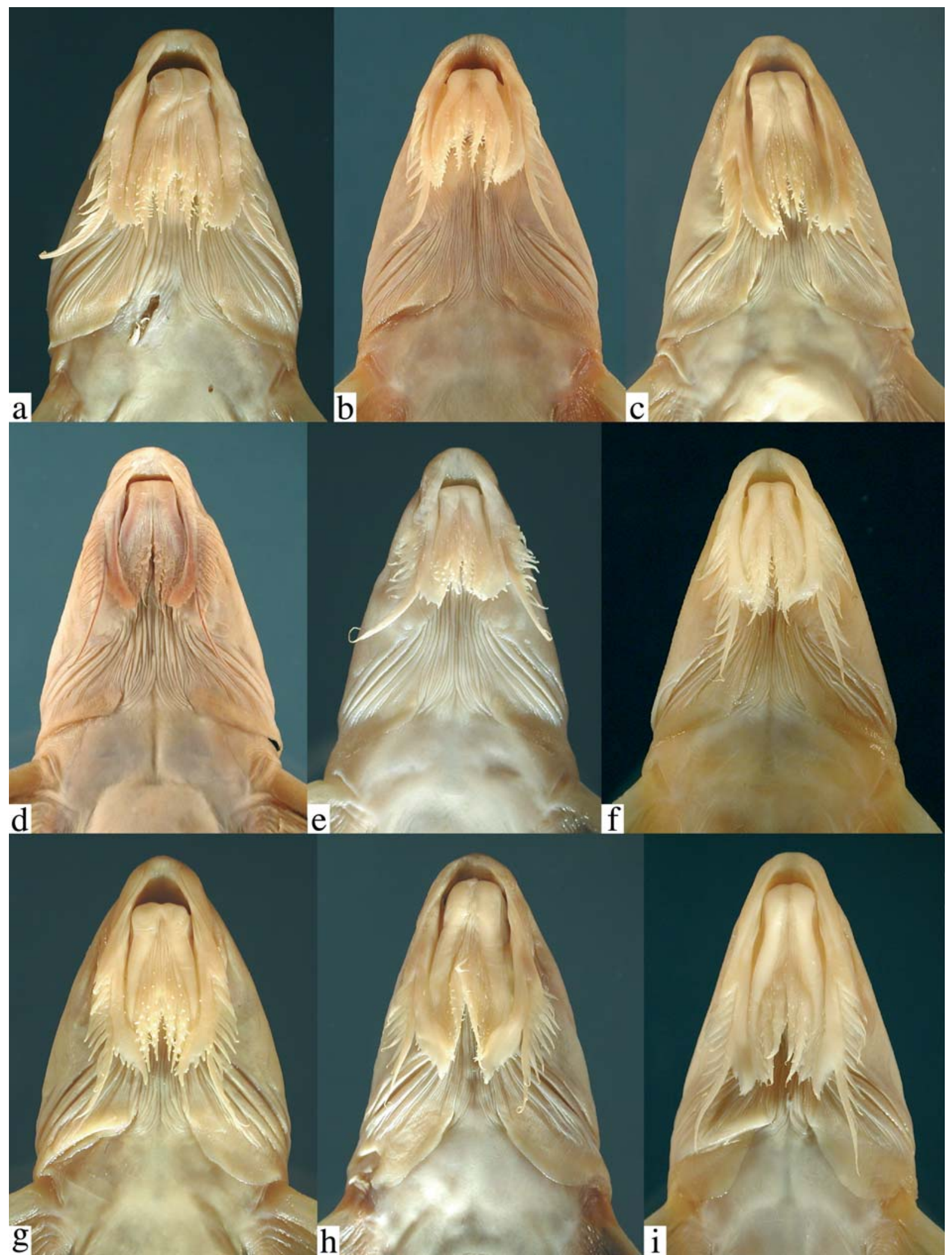

Fig. 5. Ventral views of heads in Leptodoras. a. L. linnelli, MBUCV-V 16602 (SL 157 mm). b. L. nelsoni, MBUCV-V 14769 (SL $135.8 \mathrm{~mm}$ ). c. L. rogersae, USNM 226307 (SL 180 mm). d. L. acipenserinus, FMNH 92385 (SL 155 mm). e. L. acipenserinus, FMNH 97140 (SL 113.3 mm). f. L. acipenserinus, ANSP 178467 (SL 107.9 mm). g. L. cataniai, ANSP 161532 (SL 142.6 mm). h. $L$. cf. cataniai Amazon form, ANSP 180925 (SL 194 mm). i. L. cf. cataniai Nanay form, ANSP 178438 (SL 164.2 mm). 
flap-like extensions (Figs. 4b-i, 5). These extensions are variously united by a thin and weakly papillate interlabial membrane. A thin membrane also joins the medial margin of lower labial extension to the outer jaw barbel. The lateral margin of upper labial extension is free from maxillary barbel and its origin roughly coincides with that of anteriormost $2^{\circ}$ maxillary barbel. In all Leptodoras except $L$. praelongus and $L$. cope $i$, the dorsalmedial surface of the lower labial extension is joined to a membranous fold (dorsolabial membrane, Fig. 1b) that originates on ventrolateral corner of snout posterior to base of maxillary barbel. Higuchi (1992:220) also considered the oral hood to be uniquely derived among Leptodoras.

In Leptodoras enlarged accessory lamellae (each appearing as a column of soft lappets) occur along the medial face of the first gill arch and extend well onto the medial face of the gill filaments (Fig. 6). In some Leptodoras (cataniai, juruensis, myersi), smaller accessory lamellae extend well onto the lateral face of the gill filaments and the gill rakers are absent or inconspicuous (Fig. 6b). Higuchi (1992:221) previously noted the morphology of the first gill arch as diagnostic of Leptodoras.

In Leptodoras the gas bladder has a modified cordiform shape and is reduced in overall size (i.e., shortened in particular; width greater than or equal to length) (Fig. 7). Furthermore, in all Leptodoras there are: two distinct and relatively large horn-like diverticula that project from the posterior wall of the gas bladder, and discrete pairs of bulbous diverticula that project from the anterolateral walls on either side. The uniqueness of gas-bladder morphology in Leptodoras was first suggested by Eigenmann (1925).

Comparisons. The oral hood in Leptodoras is most closely approximated among other doradids by Anduzedoras oxyrhynchus (Valenciennes) (Fig. 4a). In this monotypic genus the labial skin extends posteriorly beyond the corners of the mouth as flap-like structures united by an interlabial membrane. However, the labial extensions are relatively short and thickened, their ventral surfaces are rugose and papillate ( $v s$. relatively smooth in Leptodoras), and the interlabial mem-

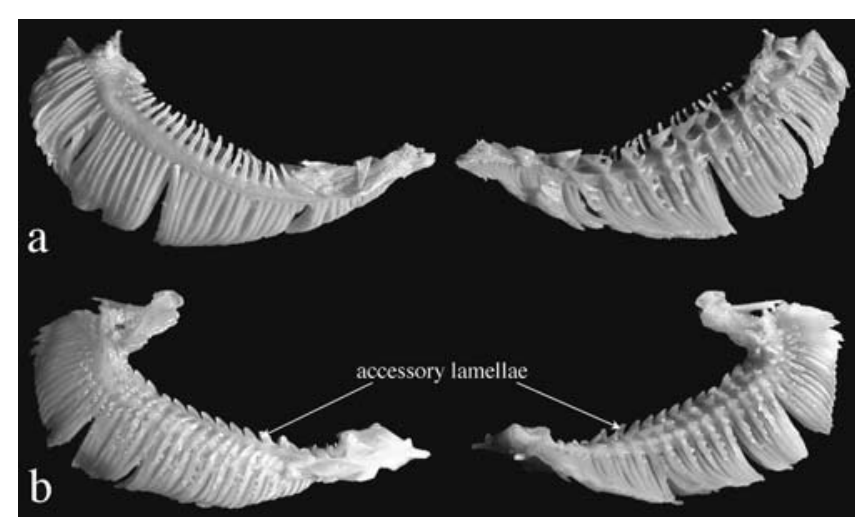

Fig. 6. Lateral (left) and medial (right) views of 1st gill arch. a. Leptodoras copei, ANSP 162466 (SL 141.5 mm). b. Leptodoras cataniai, ANSP 161532 (SL 148 mm). brane is relatively thick with numerous papillae ( $v s$. thin and few papillae in Leptodoras). Some authors have suggested that the labial extensions (the upper in particular) are derived from the barbels (e.g., Günther 1868b:230; Boulenger 1898:478, Eigenmann 1925:357; Böhlke 1970:57). Based on their formation in Leptodoras and related taxa these structures appear to be modifications of the labial skin as indicated by Higuchi (1992:220).

The accessory lamellae on the gill arches in Leptodoras resemble to those of certain other doradids (e.g., Doras, Anduzedoras, Hassar, Hemidoras). However, in these taxa the accessory lamellae are restricted to the medial face of the gill arch itself and do not extend onto the gill filaments.

In most other doradids the gas bladder is relatively large and often has an elongate cordiform shape. Other fimbriate-

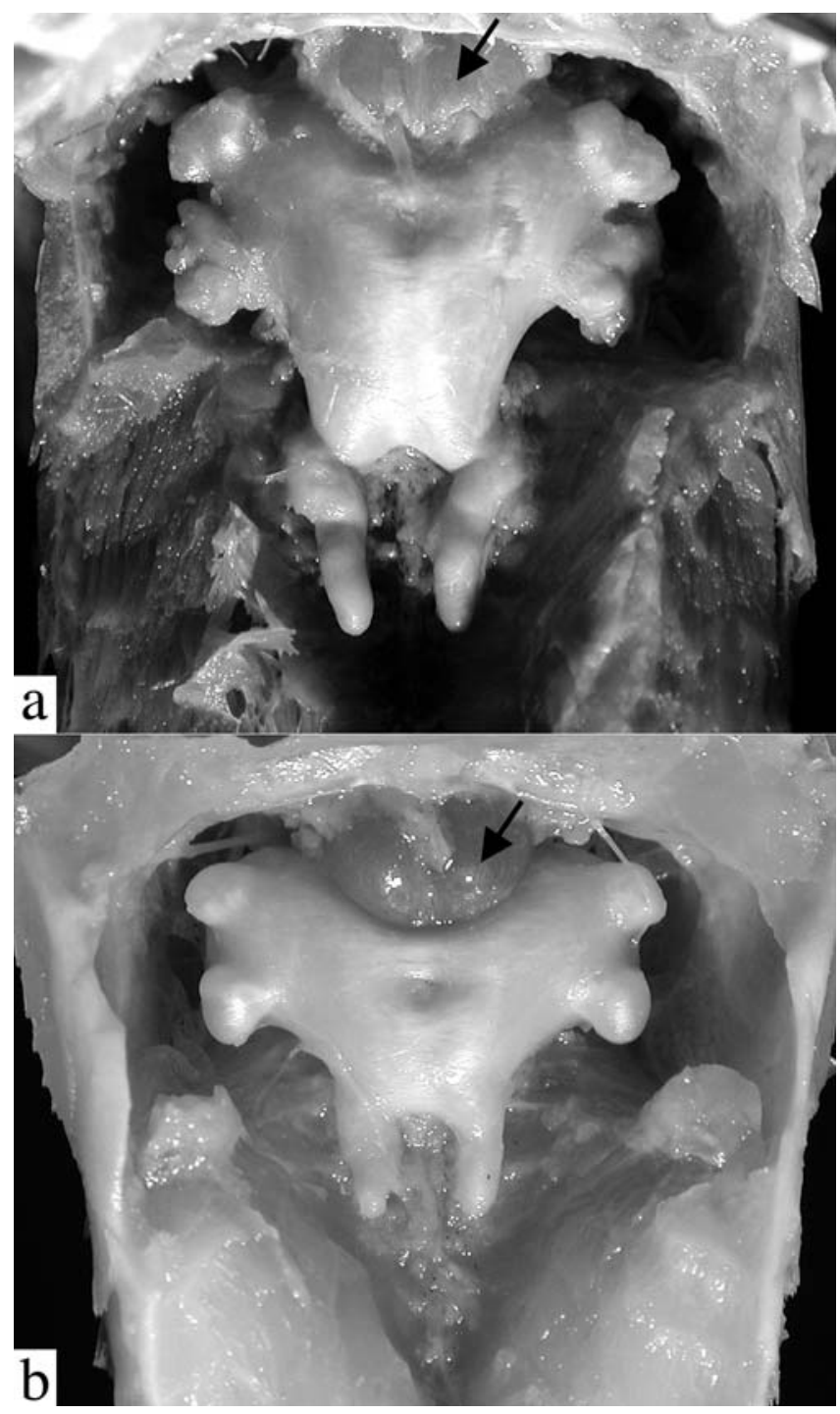

Fig. 7. Ventral views of gas bladders in situ (arrows denote bony capsules of enlarged first vertebra). a. Leptodoras praelongus, ANSP 162463 (SL $142 \mathrm{~mm}$ ). b. Leptodoras cf. cataniai, Nanay form, INHS 39814 (SL $111.1 \mathrm{~mm}$ ). 
barbel doradids have a single medial posterior diverticula that may be simple (e.g., Doras carinatus), split into two fingerlike projections joined at the base (e.g., Trachydoras), or ornamented with small bulbous swellings or thin finger-like projections (e.g., Anduzedoras, Hassar). Also unlike Leptodoras, the anterolateral walls of the gas bladder in other fimbriatebarbel doradids are smooth (e.g., Doras) or variously ornamented with many bulbous (e.g., Anduzedoras) or finger-like (e.g., Hassar, Hemidoras) diverticula. Rhynchodoras (genus with simple barbels) also has a reduced gas bladder and one species ( $R$. woodsi) has two posterior horn-like diverticula. However, in $R$. woodsi the lateral walls of the anterior chambers are smooth (vs. with a pair of bulbous diverticula in Leptodoras).

\section{Key to the species of Leptodoras.}

1. Distal half of dorsal fin with distinct black spot or blotch Leptodoras hasemani [p.653]

1'. Distal half of dorsal fin without black spot or blotch ........ 2

2. Dorsal spine thin and greatly extended as long flexible filament; predorsal distance relatively short, $26-28 \%$ of SL; bases of dorsal and paired fins with intense black pigment

Leptodoras juruensis [p.671]

2 '. Dorsal spine rarely extended as a long flexible filament; predorsal distance longer, $\geq 30 \%$ of SL; pigmentation on bases of dorsal and paired fins variable .

3. Broad dusky nuchal saddle extending ventrally across tympanum and humeral process, finishing on the lower side level with insertions of paired fins .......... Leptodoras myersi [p.675]

3'. No dark nuchal saddle and bar on side of body ................. 4

4. Flap-like posterior extensions at corners of lower lip narrow and long, finishing beyond tips of similar extensions at corners of upper lip (Figs. 4b,c); black melanophores concentrated on basal portions of dorsal spine and, sometimes, fin; sum of midlateral plates usually $<75$ (range 70-76) ....... 5

4'. Flap-like posterior extensions at corners of lower lip relatively short, finishing even with or before tips of similar extensions of upper lip (Figs. 4e-g); base of dorsal fin without intense black pigmentation (may appear dusky, but never black); sum of midlateral plates usually $\geq 75$ (range 74-92).

5. Anterior midlateral plates shallow, height of $2 \mathrm{nd}$ midlateral plate less than or equal to vertical diameter of eye; anterior nuchal plate usually narrow, permitting suture between supraoccipital and middle nuchal plate; profile of snout weakly concave ................. Leptodoras praelongus [p.647]

5 '. Anterior midlateral plates deeper, height of 2 nd midlateral plate distinctly greater than vertical diameter of eye; anterior nuchal plate usually expanded laterally and sutured to epioccipital; profile of snout rounded (convex)

Leptodoras copei [p.649]

6. Upper labial extension relatively long with narrow base and expanded distal portion that curves medially and has a distinctly pointed or triangular-shaped tip (Fig. 4g); dorsolabial membrane well-developed, widely rounded posteriorly; postcleithral (humeral) process relatively short, usually 19.3-28.5 times into SL, and dorsal margin often obscured by overlying skin ....................................... 7

6'. Upper labial extension (excluding small fimbriae) with rounded or truncate distal tip (Figs. 4e,f); dorsolabial membrane weakly to moderately developed, evenly attenuate posteriorly; postcleithral (humeral) process longer, 13.919.2 times into SL, and usually with well-defined margins

7. Adipose eye relatively large, horizontal length $1.5-1.8$ times into postorbital distance and $23.1-27.8 \%$ of predorsal distance; blackwaters of Negro and Casiquiare .

Leptodoras cataniai $[\mathrm{p} .667]$

7'. Adipose eye smaller, horizontal length 1.8-2.3 times into postorbital distance and $18-23.2 \%$ of predorsal distance; white to moderately blackwaters of Amazon basin .......... 8

8. Snout relatively long, length 1-1.2 times postorbital distance, $42.4-46.6 \%$ of predorsal distance; sum of midlateral plates $79-86$ (modally 82 ).

Leptodoras cf. cataniai (Nanay form) [p.670]

8'. Snout shorter, length 0.8-1 times postorbital distance, 37.6$41.3 \%$ of predorsal distance; sum of midlateral plates 83 92 (modally 88 )

Leptodoras cf. cataniai (Amazon form) [p.669]

9. Adipose eye relatively large, horizontal length $20.3-24.8 \%$ of predorsal distance and 11.2-13.9 times into SL; predorsal distance relatively long, $35.5-38.7 \%$ of SL; thin low preadipose ridge always present ............................................. 10

9'. Adipose eye smaller, horizontal length $15.4-19.1 \%$ of predorsal distance and 14.5-20.6 times into SL; predorsal distance somewhat shorter, $31.6-35.6 \%$ of SL; preadipose ridge absent or only weakly developed ............................ 11

10. Postorbital length $37.6-41.8 \%$ of predorsal distance ............. Leptodoras linnelli [p.654]

$10^{\prime}$. Postorbital length $42.9-44.6 \%$ of predorsal distance ............ . Leptodoras rogersae [p.665]

11. Postorbital distance 1.8-2 times distance from snout tip to anterior nares; snout length $37.8-41.8 \%$ of predorsal distance; anterior midlateral plates comparatively shallow, covering between $1 / 4$ and $1 / 2$ of corresponding body depth; sum of midlateral plates 82-86 (modally 84); Orinoco basin ..................................... Leptodoras rogersae [p.665]

11'. Postorbital distance 1.2-1.8 times distance from snout tip to anterior nares; snout length $41.6-46.5 \%$ of predorsal distance; anterior midlateral plates deep, covering half or more of corresponding body depth; sum of midlateral plates 74-86; Orinoco and Amazon basins ...................... 12

12. Thin low middorsal ridge of adipose tissue extending from adipose fin to point midway between anterior base of adipose fin and posterior base of dorsal fin; upper Amazon basin .......................... Leptodoras acipenserinus [p.658]

$12^{\prime}$. Preadipose ridge absent or only weakly developed, falling well short of point midway between anterior base of adipose fin and posterior base of dorsal fin; Orinoco ba-

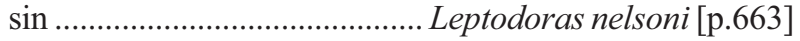




\section{Leptodoras praelongus (Myers \& Weitzman, 1956)}

Figs. $4 \mathrm{~b}, 7 \mathrm{a}$ and 8

Hassar praelongus Myers \& Weitzman 1956: 2, fig. 1 (type locality: São Gabriel Rapids of the rio Negro (Amazonas dr.), Amazonas, Brazil).

Diagnosis. Uniquely distinguished among Leptodoras by shal- low midlateral plates covering $\leq 1 / 4$ body depth $(v s .>1 / 4$ in all other species), and anterior nuchal plate usually of moderate width (longer than wide) permitting weak to firm suture between supraoccipital and middle nuchal plate (vs. anterior nuchal plate laterally expanded, sharing broad suture with epioccipital or forming dorsal border of nuchal foramina). Also distinguished from all Leptodoras except $L$. copei by having distal tip of lower labial extension extending beyond that of upper labial extension.

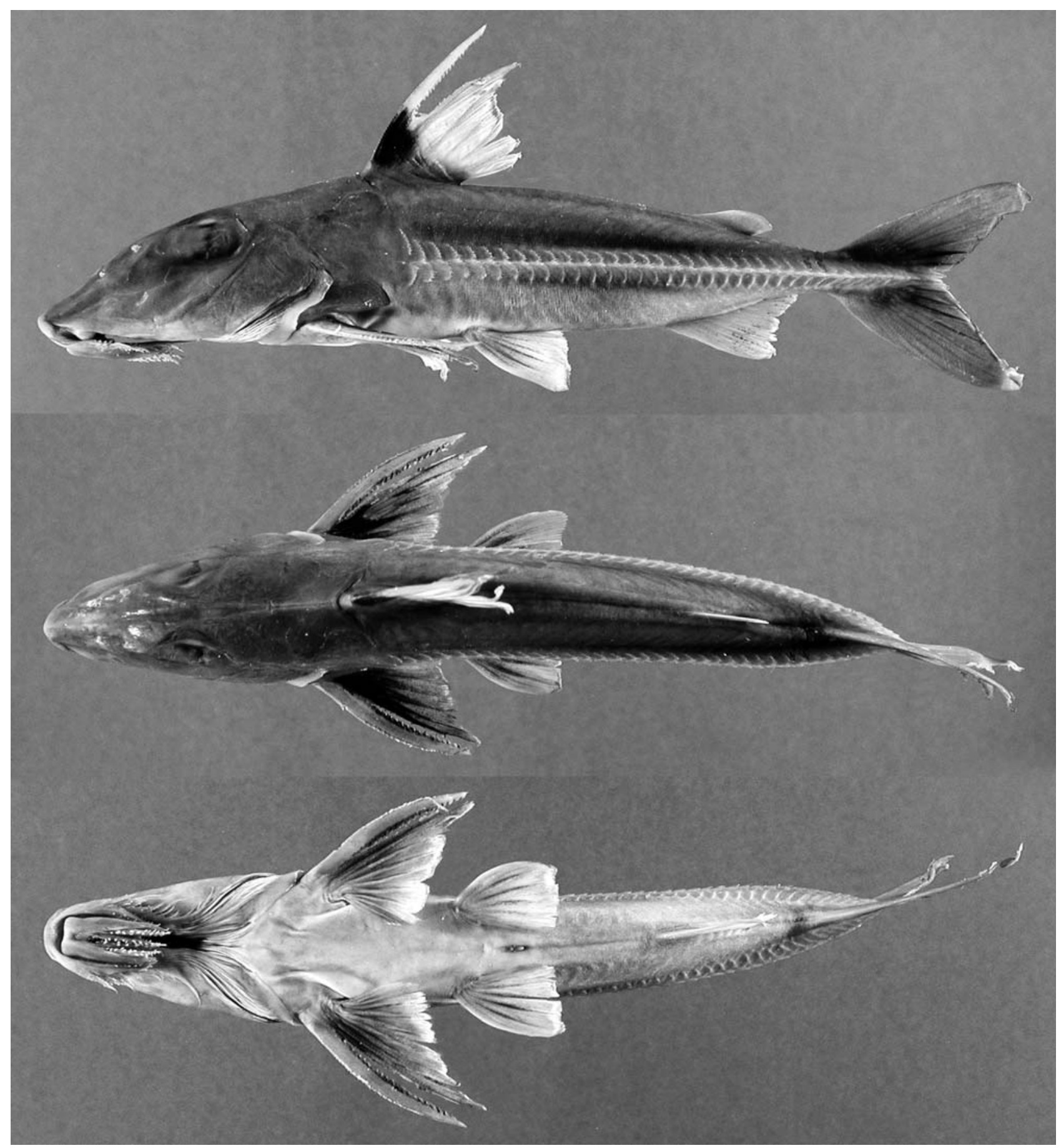

Fig. 8. Leptodoras praelongus, MBUCV-V 25602 (SL $151 \mathrm{~mm}$ ), río Canucunuma (Orinoco dr.), $40 \mathrm{~km}$ upstream from the mouth, Amazonas, Venezuela. 
Table 3. Frequency distribution of sum of midlateral plates in Leptodoras (modal numbers in squares; count begins with infranuchal plate).

\begin{tabular}{|c|c|c|c|c|c|c|c|c|c|c|c|c|c|c|c|c|c|c|c|c|c|c|c|c|c|}
\hline & 70 & 71 & 72 & 73 & 74 & 75 & 76 & 77 & 78 & 79 & 80 & 81 & 82 & 83 & 84 & 85 & 86 & 87 & 88 & 89 & 90 & 91 & 92 & Mean & $n$ \\
\hline Leptodoras praelongus & 2 & 2 & 5 & 3 & 5 & 3 & 1 & & & & & & & & & & & & & & & & & 73 & 21 \\
\hline Leptodoras copei & 1 & 5 & 7 & 1 & 1 & & & & & & & & & & & & & & & & & & & 71.7 & 15 \\
\hline Leptodoras hasemani & & & & & & 1 & 3 & 4 & 11 & 4 & 2 & & & & & & & & & & & & & 77.8 & 25 \\
\hline Leptodoras linnelli & & & & & 2 & 3 & 29 & 12 & 18 & 13 & 6 & 4 & & & & & & & & & & & & 77.4 & 87 \\
\hline Guianas, NE Brazil & & & & & 2 & 3 & 27 & 12 & 10 & 2 & 3 & & & & & & & & & & & & & 76.7 & 59 \\
\hline Upper Orinoco & & & & & & & 2 & & 8 & 11 & 3 & 4 & & & & & & & & & & & & 78.9 & 28 \\
\hline Leptodoras nelsoni & & & & & 1 & 5 & 4 & 8 & 9 & 7 & 1 & & & & & & & & & & & & & 77.3 & 35 \\
\hline Leptodoras rogersae & & & & & & & & & & & & & 6 & 8 & 8 & 6 & 2 & & & & & & & 83.7 & 30 \\
\hline Leptodoras acipenserinus & & & & & & & & 1 & 4 & 8 & 3 & 1 & 13 & 5 & 3 & & 1 & & & & & & & 81.1 & 39 \\
\hline Madeira, Itaya, Nanay & & & & & & & & 1 & 4 & 8 & 2 & 1 & 1 & & & & & & & & & & & 79.1 & 17 \\
\hline Marañon, Ucayali, Napo & & & & & & & & & & & 1 & & 12 & 5 & 3 & & 1 & & & & & & & 82.6 & 22 \\
\hline Leptodoras cataniai \& cf. ca & inia & & & & & & & & & 2 & 3 & 3 & 13 & 14 & 16 & 6 & 7 & 3 & 5 & 3 & 4 & & 2 & 84.4 & 81 \\
\hline cataniai & & & & & & & & & & & & & 4 & 7 & 10 & 4 & 4 & 2 & & & & & & 84.1 & 31 \\
\hline Amazon form & & & & & & & & & & & & & & 1 & & 2 & 2 & 1 & 5 & 3 & 4 & & 2 & 88.2 & 20 \\
\hline Nanay form & & & & & & & & & & 2 & 3 & 3 & 9 & 6 & 6 & & 1 & & & & & & & 82.2 & 30 \\
\hline Leptodoras juruensis & & & & & & & & & & & & & & & & & & & & 1 & 7 & 3 & & 90.2 & 11 \\
\hline Leptodoras myersi & & & & & 3 & 2 & 3 & 1 & 1 & 1 & & & & & & & & & & & & & & 75.8 & 11 \\
\hline
\end{tabular}

Description. Overall shape (excluding caudal fin) lenticular, weakly compressed, ventrally flattened from snout to vent; head deep with prominent conical snout; body elongate, caudal peduncle short, depressed. Eye large with well-developed adipose eyelid.

Mouth subterminal, jaws edentulous in adults, juveniles $<55 \mathrm{~mm}$ SL often with one or two small acicular teeth on distal-medial surface of each dentary (aside symphysis). Maxillary barbel of moderate length, usually finishing short of ventromedial extent of gill opening. Secondary maxillary barbels 7-10 (modally 9), flattened, largely overlapping; proximal secondary maxillary barbels with fimbriate anterior and posterior margins; distal ones smooth. Upper labial extension lanceolate (tapered distally), moderately elongate, comparatively thick, straight to weakly curved medially, ventral surface smooth or weakly rugose (sometimes with small papillae medially), lateral margin scalloped or with triangular fimbriae distally. Lower labial extension long (extends beyond upper labial extension), narrow, attenuate and straight; medial margin and tip with small papillae or fimbriae. Interlabial membrane of moderate width, slightly expanded distally (labial extensions divergent), comparatively thin with small papillae and free distal margin. Dorsolabial membrane absent. Two pairs of jaw barbels well-ornamented with elongate papillae and cojoined by basal membrane; outer pair only slightly longer than inner pair, shorter than maxillary barbel, and cojoined with lower labial extension via narrow membrane. Branchiostegal membrane with thin fleshy margin moderately overlapping ventral gill opening; fleshy inner flap along anteroventral face of cleithrum incomplete, not reaching cleithral notch for pectoral spine insertion. First gill arch with 15-20 moderately developed gill rakers (length about 4 times width); accessory lamellae on medial face of arch continuing well onto medial face of gill filaments (present on every third or fourth filament); each accessory lamella appears as a column of lappets with first one (opposite rakers) enlarged and deflected medially; accessory lamellae absent on lateral faces of gill arch and filaments.

Sum of midlateral plates 70-76 (modally 72 or 74 , Table 3 ). Anterior midlateral plates shallow, covering less than $1 / 4$ of corresponding body depth; posterior margins of dorsal and ventral wings rounded with small serrae. Tympanum without superficial ossifications or occasionally with 1 to 3 very small, weak spines along postotic laterosensory canal. Postcleithral process of moderate length and nearly uniform width, somewhat trapezoidal in shape. Middorsal groove on nuchal shield weakly defined. Nuchal foramina absent. Skin relatively smooth.

Dorsal-fin rays I,6; pectoral-fin rays I,8-10 (modally 9); pelvic-fin rays i,6; total anal-fin rays 14-15 (first 4 or 5 unbranched); caudal-fin rays i,8/9,i; dorsal procurrent caudalfin rays 14-17, ventral procurrent caudal-fin rays 13-16. Dorsal-fin spine long, moderate width, weakly curved and evenly attenuate with slender distal tip; anterior denticulations antrorse, small and crowded basally, absent from distal quarter; posterior denticulations retrorse, separated and well formed nearly to tip. Pectoral-fin spine sturdy, of moderate length, gently bowed with sharp tip; anterior denticulations antrorse, small and absent from distal quarter; posterior denticulations retrorse, decreasing in size from midlength to tip; last posterior denticulation subterminal. Pelvic fin short with straight distal margin. Anal fin triangular, tip of longest branched ray more or less even with vertical through base of last ray, distal margin shallowly concave. Caudal fin forked with rounded to weakly pointed lobes.

Coloration in alcohol. Head and body weakly countershaded, upper sides relatively uniform tan or gray-brown, lower sides (below midlateral plates) occasionally dusky with scattered melanophores (particularly in juveniles wherein the depigmented midlateral plates form white midlateral stripe), undersurfaces white to cream. Melanophores sometimes weakly concentrated in skin between and above dorsal wings of midlateral plates, effecting appearance of faint dusky stripe. 
Dorsal fin with large sub-basal black blotch on dorsal spine, first fin ray and intervening membrane; blotch often expanded posteriorly as dark wedge-shaped band across entire base of fin. Pectoral fin with melanophores concentrated along base and forming radiate streaks on distal membranes (fin rays relatively depigmented). Pelvic fin occasionally with similar but lighter pattern (fewer melanophores). Anal fin cream, hyaline, occasionally with few scattered melanophores. Caudal fin with melanophores forming black streaks on lower membranes of upper lobe and upper membranes of lower lobe, remaining portion cream, hyaline.

Distribution and habitat. Leptodoras praelongus is known from Brazil and Venezuela in the upper río Orinoco (upstream of Puerto Ayacucho), rio Negro, rio Tocantins, several localities along the rio Amazonas (between the rios Jutaí and Madeira), and one site in the Madeira basin (Fig. 9). Many collecting sites are associated with large river cataracts. Most records are from blackwaters. However, a few are from whitewater rivers (e.g., rios Branco and Madeira), and one is from a clearwater river (rio Tocantins).

Type-material examined. Leptodoras praelongus: holotype (unique), CAS 148679 [ex. SU 48679] (1, 112.25 mm), rio Negro, Amazonas dr., São Gabriel rapids, Amazonas, Brazil, 1 Feb 1925, C. Ternetz.

Non-type material. Brazil: Amazonas: ANSP 178538 (1), rio Madeira (Amazonas dr.), $9 \mathrm{~km}$ upstream from Vila Urucarituba (3³5’28"S, 5856’53"W), 6 Aug 1996, CCF-96-78; ANSP 180908 (3), rio Jutaí (Solimões dr.), between Pto. Antunes and Foz do Jutaí (250’6"S, 6655’39"W), 13 Nov 1993, JPS-93-049; ANSP 180909 (1), rio Jutaí (Solimões dr.), between Pto. Antunes and Foz do Jutaí (249’39"S, 6654'55"W), 13 Nov 1993, OTO-93-033; ANSP 180910 (3), rio Negro (Amazonas dr.), $37.8 \mathrm{~km}$ upstream from

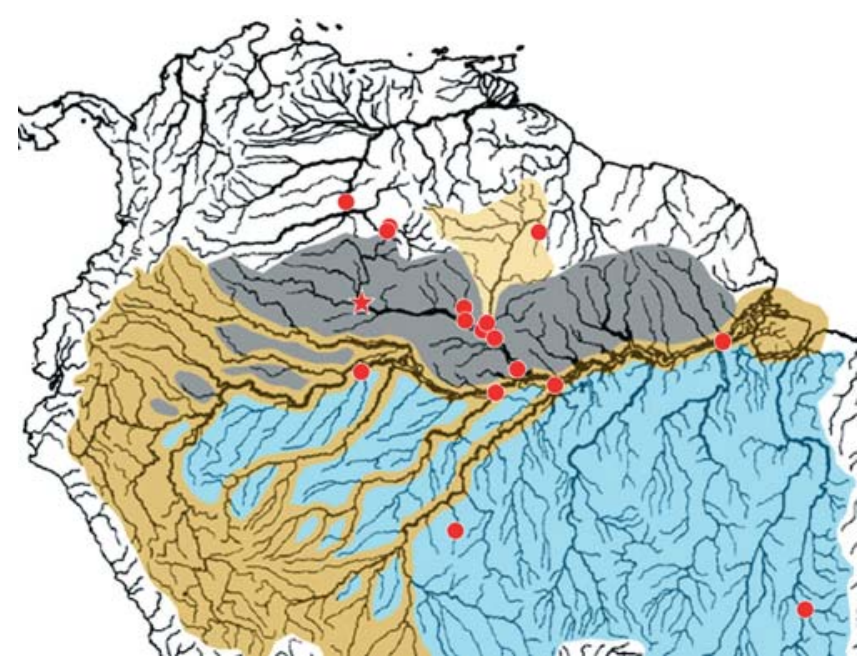

Fig. 9. Distribution of Leptodoras praelongus (star denotes type locality). Color overlays approximate water conditions as moderate to extreme blackwaters (gray), sediment-rich whitewaters (brown), mixed black/whitewaters (tan) and predominantly clearwaters (blue). Drainage base map by M. Weitzman.
Carvoeiro ( $\left.1^{\circ} 12^{\prime} 27^{\prime \prime S}, 62^{\circ} 15^{\prime} 3^{\prime \prime} \mathrm{W}\right), 10$ Dec 1993, MG-93-037; ANSP 180911 (2), rio Negro (Amazonas dr.), $10 \mathrm{~km}$ downstream from Carvoeiro (122'8"S, 6154'22"W), 9 Dec 1993, JGL-93190; ANSP 180912 (3), rio Negro (Amazonas dr.), 3.8 km downstream from S. Francisco (141'10"S, 6127'3"W), 6 Dec 1993, JPF-93-158; ANSP 180913 (1, $40.2 \mathrm{~mm}$ ), rio Negro (Amazonas dr.), 5 miles downstream from Santa Maria ( $\left.3^{\circ} 0^{\prime} 49^{\prime \prime} \mathrm{S}, 60^{\circ} 24^{\prime} 31^{\prime \prime} \mathrm{W}\right)$, 18 Jul 1996, MTP-96-007; ANSP 180916 (1), rio Jutaí (Solimões dr.), downstream of Pto. Antunes and upstream of Copatana (256’52"S, 6700’32"W), 16 Nov 1993, OTO-93-057; INPA ex. 17709 (4), rio Demini (Negro dr.), near mouth of rio Aracá, 22 Jun 1993; INPA 17727 (15), rio Negro (Amazonas dr.), near mouth of rio Branco, 13 Nov 1996; INPA 17761 (1, $112.1 \mathrm{~mm})$, INPA 17764 (3, 65.6-158 mm), rio Negro (Amazonas dr.), igarapé Zamula, near Barcelos, 19 Nov 1996; INPA 17907 (1, 111.1 mm), rio Negro (Amazonas dr.), at mouth of rio Branco, 4 Feb 1998. Para: ANSP 180914 (2), rio Amazonas (Atlantic dr.), $24 \mathrm{~km}$ upstream from Gurupa, $6 \mathrm{~km}$ downstream of mouth of rio Xingu (1 ${ }^{\circ} 28^{\prime} 12^{\prime \prime} \mathrm{S}$, 5149’43"W), 14 Nov 1994, AMZ-94-100. Rondônia: INPA uncataloged (3, 156-185 mm), rio Jamari (Madeira dr.), at and a little upstream of Ariquemes, downstream of mouth of rio Camaã, 15 Nov 1983. Roraima: ANSP 178534 (1), rio Branco (Negro dr.), between Atauba and Caruna, $9.3 \mathrm{~km}$ above confluence with rio Negro (1¹9’34"S, 6152'13"W), 8 Dec 1993, JGL-93-171; ANSP 180915 (3), rio Branco (Negro dr.), downstream of Atauba and upstream of Caruna (1 $\left.{ }^{\circ} 17^{\prime} 55^{\prime \prime} \mathrm{S}, 61^{\circ} 51^{\prime} 21^{\prime \prime W}\right), 8$ Dec 1993, JGL93-174; INPA 2004 (1, 147.3 mm), rio Tacutu (Branco dr.), 17 Mar 1988; USNM 332438 (2), rio Branco (Negro dr.), 25 Sep 1992. Tocantins: UNT 153 [ex. 3080] (1), rio Tocantins (Atlantic dr.), fazenda Traçadal, near Paranã City (12 $29^{\prime}$ S, $\left.48^{\circ} 12^{\prime} \mathrm{W}\right), 3$ Oct 2000. Venezuela: Amazonas: ANSP 162463 (3, 141.4-173 mm), río Pamoni (Casiquiare dr.), ca. $0.5 \mathrm{~km}$ from confluence with Casiquiare ( $\left.{ }^{\circ} 49^{\prime} \mathrm{N}, 65^{\circ} 55^{\prime} \mathrm{W}\right), 18-19$ Mar 1987, V87-34; ANSP 162464 (4, 120.24-127.9 mm), río Casiquiare, main channel, ca. $1.5 \mathrm{hrs}$ from its confluence with Orinoco ( $\left.3^{\circ} 5^{\prime} \mathrm{N}, 65^{\circ} 55^{\prime} \mathrm{W}\right), 16$ Mar 1987, V87-24; ANSP 162465 (3, 118-166.8 mm), río Casiquiare, from mouth of río Pamoni to $4 \mathrm{~km}$ below ( $\left.2^{\circ} 48^{\prime} \mathrm{N}, 65^{\circ} 57^{\prime} \mathrm{W}\right), 17$ Mar 1987, V8727; ANSP 165791 (1, $31.25 \mathrm{~mm}$ ), río Sipapo (Orinoco dr.), along playas of sand and rock ca. $1-4 \mathrm{~km}$ above Pendare $\left(4^{\circ} 51^{\prime} \mathrm{N}\right.$, 6744'W), 12 Nov 1985, V85-8; ANSP 165793 (6, 34.76-49.2 mm), río Sipapo (Orinoco dr.), ca. 3-4 km upstream from Pendare $\left(4^{\circ} 52^{\prime} \mathrm{N}\right.$, 674’ 'W), 12 Nov 1985, V85-5; MBUCV-V 25602 (1, 151.0 mm), río Canucunuma (Orinoco Dr.), desde campamento $2 \mathrm{~km}$ rio abajo, 40 km sobre boca en río Orinoco, 23 Mar 1987; MBUCV-V 25603 (2), río Casiquiare, canal principal ca. $1.5 \mathrm{hrs}$ des de boca en río Orinoco, ca. $1 \mathrm{hr}$ rio abajo, 23 Mar 1987; MBUCV-V 25664 (1, $134.7 \mathrm{~mm}$ ), same data as ANSP 162465.

\section{Leptodoras copei (Fernández-Yépez, 1968)}

Figs. 4c, 6a and 10

Anduzedoras copei Fernández-Yépez 1968: 31, fig. 10 (type locality: río Capanaparo, Orinoco dr., Apure, Venezuela).

Diagnosis. Uniquely distinguished among Leptodoras by the following combination: anterior nuchal plate usually wide (laterally expanded) and sharing broad suture with epioccipital, nuchal foramina absent, distal tip of lower labial extension reaching beyond that of upper labial extension, anterior midlateral plates moderately deep (covering a little more than 
$1 / 3$ of body depth), and pectoral-fin spine short, not reaching anterior origin of pelvic fin when depressed.

Comparisons. Among Leptodoras, only L. hasemani also has a laterally expanded anterior nuchal plate with no nuchal foramina and it is distinguished by having a dark black blotch in distal half of dorsal fin ( $v s$. absent in L. copei). Leptodoras praelongus also has a long lower labial extension, but is distinguished by having a narrower anterior nuchal plate (supraoccipital usually sharing suture with middle nuchal plate vs. like suture absent in copei), shallower anterior plates (cov- ering at most $1 / 4$ of body depth $v s .1 / 3$ in copei), and longer pectoral-fin spine (reaching or extending beyond anterior origin of pelvic fin when depressed $v s$. falling short of pelvic-fin origin in copei).

Description. Somewhat torpedo-shaped; body elongate, nearly symmetrical in cross-section, predorsal region bluntly cone-shaped, caudal peduncle short, depressed. Eye large with well-developed adipose eyelid.

Mouth subterminal, jaws edentulous in adults and juveniles as small as $31 \mathrm{~mm}$ SL. Maxillary barbel of moderate length,

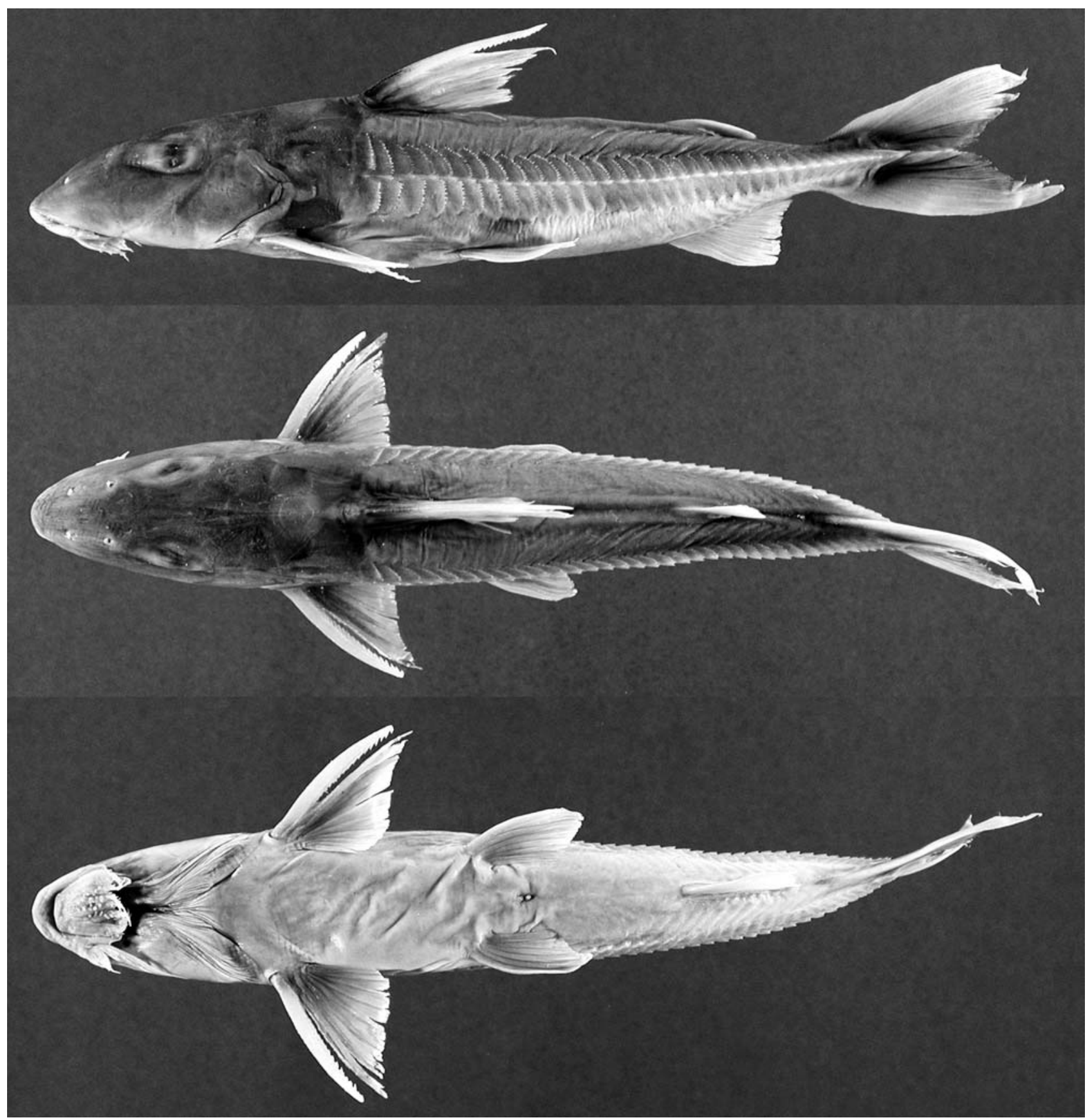

Fig. 10. Leptodoras copei, ANSP 162466 (SL $141.5 \mathrm{~mm}$ ), río Orinoco (Atlantic dr.), near mouth of río Iguapo, Amazonas, Venezuela. 
finishing short of ventromedial extent of gill opening. Secondary maxillary barbels 7-10 (modally 8), flattened, largely overlapping; proximal secondary maxillary barbels with fimbriate anterior margins; distal ones smooth. Remaining features of buccal hood very similar to L. praelongus except lateral margin of upper labial extension entire or weakly scalloped. Branchiostegal flap and morphology of first gill arch also as in L. praelongus.

Sum of midlateral plates 70-74 (modally 72, Table 3). Anterior midlateral plates of moderate depth, covering slightly more than $1 / 3$ of corresponding body depth; posterior margins of dorsal and ventral wings rounded with small serrae. Tympanum usually with 3 small ossifications (plates or weak spines) along postotic laterosensory canal; small fixed spine usually visible along posterior margin of neurocranium where postotic laterosensory canal exits supracleithrum. Postcleithral process short to moderate in length, nearly uniform width or slightly expanded posteriorly. Middorsal groove on nuchal shield weakly defined. Nuchal foramina absent. Skin sometimes with very small fleshy papillae scattered over snout and dorsolateral flanks; papillae on snout variously cojoined to form irregular longitudinal ridges especially in juveniles $(<100 \mathrm{~mm} \mathrm{SL})$.

Dorsal-fin rays I,6; pectoral-fin rays I,8-9 (modally 9); pelvic-fin rays i,6; total anal-fin rays 13-16 (first 4 or 5 unbranched); caudal-fin rays i,8/9,i; dorsal procurrent caudalfin rays 16-19, ventral procurrent caudal-fin rays 15-17. Dorsal-fin spine of moderate length, slender and weakly curved for much of length with short, sharp divergent tip; anterior denticulations antrorse, very small, crowded basally, largely absent from distal half; posterior denticulations retrorse, small but regularly spaced nearly to tip. Pectoral-fin spine sturdy, short, gently bowed with sharp tip; anterior denticulations antrorse, very small, absent from distal third; posterior denticulations retrorse, gradually decreasing in size from midlength to tip; last posterior denticulation subterminal. Pelvic fin of moderate length, rounded to weakly pointed. Anal fin triangular, tip of longest branched ray more or less even with vertical through base of last ray, distal margin shallowly concave. Caudal fin forked with rounded to weakly pointed lobes.

Coloration in alcohol. Similar to L. praelongus except lower sides more often depigmented. Head and body weakly countershaded, upper sides relatively uniform tan or graybrown, lower and ventral surfaces white to cream. Base of dorsal spine with black anterior margin and dusky sides, remaining dorsal fin usually depigmented except for scattered melanophores on skin covering insertion. Pectoral fin with faint concentration of melanophores along base forming light streaks on distal membranes. Pelvic, anal and paired fins cream, hyaline. Caudal fin with melanophores forming black streaks on lower membranes of upper lobe and upper membranes of lower lobe, remaining fin cream. Juveniles often with two dusky blotches on base of caudal fin, one above and one below midlateral plates (blotches overlie aforementioned streaks).
Specimens from the rio Amazonas (all juveniles, hereafter referred to as Leptodoras cf. copei) exhibit a color pattern distinguishable from that typical of juvenile $L$. copei from the rios Negro and Orinoco. In Amazon specimens the base of the dorsal fin is rather darkly pigmented and the dorsolateral sides beneath the dorsal and adipose fins are often dusky with scattered melanophores. In dorsal view, these markings appear as a pair of opposing chevrons.

Distribution and habitat. Leptodoras copei sensu lato is known from the upper río Orinoco, rio Negro and río Amazonas in Venezuela, Brazil and Peru (Fig. 11). Most collections are from large river habitats in the upper río Orinoco, rio Negro and the mouths of their larger tributaries. Leptodoras copei was described on the basis of a juvenile from the río Capanaparo, tributary to the middle Orinoco. Another collection of small juveniles is from a downstream site on the Orinoco near the mouth of the río Caura.

Specimens examined from the rio Amazonas are all juveniles, but may represent (based on color pattern) an undescribed species related to L. copei. Santos et al. (1984:52) figured (as Doras cf. lipophthalmus) a specimen from the lower rio Tocantins, Brazil (not mapped in Fig. 11), that may represent an adult of the Amazon species or yet another undescribed species related to $L$. copei.

Type-material examined. Anduzedoras copei: holotype, FMNH 84069 [ex. AFY 51.311] (65.6 mm), laguna al lado del río Capanaparo (Orinoco dr.), Apure, Venezuela, 22 Mar 1951, A. Fernández-Yépez.

Non-type material. L. copei: Brazil: CAS 158891 [ex. SU 58891] (3), rio Negro (Amazonas dr.), Cucuhy (= Cucuí), Colombian border, 14 Feb 1925. Amazonas: ANSP 180892 (1), rio Negro (Amazonas dr.), $12.6 \mathrm{~km}$ downstream from Moura (1³0’47.2"S, 61³2'19.4"W), 7 Dec 1993, MG-93-033; ANSP 180893 (5), rio Negro (Amazonas dr.), between S. Francisco and S. Francisco de Assis (147’20.6"S, 61²4’44.4"W), 6 Dec 1993, JGL-93-163; ANSP 180896 (1), rio Negro (Amazonas dr.), $3.8 \mathrm{~km}$ downstream from S. Francisco, $47.2 \mathrm{~km}$ upstream from S. Francisco de Assis (141’37"S, 61²6’50"W), 6 Dec 1993, JPF-93-158. Roraima: ANSP 180894 (2), rio Branco (Negro dr.), downstream of Atauba and upstream of Caruna (1¹7'55"S, 61 $\left.{ }^{\circ} 51^{\prime} 21^{\prime \prime W}\right), 8$ Dec 1993, JGL-

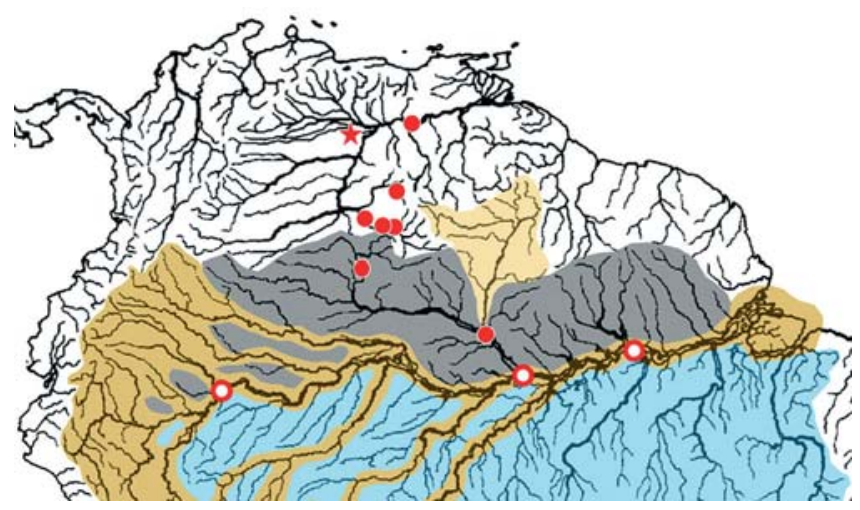

Fig. 11. Distributions of Leptodoras copei (solid circles, star denotes type locality) and $L$. cf. copei (open circles). 
93-174. Venezuela: Amazonas: ANSP 162461 (3, 61.3-95.9 mm), río Orinoco (Atlantic dr.), near mouth of caño Yaguae $\left(3^{\circ} 33^{\prime} \mathrm{N}\right.$, 66² 'W), 24 Mar 1987, V87-47; ANSP 162466 (1, $141.46 \mathrm{~mm})$, MBUCV-V 25616 (1, $129.9 \mathrm{~mm}$ ), río Orinoco (Atlantic dr.), near mouth of río Iguapo $\left(3^{\circ} 07^{\prime} \mathrm{N}, 65^{\circ} 28^{\prime} \mathrm{W}\right), 14$ Mar 1987, V87-14; CAS 158896 [ex. SU 58896] (2), río Orinoco (Atlantic dr.), playa de la boca del Casiquiare, bifurcation, 22 Mar 1925; ANSP 180901 (4), río Ventuari (Orinoco dr.), raudales Tencua, $56 \mathrm{~km}$ ESE of San Juan de Manapiare (5'2'59"N, 65'37’38"W), 19 Apr 2004, VEN 04-31. Bolivar: ANSP 177987 (3, 31-41 mm), río Orinoco (Atlantic dr.), beaches, canals, lagoons and islands in vicinity of Puerto Las Majadas, near confluence with río Caura $\left(7^{\circ} 38.6^{\prime} \mathrm{N}, 64^{\circ} 50^{\prime} \mathrm{W}\right), 23$

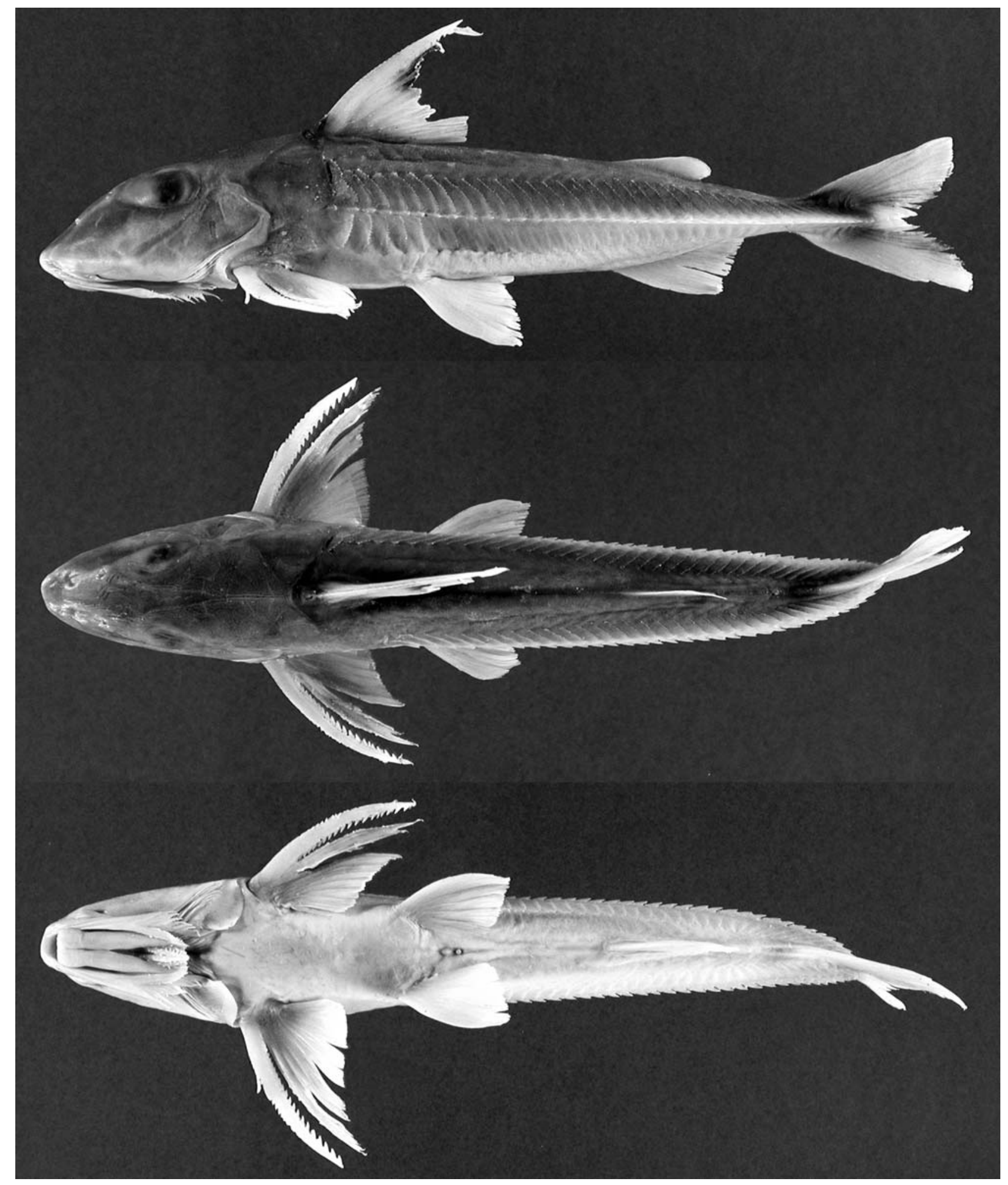

Fig. 12. Leptodoras hasemani, ANSP 175885 (SL 156.4 mm), Essequibo river (Atlantic dr.), Guyana. 
Nov 1985, V85-54. L. cf. copei: Brazil: Amazonas: ANSP 180895 (1), rio Solimões (Amazonas dr.), $62.8 \mathrm{~km}$ downstream from Bela Vista, $25 \mathrm{~km}$ upstream from Manaus ( $\left.3^{\circ} 12^{\prime} 08^{\prime \prime} \mathrm{S}, 59^{\circ} 53^{\prime} 42^{\prime \prime} \mathrm{W}\right), 24$ Oct 1993, JPF-93-011. Para: ANSP 178540 (1, $49.5 \mathrm{~mm})$, rio Amazonas (Atlantic dr.), $13.6 \mathrm{~km}$ downstream from Óbidos, 26.6 $\mathrm{km}$ below mouth of rio Trombetas (1 $\left.{ }^{\circ} 59^{\prime} 58.6^{\prime \prime} \mathrm{S}, 55^{\circ} 25^{\prime} 46.3^{\prime \prime} \mathrm{W}\right)$, 27 Oct 1994, JGL-94-081. Peru: Loreto: ANSP 149948 (1, 49.08 mm), ANSP 150185 (1, $42.08 \mathrm{~mm}$ ), río Amazonas (Atlantic dr.), vicinity of Iquitos, between Isla Iquitos and Isla Lapuna, near Lapuna shore, 9 Oct 1955, P55-9.

\section{Leptodoras hasemani (Steindachner, 1915)}

Figs. 4d and 12

Hemidoras hasemani Steindachner 1915: 218 (type locality: rio Branco, Negro dr., Boa Vista, Roraima, Brazil).

Diagnosis. Uniquely distinguished among Leptodoras by having a large black blotch in the distal half of the anterior dorsal-fin rays and membranes. Also in L. hasemani the basal portion of the lower labial extension is uniformly widened and flat compared to other Leptodoras.

Description. Body elongate, weakly compressed; head comparatively short, deep, weakly compressed with bluntly pointed snout; ventrally flattened from snout to vent; caudal peduncle moderately elongate, depressed. Eye large with welldeveloped adipose eyelid.

Mouth subterminal, jaws edentulous in adults and juveniles as small as $39 \mathrm{~mm}$ SL. Oral hood comparatively large and somewhat unique in that origins of first secondary maxillary barbels and upper labial extensions occur well beyond distal margin of dentary. Maxillary barbel long, usually reaching to or slightly beyond ventromedial extent of gill opening. Secondary maxillary barbels 6-9 (modally 7 or 8), flattened, largely overlapping; proximal secondary maxillary barbels with fimbriate anterior margin and smooth posterior margin; distal ones smooth. Upper labial extension lanceolate (tapered distally), moderately elongate, usually straight with smooth ventral surface; lateral margin with small distal fimbriae. Lower labial extension finishing more or less even with upper labial extension, basal portion uniformly broad with conspicuously smooth surface, distal portion narrow, attenuate; margins smooth. Interlabial membrane narrow to moderate width (labial extensions parallel or convergent), comparatively thin with few very small papillae. Dorsolabial membrane weakly developed, evenly attenuate posteriorly. Two pairs of jaw barbels with comparatively few elongate papillae and broadly cojoined by basal membrane; outer pair only slightly longer than inner pair and shorter than maxillary barbel, cojoined with lower labial extension via narrow membrane. Branchiostegal membrane with greatly expanded fleshy margin that strongly overlaps ventral gill opening; fleshy inner flap along cleithrum well developed, reaching cleithral notch for pectoral spine insertion. Morphology of first gill arch similar to L. praelongus and L. copei.
Sum of midlateral plates 75-80 (modally 78, Table 3 ). Anterior midlateral plates deep, covering more than half of corresponding body depth; posterior margins of dorsal and ventral wings rounded with many small serrae. Tympanum usually with 3 small ossifications (plates or weak spines) along postotic laterosensory canal; small fixed spine usually visible along posterior margin of neurocranium where postotic laterosensory canal exits supracleithrum. Postcleithral process short, nearly uniform width or slightly expanded posteriorly. Middorsal groove on nuchal shield weakly defined. Nuchal foramina absent. Skin comparatively smooth, sometimes with minute papillae on head in region between eyes and posterior nares.

Dorsal-fin rays I,6; pectoral-fin rays I,10-11 (modally 10); pelvic-fin rays i,6; total anal-fin rays 14-16 (first 4 to 6 unbranched); caudal-fin rays i,8/9,i; dorsal procurrent caudalfin rays 14-17, ventral procurrent caudal-fin rays 13-17. Dorsal-fin spine of moderate length, rather sturdy, weakly curved for much of length, becoming straight near sharp tip; anterior denticulations antrorse, small, crowded basally and largely absent from distal third; posterior denticulations retrorse, moderately sized and regularly spaced to tip. Pectoral-fin spine sturdy, long, distinctly bowed with sharp tip; anterior denticulations antrorse, rather small, largely absent from distal third; posterior denticulations strong, retrorse, size rather uniform from midlength to tip; last denticulation subterminal. Pelvic fin of moderate length, very weakly pointed. Anal fin triangular, tip of longest branched ray more or less even with base of last ray, distal margin nearly straight. Caudal fin forked with rounded to bluntly pointed lobes.

Coloration in alcohol. Head and body weakly countershaded, upper sides relatively uniform tan or light gray, lower sides and ventral surfaces white to cream. Distal half of soft dorsal fin with large black blotch; melanophores concentrated on first two rays and three inter-radial membranes; remaining fin hyaline. Melanophores concentrated on skin covering dorsal-locking spine and posterior margin of nuchal shield. Dorsal spine depigmented or with few melanophores along anterior margin. Pectoral fin with few melanophores scattered along base and inter-radial membranes, remaining portions cream. Pelvic fins and anal fin relatively depigmented, cream, hyaline. Caudal fin with melanophores forming parallel pair of faint dusky stripes, one on lower rays and membranes of upper lobe and other on upper rays and membranes of lower lobe (portions of stripe overlying membranes appear darker); remaining portions of caudal fin light by comparison with sparsely scattered melanophores, particularly on rays.

Distribution and habitat. Leptodoras hasemani is known from the río Orinoco, rio Branco (Negro dr.) and Essequibo river in Venezuela, Brazil and Guyana, respectively (Fig. 13). It also occurs in the lower rio Demini, a tributary of the rio Negro. This species appears to favor whitewater habitats. Collections are from the main channels of large rivers and often associated with large sandy beaches. 


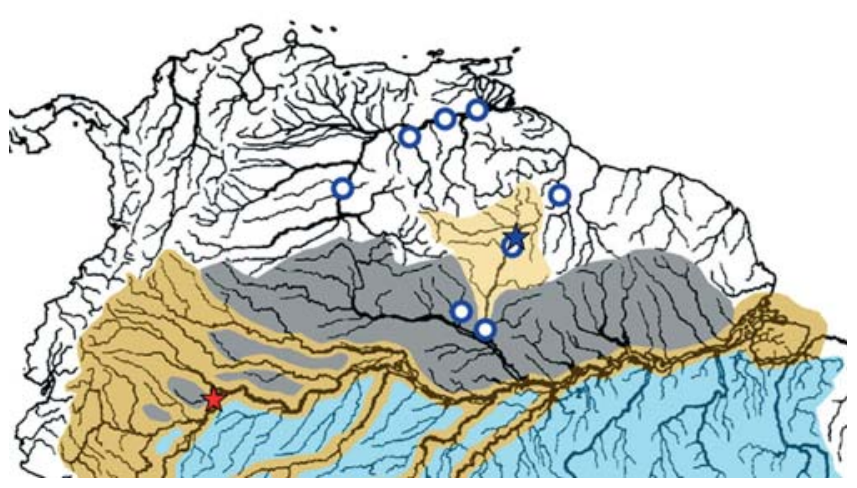

Fig. 13. Distributions of Leptodoras hasemani (open circles, blue star denotes type locality) and L. myersi (red star denotes type locality).

Type-material examined. Hemidoras hasemani: lectotype by present designation, NMW 46381 (82 mm, largest), rio Branco (Negro dr.), Boa Vista, Brazil, J. D. Haseman. Paralectotypes: NMW ex. 46381 (3, 77.2-80.1 mm), NMW 46382 (4, 73.1-80.5 $\mathrm{mm})$, same data as lectotype; NMW $46383(5,66.0-76.6 \mathrm{~mm})$, rio Branco (Negro dr.), Serra Grande, Brazil, J. D. Haseman; NMW 46384 (1, $46.9 \mathrm{~mm}$ ), rio Negro (Amazonas dr.), delta of río Negro, Brazil, J. D. Haseman (not this species and reidentified here as Hemidoras stenopeltis [Kner 1855]); NMW 46385 (1, 68.6), Conceição, below Boa Vista, Brazil, J. D. Haseman; NMW 46470 (3, 58.8-64.5 mm), same data as NMW 46383.

Non-type material. Brazil: Amazonas: INPA 17705 (12), rio Demini (Negro dr.), near mouth of rio Aracá, 21 Jun 1993. Roraima: ANSP 178533 (1), rio Branco, $9.3 \mathrm{~km}$ upstream from confluence with rio Negro, between Atauba and Caruna (1 ${ }^{\circ} 19^{\prime} 34$ "S, 6152'13"W), 8 Dec 1993, JGL-93-171. Guyana: ANSP 175884 (4, 89.0-167 mm), Essequibo River (Atlantic Dr.), sandbars in vicinity of Maipuri campsite (4³4'17"N, 58 $\left.35^{\circ} 17^{\prime \prime} \mathrm{W}\right), 31 \mathrm{Jan}$ 1997, WGS97-28; ANSP 175885 (1, $157 \mathrm{~mm}$ ), Essequibo river (Atlantic dr.), 180 yards upstream from Essequibo campsite (Maipuri) (445'43"N, 5845'52"W), 27 Jan 1997, WGS97-23; ANSP 175886 (5), Essequibo river (Atlantic dr.), Essequibo campsite (445'41"N, 5845'53"W), 26 Jan 1997, WGS97-19; ANSP 175887 (3), Essequibo river (Atlantic dr.), sandbars in

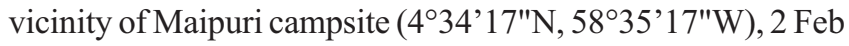
1997, WGS97-31; ANSP 175888 (4), same data as ANSP 175887; ANSP 175889 (1, $86.7 \mathrm{~mm}$ ), Essequibo river (Atlantic dr.), sandbar ca. $800 \mathrm{~m}$ downstream from Essequibo campsite (Maipuri) (445’43"N, 5845’52"W), 29 Jan 1997, WGS 97-25; ROM 62633 (43), Essequibo river (Atlantic dr.), at southern tip of Indian House Island just north of Kurupukari ( $\left.4^{\circ} 40^{\prime} 23^{\prime \prime} \mathrm{N}, 58^{\circ} 40^{\prime} 50^{\prime \prime} \mathrm{W}\right)$, 15 Oct 1990, H90-78; ROM 62643 (2), Essequibo river (Atlantic dr.), inlet and beach downstream from Kurupukari $\left(4^{\circ} 42^{\prime} 57^{\prime \prime} \mathrm{N}\right.$, $\left.58^{\circ} 42^{\prime} 40^{\prime \prime} \mathrm{W}\right), 10$ Oct 1990, H90-43. Venezuela: Amazonas: ANSP $165788(1,57.1 \mathrm{~mm}$ ), río Orinoco (Atlantic dr.), shores of Isla de Raton (5'05'N, 6748’W), 14 Nov 1985, V85-18; ANSP 180897 (2), río Orinoco (Atlantic dr.), island west of Puerto Venado, 4.5 $\mathrm{km}$ south of Samariapo, $56.5 \mathrm{~km} \mathrm{SW}$ of Puerto Ayacucho ( $\left.5^{\circ} 12^{\prime} 25^{\prime \prime N}, 67^{\circ} 48^{\prime} 32^{\prime \prime} \mathrm{W}\right), 28 \mathrm{Feb} 2005$, VEN 05-04. Bolivar:
FMNH $109976(2,76.8,152.5 \mathrm{~mm})$, río Caura (Orinoco dr.), sand island $1 \mathrm{~km}$ upstream from mouth of caño Mato $\left(7^{\circ} 11^{\prime} 49^{\prime \prime} \mathrm{N}\right.$, 65ㅇ'53"W), 9 Dec 2000; LACM 43011 (1), río Orinoco (Atlantic dr.), river channel between Palua and San Felix, 180 nautical miles upstream from sea buoy, 15 Feb 1978; MCNG 19239 (2, 39.2, $43.6 \mathrm{~mm}$ ), puente del río Orocopiche (Orinoco Dr.), near Ciudad Bolivar, 23 Sep 1988, ABD87-33.

\section{Leptodoras linnelli Eigenmann, 1912}

Figs. 4e, 5a, 14 and 15a,b

Leptodoras linnelli Eigenmann 1912:191, pl. 17 (fig. 1), pl. 18

(fig. 1) (type locality: Potaro river (Essequibo dr.) at Tumatumari, Mazaruni-Potaro, Guyana).

Diagnosis. Uniquely distinguished among Leptodoras by shape of upper labial extension: very elongate, straight to weakly curved medially, and nearly uniform in width with a bluntly rounded tip vs. moderately elongate and attenuate (in L. praelongus, copei, hasemani) or moderately to strongly curved and distal portion distinctly expanded with wide lateral flap (in L. acipenserinus, nelsoni, rogersae, cataniai, juruensis, myersi).

Leptodoras linnelli is further distinguished from all Leptodoras except $L$. acipenserinus by having an adipose fin that extends anteriorly as a low thin ridge to a point midway between the anterior insertion of the adipose fin and the posterior insertion of the dorsal fin. Leptodoras linnelli is distinguished from $L$. acipenserinus by a number of characters including a relatively longer predorsal distance (35.5-38.7\% SL vs. 31.6-35.6\% in acipenserinus), inner flap of gill opening incomplete ( $v s$. usually complete, nearly reaching cleithral notch in acipenserinus), lower sum of midlateral plates (7481 vs. 77-86 in acipenserinus), anal-fin shape (tip of longest branched ray falls short of vertical through tip of last branched ray in extended anal fin and is more or less even with vertical through base of last ray; line defined by tips angled anteriorly, forming a $45-90^{\circ}$ angle with long axis of body $v s$. tip of longest branched ray falls well short of base of last branched ray, line defined by tips sharply angled anteriorly, forming a $30-45^{\circ}$ angle with long axis of body in acipenserinus), pectoral-fin spine length (19.9-26.2\% of SL vs. $18.6-21.3 \%$ in acipenserinus) and pectoral-fin spine dentation (teeth strongly retrorse along majority of posterior margin, becoming less retrorse distally, size relatively uniform along distal half, last denticulation usually subterminal vs. teeth becoming gradually larger and less retrorse towards tip of spine, last and/or penultimate denticulation nearly perpendicular to long axis of spine, last denticulation terminal, its lateral margin continuous with tip of pectoral spine in acipenserinus).

Description. Morphometrics summarized in Table 1. Similar in shape to L. hasemani except head very weakly depressed, snout comparatively longer and more acute; caudal peduncle moderately elongate, depressed. Eye large but with weakly developed adipose eyelid. 
Mouth subterminal, jaws edentulous in adults and juveniles as small as $50 \mathrm{~mm}$ SL. Maxillary barbel long, usually reaching ventromedial extent of gill opening. Secondary maxillary barbels 7-11 (modally 10), flattened, largely overlapping; proximal secondary maxillary barbels with fimbriate anterior margin and smooth posterior margin; distal ones smooth.
Upper labial extension rather elongate, straight to weakly curved medially, width nearly uniform, tip bluntly rounded, ventral surface smooth, distal lateral margin weakly expanded and with small fimbriae. Lower labial extension narrow, attenuate, usually finishing even with or slightly beyond upper labial extension; margins smooth, distal tip often with few
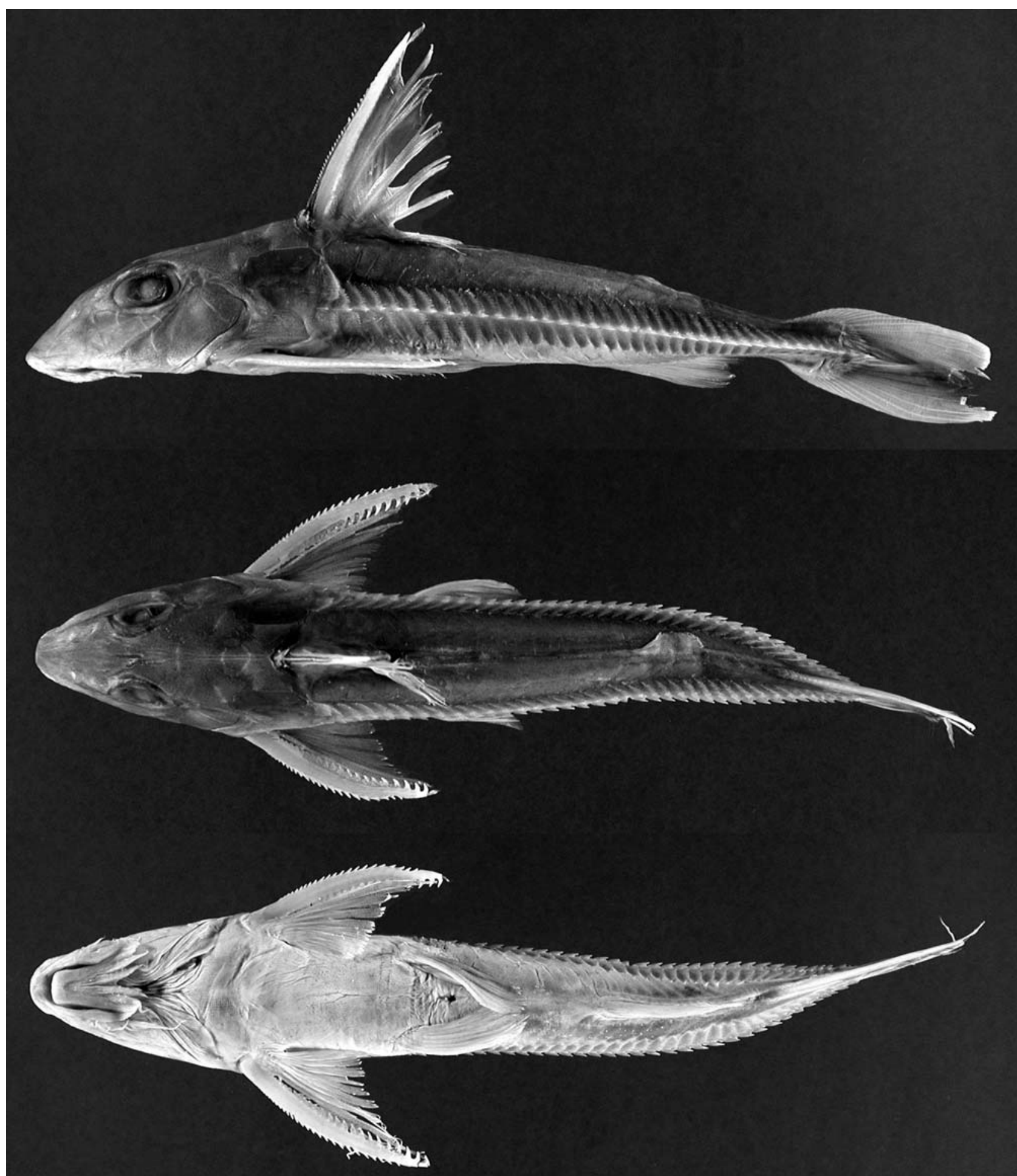

Fig. 14. Leptodoras linnelli, BMNH 1911.10.31:73-74 (SL 162.2 mm, paratype), Potaro river (Essequibo dr.) Tumatumari, Guyana. 
small papillae or fimbriae. Interlabial membrane of narrow to moderate width (labial extensions parallel or convergent), comparatively thin with few small papillae. Dorsolabial membrane weakly developed, evenly attenuate posteriorly. Two
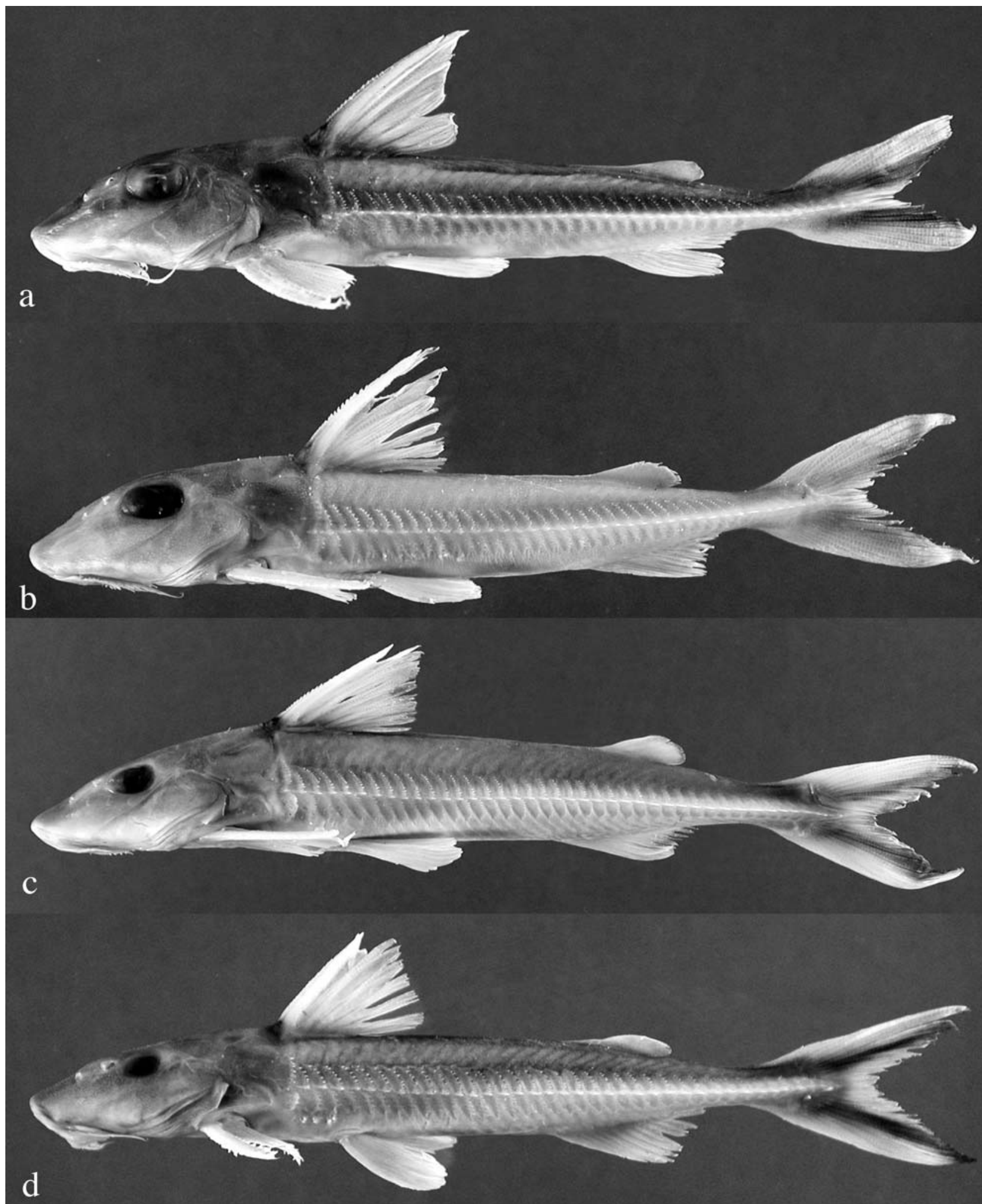

Fig. 15. Juvenile and subadult Leptodoras (Orinoco and Essequibo basins). a. L. linnelli, ANSP 175881 (SL $100.1 \mathrm{~mm}$ ), Essequibo river, Guyana. b. L. linnelli, MBUCV-V 19689 (SL 100.5 mm), río Mavaca (Orinoco dr.), Amazonas, Venezuela. c. $L$. rogersae, paratype, MBUCV-V 13372 (SL 128.8 mm), río Orinoco, Delta Amacuro, Venezuela. d. L. nelsoni, paratype, MBUCVV 14769 (SL 104.5 mm), río Apure, Apure, Venezuela. 
pairs of jaw barbels with scattered elongate papillae; cojoined by basal membrane; outer pair slightly longer than inner pair and shorter than maxillary barbel, cojoined with lower labial extension via narrow membrane. Branchiostegal membrane with moderately expanded fleshy margin overlapping ventral gill opening; fleshy inner flap along cleithrum incomplete, not reaching cleithral notch for pectoral spine insertion. First gill arch with 15-20 weakly developed gill rakers (length about 2-3 times width); accessory lamellae on medial face of arch and continue well onto medial face of gill filaments (present on every second or third filament); each accessory lamella appears as a column of lappets with first one (opposite rakers) enlarged and deflected medially; accessory lamellae absent or only very weakly developed on lateral faces of gill arch and filaments (may appear as one or few small lappets near base of filaments).

Sum of midlateral plates 74-81 (modally 76, Table 3). Anterior midlateral plates moderately deep, covering about half of corresponding body depth; posterior margins of dorsal and ventral wings rounded with many small serrae. Tympanum usually with 3 small ossifications (weak spines) along postotic laterosensory canal; small fixed spine usually visible along posterior margin of neurocranium where postotic laterosensory canal exits supracleithrum. Postcleithral process short, deep and slightly expanded posteriorly. Middorsal groove on nuchal shield usually well-defined. Nuchal foramina present as small lenticular opening partially or wholly replacing suture between anterior nuchal plate and epioccipital. Skin relatively smooth in adults; juveniles with few, very small papillae on snout and upper head not forming distinct ridges.

Dorsal-fin rays I,6; pectoral-fin rays I,9-10 (modally 10); pelvic-fin rays i,6; total anal-fin rays 12-16 (first 4 to 6 unbranched); caudal-fin rays i,8/9,i; dorsal procurrent caudalfin rays 14-19, ventral procurrent caudal-fin rays 13-17. Dorsal-fin spine of moderate length, sturdy, nearly straight (rarely weakly angled) and evenly attenuate with sharp tip; anterior denticulations antrorse, moderately sized and evenly spaced basally, largely absent from distal third; posterior denticulations small, retrorse basally, becoming straight and more spaced distally, present nearly to tip. Pectoral-fin spine sturdy, long, weakly bowed with blunt tip; anterior denticulations antrorse, moderately sized nearly to tip; posterior denticulations strongly retrorse along most of posterior margin, becoming less retrorse distally, moderately sized and relatively uniform along distal half; last denticulation usually subterminal. Pelvic fin of moderate length, rounded. Anal fin triangular, tip of longest branched ray more or less even with vertical through base of last anal fin ray, distal margin nearly straight or very shallowly concave. Caudal fin forked with rounded or weakly pointed lobes.

Coloration in alcohol. Head and body coloration similar to $L$. hasemani; weakly countershaded, upper sides somewhat uniform tan or light gray, occasionally darker brown (Brazilian specimens). Wide dusky middorsal stripe evident in some specimens, flanked by lighter areas along upper sides. Melanophores sometimes weakly concentrated in skin between and above dorsal wings of midlateral plates, effecting appearance of faint dusky stripe. Lower sides and ventral surfaces white to cream.

Dorsal, anal and paired fins without distinct markings. Dorsal fin with faint stippling on rays and skin covering insertion; darker stippling concentrated along anterior margin of dorsal spine and around perimeter of locking spine. Pectoral and pelvic fins cream to white with faint stippling on dorsal surfaces. Anal fin cream, hyaline. Caudal fin with parallel pair of dusky stripes as in L. hasemani.

Distribution and habitat. Leptodoras linnelli is known from the upper río Orinoco (ríos Ventuari and Mavaca) and a tributary of the Casiquiare (río Siapa), Venezuela; Atlantic Coast drainages of the Guianas and northern Brazil (e.g., Essequibo, Demerara, Araguari); and the rios Uatumã (Amazonas dr.), Tacutu (Branco dr.) and lower Demini (Negro dr.), Brazil (Fig. 16). The distribution of $L$. linnelli appears to be restricted to river systems draining the Guiana Shield. Most collections are from whitewater or turbid rivers, often in places with sandy beaches and swift currents (e.g., cataracts).

Type-material examined. Leptodoras linnelli: holotype, FMNH 53561 [ex. CM 1626a] (153.5 mm), Potaro river (Essequibo dr.), Tumatumari, Guyana, 1908, C.H. Eigenmann et al. Paratypes (33 of 36, 3 missing): Guyana: BMNH 1911.10.31.73-74 [ex. CM 1627a-e, ex. IU 12022] (1+1*, 162.2 $\mathrm{mm}$ ), same data as holotype; BMNH 1911.10.31.75 [ex. CM 1627a-e, ex. IU 12022, Tumatumari or ex. CM 1629a, ex. IU 12023, Crab Falls] (1, 70.9 mm), Potaro river (Essequibo dr.), Tumatumari or Essequibo river (Atlantic dr.), Crab Falls, 1908, C.H. Eigenmann et al.; CAS 59775 [ex. CM 1627a-e, ex. IU 12022] (5, 52.1-173.5 mm), same data as holotype; CAS 59776

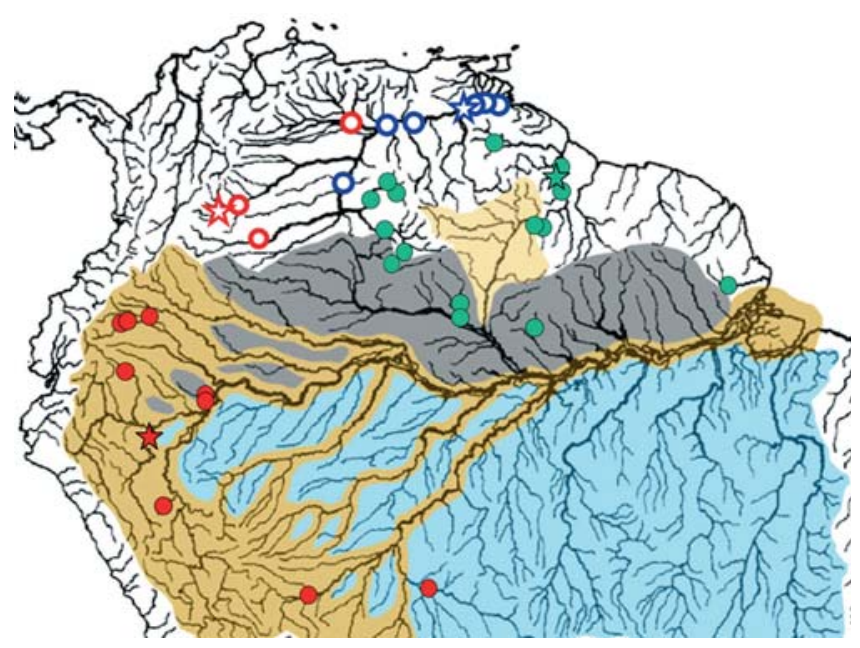

Fig. 16. Distributions of Leptodoras acipenserinus (solid red circles), L. linnelli (solid green circles), L. nelsoni (open red circles) and $L$. rogersae (open blue circles) (stars denote type localities). 
[ex. CM 1629a, ex. IU 12023] (2, 59.28, 86.45 mm), Essequibo river (Atlantic Dr.), Crab Falls, 1908, C. H. Eigenmann et al.; CAS 59777 [ex. CM 1628, ex. IU 12024] (1, 51.9 mm), Essequibo River (Atlantic Dr.), Rockstone, 1908, C. H. Eigenmann et al.; CAS 121940 [ex. SU 21940, ex. CM 1627a-e, ex. IU 12022] (1*, $169 \mathrm{~mm}$ ), same data as holotype; FMNH 7399 [ex. CM 1627ae, ex. IU 12022] (1, 168.0 mm), FMNH 53186 [ex. CM 1627a-e, ex. IU 12022] (12, 48.9-161.0 mm), same data as holotype; FMNH 53187 [ex. CM 1628a, ex. IU 12024] (1, $145.1 \mathrm{~mm})$, same data as CAS 59777; FMNH 53188 [ex. CM 1630] (1, 138.8 mm), Georgetown Market ?, 1908, C. H. Eigenmann et al.; FMNH 53562 [ex. CM 1629a, ex. IU 12023] (1, 69.0 mm), same data as CAS 59776; MCZ 30070 [ex. CM 1629a, ex. IU 12023] (1, 151.9 mm), same data as CAS 59776; MCZ 30071 [ex. CM 1627a-e, ex. IU 12022] ( $\left.1^{*}, 151.9 \mathrm{~mm}\right)$, same data as holotype; NMW 46109 [ex. CM 1627a-e, ex. IU 12022] (1, $145.4 \mathrm{~mm})$, same data as holotype; USNM 66222 ex. CM 1627a-e, ex. IU 12022 (1*, $144.2 \mathrm{~mm}$ ), same data as holotype; ZMA 110690 [ex. CM 1627ae, ex. IU 12022, Tumatumari or ex. CM 1629a, ex. IU 12023, Crab Falls] (1), same data as BMNH 1911.10.31.75.

Non-type material. Brazil: Amapá: INPA20969 (3, 149-178 mm), MNHN 1998-0168 (1+3*, 153-175.6 mm), rio Araguari (Atlantic dr.), cachoeira (waterfall) da Capivara, upstream of Porto Grande (5152’54.5"W, 1²’43.6"N), 19-22 Aug 1992. Amazonas: INPA ex. 17709 (1, $54 \mathrm{~mm}$ ), rio Demini (Negro dr.), near mouth of rio Aracá, 22 Jun 1993; INPA 17721 (1, 45 mm), rio Negro (Amazonas dr.), Barcelos, 6 Jul 1994; MNHN 1996$1122\left(1^{*}, 200.6 \mathrm{~mm}\right)$, rio Pitinga (Uatumã-Amazonas dr.), Cachoeira 40 ilhas, between Balbina and Pitinga reservoirs, about $15 \mathrm{~km}$ dowstream of the Pitinga dam, 1994. Roraima: INPA 2002 (11), rio Tacutu (Branco dr.), Bonfim, 17 Mar 1988. Guyana: AMNH 214846 (8), Demerara, 1934; AMNH 214913 (2), Demerara, 26 Nov -1 Dec, 1934; ANSP 39734 (1, 135.3 mm), Rupununi river (Essequibo dr.), 1911; ANSP 175880 (3+1*, $93.3 \mathrm{~mm}$ ), isolated stagnant pool/pond (Essequibo dr.), some $40 \mathrm{~min}$. from main Essequibo river channel $\left(4^{\circ} 32^{\prime} 43^{\prime \prime} \mathrm{N}\right.$, $\left.58^{\circ} 35^{\prime} 02^{\prime \prime} \mathrm{W}\right), 31$ Jan 1997, WGS 97-27; ANSP 175881 (3), Essequibo river (Atlantic dr.), sandbar ca. $800 \mathrm{~m}$ downstream from Essequibo campsite (Maipuri) $\left(4^{\circ} 45^{\prime} 43^{\prime \prime} \mathrm{N}, 58^{\circ} 45^{\prime} 52^{\prime \prime} \mathrm{W}\right)$, 29 Jan 1997, WGS 97-25; ANSP 175882 (1*, 84.8 mm), Essequibo river (Atlantic dr.), sandbars in vicinity of Maipuri campsite (4³4'17"N, 58³5'17"W), 2 Feb 1997, WGS 97-31; ANSP 175883 (1*, $94.2 \mathrm{~mm}$ ), Essequibo river (Atlantic dr.), Essequibo campsite (445'41"N, 5845'53"W), 26 Jan 1997, WGS 97-19; ANSP 177270 (8), Essequibo river (Atlantic dr.), extensive sandbar $2 \mathrm{~km}$ upstream from Paddle Rock campsite (442’20"N, 5842’26"W), 25 Nov 1997, GGW 97-23; ANSP 177271 (3), Essequibo river (Atlantic dr.), extensive sandbar $500 \mathrm{~m}$ downstream from Paddle Rock campsite $\left(4^{\circ} 44^{\prime} \mathrm{N}\right.$, 5843’W), 23 Nov 1997, GGW 97-17; ANSP 179177 (15), Takutu river (Branco dr.), ca. $2.75 \mathrm{~km}$ west of Saint Ignatius $\left(3^{\circ} 21^{\prime} 18^{\prime \prime} \mathrm{N}\right.$, 59॰49'51"W), 5 Nov 2002; AUM 27943 (8, 50.0-59.9 mm), Demerara River (Atlantic dr.), $5.05 \mathrm{mi} \mathrm{SSW}$ Linden, bearing $195^{\circ}\left(5^{\circ} 56^{\prime} \mathrm{N}, 58^{\circ} 18^{\prime} 22^{\prime \prime} \mathrm{W}\right), 17-18$ Oct 1998, Guy 98-6; INHS 49099 (9, 47.0-70.4 mm), same data as AUM 27943. Venezuela: Amazonas: AMNH $91373\left(1^{*}, 92.7 \mathrm{~mm}\right.$ ), río Mavaca (Orinoco dr.), near base camp at sand beach, 17 Mar 1989, CJF-AMA 89-21; AMNH 91374 (3 + 2*, 88.1-99.6 mm), río Mavaca (Orinoco dr.), $30 \mathrm{~min}$. upriver from base camp, at sand beach on right bank, 10 Mar 1989, CJF 89-10; ANSP 180817 (5), río Ventuari (Orinoco dr.), village of Marueta at landing, $91 \mathrm{~km}$ east-northeast of Macuruco, $159 \mathrm{~km}$ east-northeast of San Fernando de Atabapo (4 $\left.18^{\prime} 51^{\prime \prime} \mathrm{N}, 66^{\circ} 17^{\prime} 32^{\prime \prime} \mathrm{W}\right), 6$ Apr 2004, VEN 04-12; ANSP 180900 (3), río Manapiare and mouth of río Yutaje (Ventuari dr.), $14 \mathrm{~km}$ northwest of San Juan de Manapiare (5²6' $\left.12 " \mathrm{~N}, 66^{\circ} 6^{\prime} 45^{\prime \prime} \mathrm{W}\right), 13$ Apr 2004, VEN 04-25; ANSP 180902 (2), río Ventuari (Orinoco dr.), raudales Tencua, $56 \mathrm{~km}$ east-southeast of San Juan de Manapiare $\left(5^{\circ} 2^{\prime} 59^{\prime \prime} \mathrm{N}\right.$, 65³7’38"W), 19 Apr 2004, VEN 04-31; ANSP 180903 (2), río Siapa (Casiquiare dr.), raudale Gallineta, $142 \mathrm{~km}$ east of San Carlos de Río Negro (1 $\left.{ }^{\circ} 49^{\prime} \mathrm{N}, 65^{\circ} 47^{\prime} 41^{\prime \prime} \mathrm{W}\right), 17 \mathrm{Mar} 2005$, VEN 05-31; ANSP 180906 (3), río Ventuari (Orinoco dr.), beach at village of Moriche, $116 \mathrm{~km}$ northeast of Macuruco, $169 \mathrm{~km}$ northeast of San Fernando de Atabapo ( $\left.4^{\circ} 45^{\prime} \mathrm{N}, 66^{\circ} 21^{\prime} 13^{\prime \prime} \mathrm{W}\right)$, 7 Apr 2004, VEN 04-15; CAS 159157 [ex. SU 59157] (3+4*, 97.4-125 mm), río Casiquiare, beach at mouth of Casiquiare at Orinoco bifurcation, 22 Mar 1925; MBUCV-V 19288 (1*, 85.8 $\mathrm{mm}$ ), río Mavaca (Orinoco Dr.), playa arenosa, rio arriba de campamento, 8 Mar 1989; MBUCV-V 19404 (1*, 98.8 mm), same data as AMNH 91373; MBUCV-V 19689 (3*, 84.6-100 mm), same data as AMNH 91374. Bolivar: MBUCV-V 10210 (1,93.2 $\mathrm{mm}$ ), río Cuyuní (Essequibo dr.), isla de Jacobo, cerca del raudal de Kinotovaca, 26 Feb 1977; MBUCV-V $16529\left(1^{*}, 110.8\right.$ $\mathrm{mm}$ ), río Cuyuni (Essequibo dr.), $10 \mathrm{~km}$ oeste del $\mathrm{km} \mathrm{88,} \mathrm{via} \mathrm{El}$ Dorado-Luedpa, Ste. Elena de Vairen, 12 Apr 1987; MBUCV-V $16602\left(1+1^{*}, 157 \mathrm{~mm}\right)$, same data as MBUCV-V 16529.

\section{Leptodoras acipenserinus (Günther, 1868)}

Figs. 5d-f, 17, 18a,b and 19a

Oxydoras acipenserinus Günther 1868a: 475 (type locality: Xeberos (= Jeberos) near río Aipana, small tributary joining río Huallaga near the latter's confluence with río Marañon (Amazonas dr.), Loreto, Peru.

Diagnosis. Distinguished from all Leptodoras except $L$. linnelli by having adipose fin extended anteriorly as a low thin ridge of adipose tissue to a point midway between anterior insertion of adipose fin and posterior insertion of dorsal fin. See diagnosis of $L$. linnelli for characteristics distinguishing it from L. acipenserinus.

Description. Morphometrics summarized in Table 1. Body very elongate and dorsoventrally depressed, ventrally flattened from snout to vent; head also depressed, short relative to body with comparatively long acute snout; dorsal profile of snout shallowly convex from tip to midway between nares; caudal peduncle long, shallow. Eye moderately sized with weakly developed adipose eyelid.

Mouth subterminal, jaws edentulous in adults, small juveniles with few thin acicular teeth near medial symphysis of 
dentaries. Maxillary barbel long, usually reaching ventromedial extent of gill opening. Secondary maxillary barbels 9-12 (modally 11), flattened, overlapping proximally, separated distally; proximal secondary maxillary barbels with fimbriate anterior margin and smooth posterior margin; distal ones smooth.
Oral hood comparatively short overall, not greatly expanded posteriorly. Upper labial extension elongate, somewhat Lshaped, proximal half straight and narrow, distal half moderately to strongly curved medially and distinctly expanded with wide lateral flap bearing small fimbriae, surface smooth.

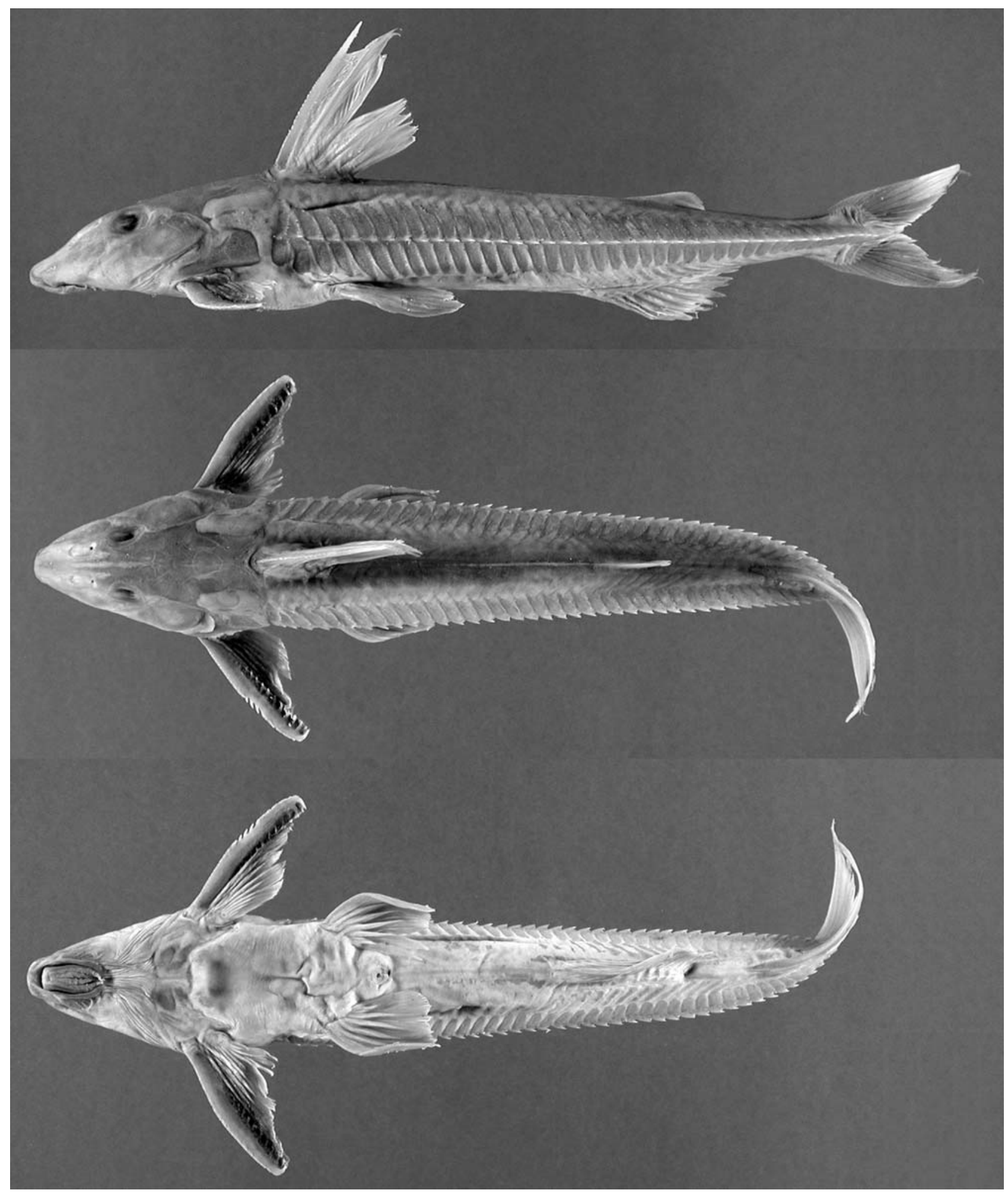

Fig. 17. Leptodoras acipenserinus, FMNH 92385 (SL 196.5 mm), río Bobonaza (Pastaza-Marañon dr.), Ecuador. 


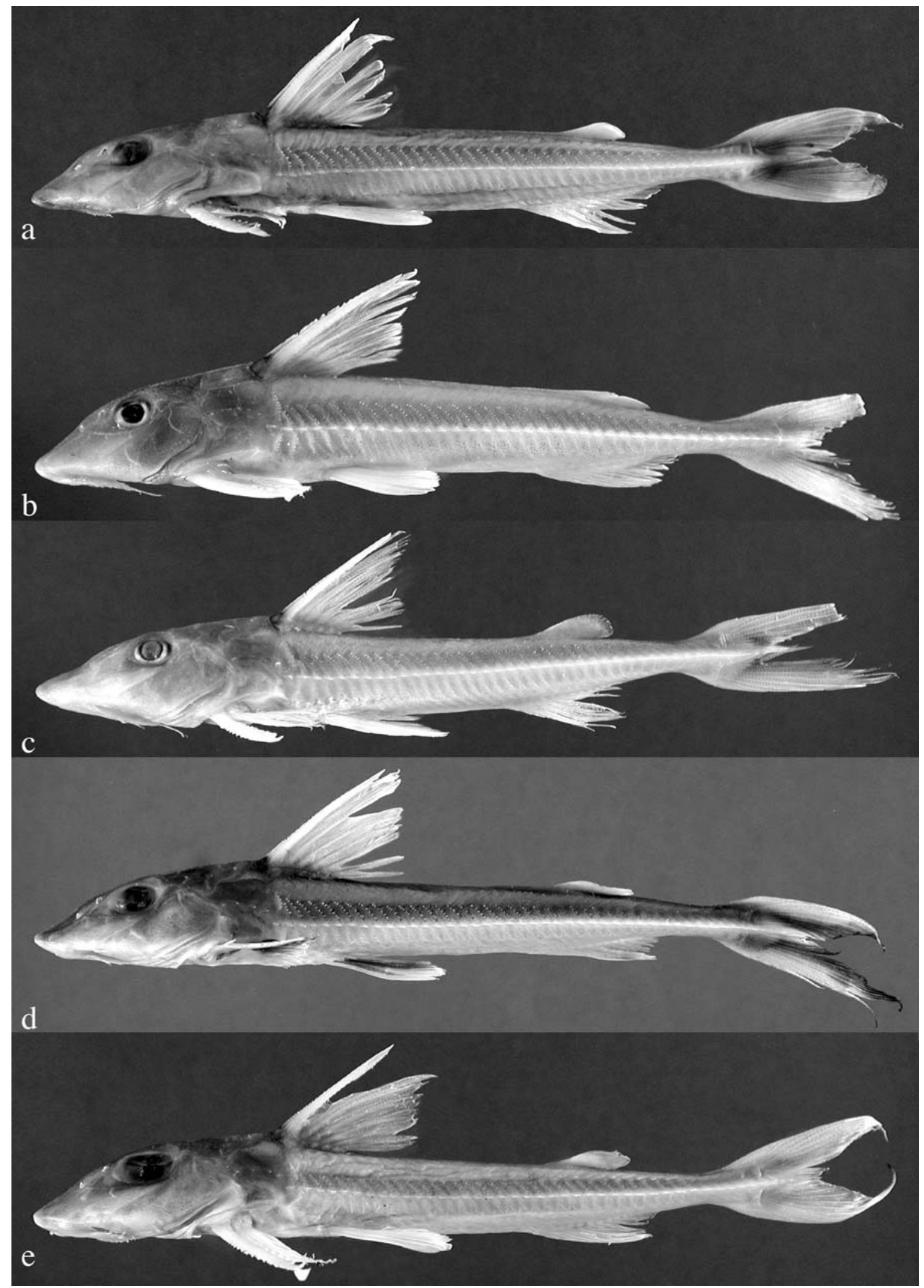

Fig. 18. Juvenile and subadult Leptodoras (Amazon basin). a. L. acipenserinus, FMNH 97140 (SL $113.3 \mathrm{~mm}$ ), río Coca (Napo dr.), Napo, Ecuador. b. L. acipenserinus, ANSP 178467 (SL 107.9 mm), río Nanay, Loreto, Peru. c. L. cf. cataniai Nanay form, INHS 39814 (SL 109.2 mm), río Nanay, Loreto, Peru. d. L. cf. cataniai Amazon form, ANSP 180925 (SL 120.3 mm), rio Iça, Amazonas, Brazil. e. L. cataniai, ANSP 180912 (SL 104.6 mm), rio Negro, Amazonas, Brazil. 
Lower labial extension narrow, attenuate, finishing before upper labial extension. Interlabial membrane narrow (labial extensions convergent), comparatively thin with few small papillae. Dorsolabial membrane weakly developed, evenly attenuate posteriorly. Two pairs of jaw barbels with scattered elongate papillae; cojoined by basal membrane; outer pair slightly longer than inner pair and shorter than maxillary barbel, cojoined with lower labial extension via narrow membrane. Branchiostegal membrane with moderately expanded fleshy margin overlapping ventral gill opening; fleshy inner flap along
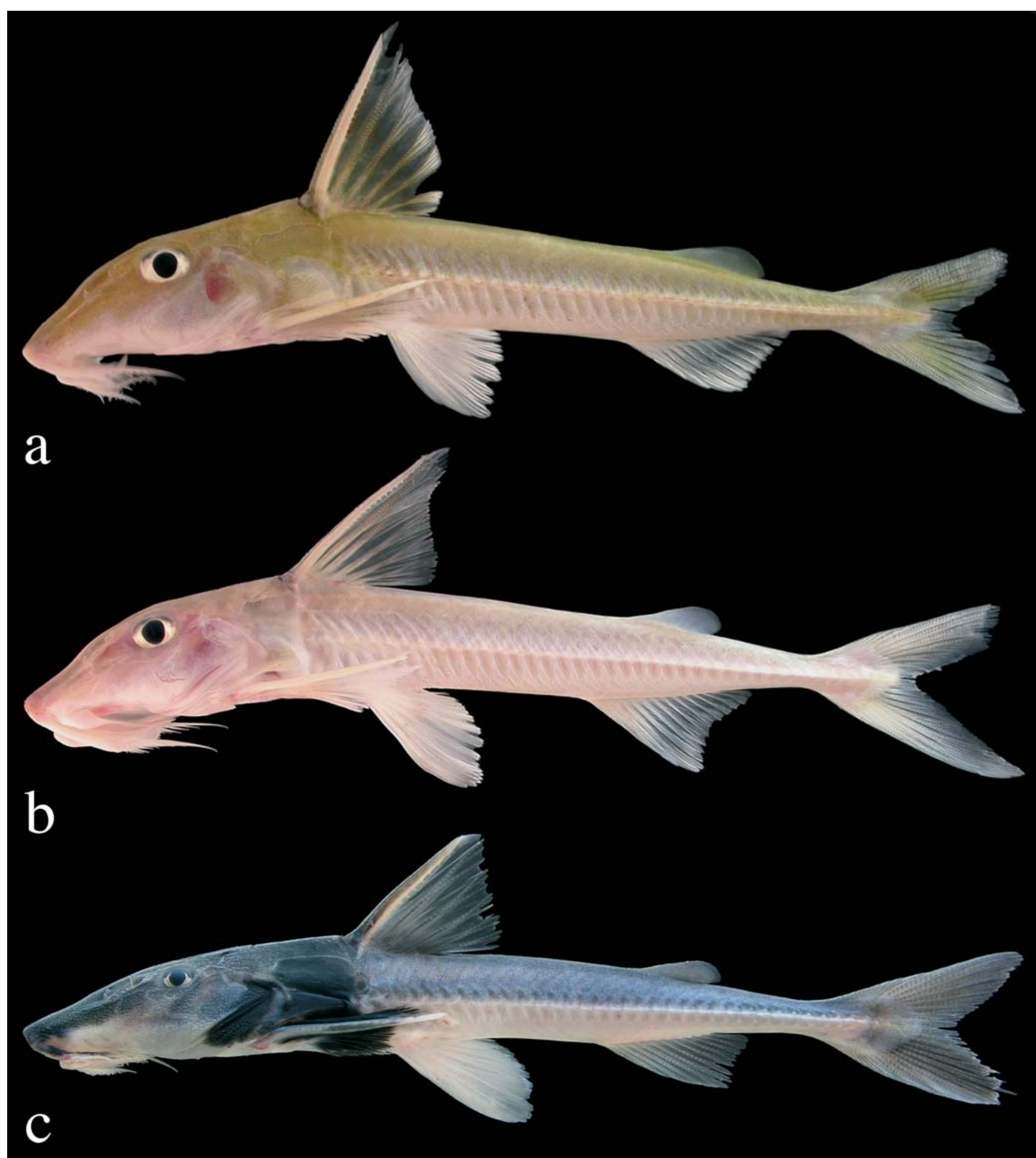

Fig. 19. Live coloration in Leptodoras. a. L. acipenserinus, ANSP 178467 (SL 108 mm), río Nanay (Amazonas dr.), near Iquitos, Loreto, Peru. b. L. cf. cataniai Nanay form, ANSP 179863 (SL 144 mm), ibid. c. L. myersi, ANSP 181045 (SL 78.6 mm), río Amazonas, near Iquitos, Loreto, Peru. 
cleithrum usually complete, nearly reaching cleithral notch. Morphology of first gill arch similar to L. linnelli.

Sum of midlateral plates 77-86 (modally 82 , Table 3 ). Anterior midlateral plates deep, covering at least half of corresponding body depth; posterior margins of dorsal and ventral wings rounded with many small serrae. Tympanum usually with 3 distinct ossifications (simple or dual spines) along postotic laterosensory canal; small fixed spine usually conspicuous along posterior margin of neurocranium where postotic laterosensory canal exits supracleithrum. Postcleithral process rather robust, short and very deep, distal portion dome shaped with straight ventral margin. Middorsal groove on nuchal shield usually well-defined. Subrectangular nuchal foramina present, replacing suture between epioccipital and anterior nuchal plate. Skin often with distinct fleshy papillae on snout and upper head; papillae consolidated to form low pair of ridges on middorsal snout and additional ridges along margins of orbit and middorsal groove on nuchal shield.

Dorsal-fin rays I,6; pectoral-fin rays I,9-11 (modally 10); pelvic-fin rays i,6; total anal-fin rays 14-17 (first 4 or 5 unbranched); caudal-fin rays i, $8 / 9$, i; dorsal procurrent caudalfin rays 14-19, ventral procurrent caudal-fin rays 14-19. Dorsal-fin spine of moderate length, comparatively thin, nearly straight, evenly attenuate with sharp tip; anterior denticulations antrorse, rather small and crowded basally, absent from distal tip; posterior denticulations retrorse to straight, weak, rather inconspicuous. Pectoral-fin spine sturdy, relatively short, anterior margin weakly curved, posterior margin straight, tip blunt; anterior denticulations antrorse, moderately sized nearly to tip; posterior denticulations becoming gradually larger and less retrorse towards tip of spine (last and/or penultimate denticulation nearly perpendicular to long axis of spine); last posterior denticulation terminal, its lateral margin continuous with tip of pectoral spine. Pelvic fin of moderate length with straight to weakly rounded distal margin. Anal fin triangular with elongate base; tip of longest branched ray falls well short of vertical through base of last branched ray when fin extended. Caudal fin deeply forked with elongate and pointed lobes.

Coloration in alcohol. Head and body moderately countershaded, upper sides tan or gray-brown, lower sides and undersurfaces white. Wide dusky middorsal stripe usually evident, flanked by lighter areas along upper sides. Melanophores sometimes weakly concentrated in skin between and above dorsal wings of midlateral plates, forming faint dusky stripe.

Dorsal fin with faint stippling on rays, membranes depigmented, clear; darker stippling along anterior margin of dorsal spine and on skin surrounding dorsal-locking spine and along fin insertion. Pectoral fin with faint stippling on anterior rays and membranes, posterior rays and membranes depigmented, melanophores most concentrated on skin between posterior denticulations of pectoral spine. Pelvic fins with faint stippling on dorsal surfaces. Anal fin cream, hyaline. Elongate preadipose ridge light (depigmented) and of- ten well contrasted with dusky middorsal stripe. Caudal fin with divergent pair of broad diffuse stripes, one on lower half of upper lobe and other on upper half of lower lobe; lower stripe distally expanded along margin of ventral-most rays and membranes.

Coloration in life. Live specimens from the río Nanay, Peru, are light olive in dorsal half of head and body; basal portions of dorsal and caudal fins also with light olive tinge (Fig. 19a).

Distribution and habitat. Leptodoras acipenserinus is known from widely separate sites along the cis-Andean piedmont in the upper Amazon basin in Ecuador, Peru and Brazil (Fig. 16). Most specimens are from upland areas in the upper Napo, Marañon (i.e., Huallaga and Pastaza), Ucayali and upper Madeira (i.e., Guaporé and Madre de Dios) systems. A few specimens have been collected in lowland tributaries of the río Amazonas (i.e., Itaya and Nanay) near Iquitos. Leptodoras acipenserinus has not been found in or near the main channel of the río Amazonas downstream of Iquitos. Most specimens are from whitewaters, however this species inhabits moderately blackwater rivers as well (e.g., río Nanay). In the río Nanay it was collected at night with Leptodoras $c f$. cataniai over a large sandy beach in swift-flowing water.

Type-material examined. Oxydoras acipenserinus: holotype (unique), BMNH 1867.6.13.32 (178.0 mm), Xeberos, upper Amazons, E. Bartlett [Xeberos (= Jeberos) is a village in the Peruvian Amazon (Department Loreto) near the río Aipana, a small tributary that joins the río Huallaga near the latter's confluence with the río Marañon (Amazonas Dr.)].

Non-type material. Brazil: FMNH 58189 (3, 110.5-119.5 mm), rio Guaporé (Mamoré-Madeira dr.), Maciel, 23 and 26 Jul 1909. Ecuador: FMNH 88186 (1, 171.0 mm), FMNH 93040 (1, 171.5 $\mathrm{mm}$ ), río Bobonaza (Pastaza-Marañon dr.), Montalvo, Aug 1958; FMNH 88198 (3, 129.7-157.0 mm), FMNH 92625 (2, 122.0, 136.5 $\mathrm{mm}$ ), río Bobonaza (Pastaza-Marañon dr.), Morete Bobonaza, Feb 1958; FMNH 92385 (2*, 155, 196.5 mm), FMNH 92624 (2, 202.0, $203.0 \mathrm{~mm}$ ), río Bobonaza (Pastaza-Marañon dr.), Morete Bobonaza, Nov 1958. Napo: FMNH $97140\left(1^{*}, 113.3 \mathrm{~mm}\right.$ ) río Coca (Napo dr.), $7 \mathrm{~km}$ upstream from confluence with Napo $\left(0^{\circ} 24^{\prime} 36^{\prime \prime S}\right.$, 7659’0"W), 23 Sep 1981, DJS 81-15; FMNH 97141 (2, 115.0, $116.1 \mathrm{~mm}$ ), río Napo (Amazonas dr.), $10.7 \mathrm{~km}$ upstream from bridge at Coca in main stream $\left(0^{\circ} 32^{\prime} 36^{\prime \prime} \mathrm{S}, 7^{\circ} 2^{\prime} 54^{\prime \prime W}\right), 21 \mathrm{Sep} 1981$, DJS 81-11; FMNH 97142 (1, 134.2 mm), río Napo (Amazonas dr.), Pompeya, north shore and tower end of sandy island in center of river $\left(0^{\circ} 26.5^{\prime}, 7^{\circ} 38.2^{\prime}\right), 7$ Oct 1981, DJS 81-42; FMNH 97143 $\left(2^{*}, 131.5,150.9 \mathrm{~mm}\right)$, río Payamino (Napo dr.), $23.3 \mathrm{~km}$ upstream from confluence with Napo $\left(0^{\circ} 26.9^{\prime}, 7^{\circ} 6.2^{\prime}\right)$, 20 Sep 1981, DJS 81-6; FMNH 97144 (1, 167.0 mm) río Napo, río Coca (Amazonas dr.), cocha off mainstream ( $\left.0^{\circ} 27^{\prime} 12^{\prime \prime} \mathrm{S}, 76^{\circ} 59^{\prime} 24^{\prime \prime} \mathrm{W}\right), 26$ Sep 1981 , DJS 81-24; FMNH 97145 (1*, 161.0 mm), río Aguarico (Napo dr.), near Destacamento militar Cuyabeno and confluence of Cuyabeno and Aguarico $\left(0^{\circ} 15.6^{\prime}, 75^{\circ} 53.9^{\prime}\right), 21$ Oct 1983, DJS 83-47; MCZ $48624\left(1^{*}, 141 \mathrm{~mm}\right)$, río Napo (Amazonas dr.), sand bank opposite Coca, 1 Dec 1971, TRR71:1201B. Peru: Loreto: ANSP 178464 (1 $+1^{*}, 108.1 \mathrm{~mm}$ ), río Itaya (Amazonas dr.), bridge on Iquitos-Nauta highway, approximately 25 miles south-southwest of Iquitos, 8 Aug 2001, Peru 2001-03; ANSP 178467 (13 + 3*, 107.5-107.9 
$\mathrm{mm}$ ), río Nanay (Amazonas dr.), Pampa Chica, village $4.54 \mathrm{~km}$ west of Iquitos, 2 Aug 2001, Peru 2001-02. Madre de Dios: ANSP 180550 (1), río Madre de Dios (Madeira dr.), Isla Rolin, ca. 1 hour by boat downstream from Puerto Maldonado (12 33'50"S, 6903'01"W), 29 Jul 2004, TCEP 04-52; ANSP 180630 (1), río Tahuamanu (Orton-Madre de Dios dr.), vicinity of San Lorenzo (11²7'46"S, 69¹8'23"W), 1 Aug 2004, TCEP 04-54; FMNH 70286 (1*, 169.0 mm), Boca Amigo, 8 Nov 1954; CAS 59426 (2, 64.7, $99.5 \mathrm{~mm}$ ), río Madre de Dios (Madeira dr.), on east end, north side of island opposite Cuzco-Amazonico lodge, 4 Jun 1983. Ucayali: USNM 261478 (3, 76.5-86.6 mm), río Aguaytia (Ucayali dr.), Nuevo Requena, 24 Oct 1973.

\section{Leptodoras nelsoni, new species}

Figs. 4f, 5b, 15d and 20

Holotype. ANSP 180917 ( $\left.1^{*}, 117 \mathrm{~mm}\right)$, Colombia, Meta, río Metica (Meta-Orinoco dr.), ca. $1.5 \mathrm{~km}$ east of Rajote, Plancha 267 (356’N, 73³’W), 19 Mar 1973, W.G. Saul and W.F. SmithVaniz, BSS-14.

Paratypes (35). Colombia: Meta: AMNH 236112 [ex. ANSP 134667] (1, $103.7 \mathrm{~mm}$ ), río Metica (Meta-Orinoco dr.), ca. $3 \mathrm{~km}$ southeast of Hacienda Mozambique ( $\left.3^{\circ} 57^{\prime} \mathrm{N}, 73^{\circ} 2^{\prime} \mathrm{W}\right), 30 \mathrm{Mar}$ 1975, BSF-26; ANSP 131336 (2, 99.2-111 mm), same data as holotype; ANSP $134665(2+1 *, 113.8 \mathrm{~mm})$, Río Metica (MetaOrinoco dr.), ca. $3 \mathrm{~km}$ southeast of Hacienda Mozambique (35ํN, 73²'W), 24 Mar 1975, BSF-9; ANSP 134666 (1, 86.9 $\mathrm{mm}$ ), río Metica (Meta-Orinoco dr.), ca. $3 \mathrm{~km}$ southeast of Hacienda Mozambique ( $\left.3^{\circ} 57^{\prime} \mathrm{N}, 73^{\circ} 2^{\prime} \mathrm{W}\right), 20 \mathrm{Mar} 1975$, BSF1; ANSP $134667\left(1+1^{*}, 92.3 \mathrm{~mm}\right)$, same data as AMNH 236112; AUM 28764 (1, 75.5 mm), río Manacacías (Meta-Orinoco dr.), $7 \mathrm{~km}$ south-southeast of Puerto Gaitán at sandbar on left (west) bank, 9 Oct 1978, JSR 78-35; CAS 222740 [ex. ANSP 134665] (1*, $97.9 \mathrm{~mm})$, same data as ANSP 134665; FMNH 117083 [ex. ANSP 134665] (1, $104.7 \mathrm{~mm})$, same data as ANSP 134665; ICNMHN 13571 [ex. ANSP 134667] (1, 95 mm), same data as AMNH 236112; MNHN 2003-0355 [ex. ANSP 134665] (1), UMMZ 245737 [ex. ANSP 134665] (1+1*, $105.5 \mathrm{~mm})$, USNM 384342 [ex. ANSP 134665] (1*, $116.7 \mathrm{~mm})$, same data as ANSP 134665. Venezuela: Apure: ANSP 179101 (1, 100 mm), río Apure (Orinoco dr.), upriver of San Fernando and downriver of mouth of río Portuguesa, JNB-84-V4; ANSP 182200 [ex. MBUCV-V 14769] (1*, 162 mm), río Apure (Orinoco dr.), isla del medio (extremo oeste), 7 Aug 1984; MBUCV-V 10941 (1, $104 \mathrm{~mm})$, río Apure (Orinoco dr.), frente a isla Apurito, 5 Apr 1978; MBUCV-V 14769 (1+3*, 93.3-135.8 mm), same data as ANSP 182200; MBUCV-V 15215 (1, 101.9 mm), río Apure (Orinoco dr.), in front of Jarina lagoon, 25 Jan 1984; MBUCVV 23693 (4, 105-131 mm), caño Bucaral (Orinoco dr.), hacia la boca con el Arauca, 9 Aug 1984; MBUCV-V 24649 (2, 124, 151 $\mathrm{mm}$ ), río Apure (Orinoco dr.), in front of Jarina lagoon, near San Fernando de Apure, 21 May 1983; MBUCV-V 24659 (3, 105-128 mm), río Apure (Orinoco dr.), frente al Aeuropuerto, 18 Feb 1982; MCNG 13167 (1, 93.0 mm), río Apure (Orinoco dr.), 12 km rio abajo de San Fernando de Apure, 16 May 1985, DCT85-13.
Non-type material (7). Colombia: ANSP 149924 (1, $69.6 \mathrm{~mm})$, río Meta (Orinoco dr.), Llanos District near Bogota, pre-1973; FMNH 73408 (1, $75.0 \mathrm{~mm}$ ), río Guaviare (Orinoco dr.), near Mapiripana $\left(2^{\circ} 45^{\prime} \mathrm{N}, 71^{\circ} \mathrm{W}\right)$, Dec 1957, SW 57-1. Venezuela: Apure: MBUCVV 10856 (2), río Apure (Orinoco dr.), Aeropuerto de San Fernando de Apure, 21 Jan? 1958; MBUCV-V 10879 (1, 58.2 mm), río Apure (Orinoco dr.), Jan? 1951; MCNG 13887 (1+1*, 123.5 mm), río Apure (Orinoco Dr.), $10 \mathrm{~km}$ rio abajo de San Fernando de Apure, 15 May 1985, DCT85-11.

Diagnosis. Distinguished among Leptodoras by the following combination: upper labial extension L-shaped, distal half moderately to strongly curved and distinctly expanded with wide lateral flap bearing small fimbriae, sum of midlateral plates modally 78 , plates deep, covering more than $1 / 2$ of body depth, adipose eye weakly developed, preadipose ridge lacking.

Description. Morphometrics summarized in Table 1. Overall shape nearly identical to that of $L$. acipenserinus; body very elongate and dorsoventrally depressed, ventrally flattened from snout to vent; head depressed, short relative to body with long acute snout; dorsal profile of snout shallowly convex from tip to midway between nares; caudal peduncle long, shallow, depressed. Eye moderately sized, more or less centered between snout tip and origin of dorsal-spine, adipose eyelid weakly developed.

Mouth subterminal, jaws edentulous in adults and juveniles as small as $70 \mathrm{~mm}$ SL; smaller specimens not examined, but expected to have few thin acicular teeth near medial symphysis of dentaries. Maxillary barbel long, usually reaching ventromedial extent of gill opening. Secondary maxillary barbels 8-11 (modally 10), flattened, overlapping proximally, separated distally; proximal secondary maxillary barbels with fimbriate anterior margin and smooth posterior margin; distal ones smooth. Oral hood comparatively short overall, not greatly expanded posteriorly, morphology similar to that of $L$. acipenserinus. Upper labial extension elongate, somewhat Lshaped, proximal half straight and narrow, distal half moderately to strongly curved medially and distinctly expanded with wide lateral flap bearing small fimbriae, surface smooth. Lower labial extension narrow, attenuate, finishing before upper labial extension. Interlabial membrane narrow (labial extensions convergent), comparatively thin with few small papillae. Dorsolabial membrane weakly developed, evenly attenuate posteriorly. Two pairs of jaw barbels with scattered elongate papillae; cojoined by basal membrane; outer pair slightly longer than inner pair and shorter than maxillary barbel, cojoined with lower labial extension via narrow membrane. Branchiostegal membrane with narrow fleshy margin weakly overlapping ventral gill opening; fleshy inner flap along cleithrum nearly complete. Morphology of first gill arch similar to L. linnelli.

Sum of midlateral plates 74-80 (modally 78, Table 3). Anterior midlateral plates moderately deep, covering about half of corresponding body depth; posterior margins of dorsal and ventral wings rounded with many small serrae. Tympanum 
usually with 3 distinct ossifications (simple or dual spines) along postotic laterosensory canal; small fixed spine usually conspicuous along posterior margin of neurocranium where postotic laterosensory canal exits supracleithrum. Postcleithral process short and deep, distal portion dome shaped with straight ventral margin. Subrectangular nuchal foramina present, replacing suture between epioccipital and anterior nuchal plate. Middorsal groove on nuchal shield usually well defined. Skin with many small fleshy papillae on dorsal surface and sides of snout, papillae somewhat enlarged on medial portion.

Dorsal-fin rays I,6; pectoral-fin rays I,9-11 (modally 10); pelvic-fin rays i,6; total anal-fin rays 14-17 (first 4 to 6 unbranched); caudal-fin rays i,8/9,i; dorsal procurrent caudalfin rays $14-18$, ventral procurrent caudal-fin rays $12-16$. Dorsal-fin spine of moderate length and width, nearly straight,

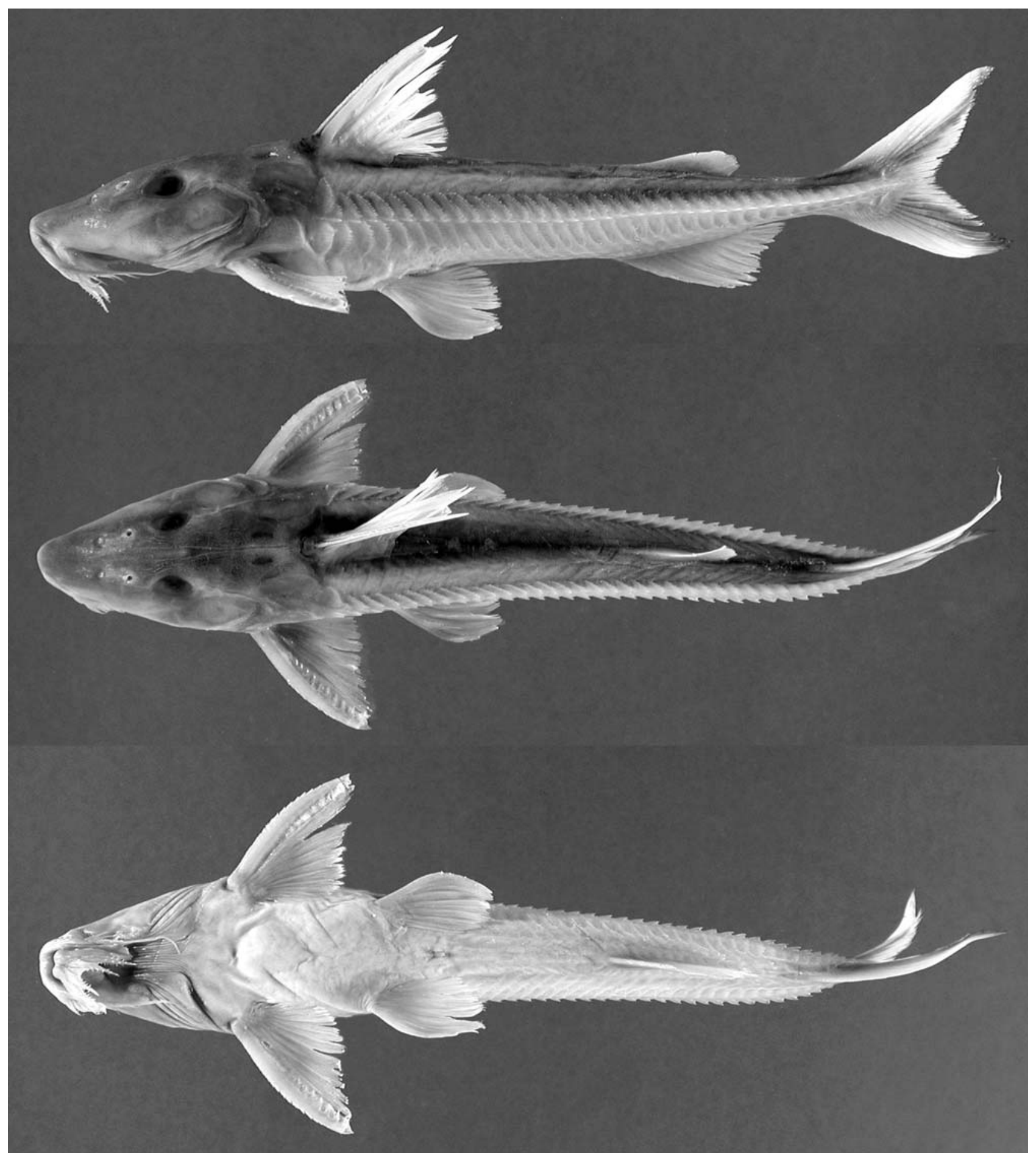

Fig. 20. Leptodoras nelsoni, paratype ANSP 182200 (SL 162 mm), río Apure (Orinoco dr.), Apure, Venezuela. 
evenly attenuate with sharp tip; anterior denticulations antrorse, moderately sized and crowded basally, absent from distal tip; posterior denticulations weakly retrorse to straight, weak, rather inconspicuous. Pelvic fins of moderate length with rounded to weakly pointed distal margin. Pectoral-fin spine, anal fin and caudal fin as described for $L$. acipenserinus.

Coloration in alcohol. Coloration of L. nelsoni is largely as described for L. acipenserinus with two exceptions: divergent pair of dusky stripes on caudal fin very distinct and nuchal foramina often dark gray with dense concentration of melanophores in overlying skin.

Distribution and habitat. Leptodoras nelsoni is presently known from a few east-flowing tributaries of the middle Orinoco: río Guaviare and upper Meta in Colombia and río Apure in Venezuela (Fig. 16). Its distribution likely encompasses other large left-bank tributaries of the Orinoco throughout the cis-Andean piedmont and llanos. Leptodoras nelsoni presumably occupies large river habitats similar to those noted for L. acipenserinus (e.g., whitewaters, swift currents near sandy beaches).

Etymology. Named in honor of Douglas Nelson, for his dedicated service to the ichthyological community since 1983 as Collection Manager of Fishes, University of Michigan Museum of Zoology.

\section{Leptodoras rogersae, new species}

Figs. $5 \mathrm{c}, 15 \mathrm{c}$ and 21

Holotype. USNM 226307 (1*, 180 mm), Venezuela, Bolivar, río Orinoco (Atlantic Dr.), river channel at Palua just below mouth of río Caroni, 181 nautical miles upstream from sea buoy ( $\left.8^{\circ} 21^{\prime} \mathrm{N}, 62^{\circ} 43^{\prime} \mathrm{W}\right), 15$ Feb 1978, J.G. Lundberg, J.N. Baskin et al., JGL 1-78.

Paratypes (13). Venezuela: Amazonas: MCNG 54110 [ex. ANSP 160742] ( $\left.1^{*}, 98.4 \mathrm{~mm}\right)$, río Orinoco (Atlantic dr.), shores of Isla de Ratón ( $\left.5^{\circ} 5^{\prime} \mathrm{N}, 67^{\circ} 48^{\prime} \mathrm{W}\right), 14$ Nov 1985 , V85-18; MNHN 20030356 [ex. ANSP 160742] $\left(1+1^{*}, 90.9 \mathrm{~mm}\right)$, same data as MCNG 54110. Bolivar:AMNH 58175 (1,66.4 mm), río Orinoco (Atlantic

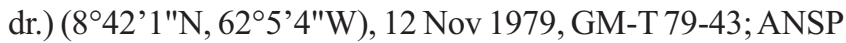
160885 ( $1^{*}, 94.7 \mathrm{~mm}$ ), río Cuchivero (Orinoco dr.), ca. $500 \mathrm{~m}$ from confluence with río Orinoco $\left(7^{\circ} 38^{`} \mathrm{~N}, 65^{\circ} 56^{\prime} \mathrm{W}\right), 18 \mathrm{Nov}$ 1985, V85-28; MBUCV-V 27136 (1, 80.76 mm), río Orinoco (Atlantic dr.), cerca de la boca río Caura, 22 Nov 1985. Delta Amacuro: ANSP 179108 (1,93.9 mm), río Orinoco (Atlantic dr.), between nautical mile buoys 137.4 and 116.5, 12 Nov 1979, T54-79; CAS 58077 (1*, $89.2 \mathrm{~mm}$ ), río Orinoco (Atlantic dr.), bottom drag in deep channel, 11 Nov 1979; FMNH 117084 [ex. MBUCV-V 13372] (1*, $116.7 \mathrm{~mm}$ ), río Orinoco (Atlantic dr.), 137-138.5 nautical miles from sea buoy near Barrancas, $12 \mathrm{Feb}$ 1978; MBUCV-V $13372\left(1^{*}, 128.8 \mathrm{~mm}\right)$, same data as FMNH 117084; LACM 43124 (1, $170 \mathrm{~mm}$ ), deep river channel north of isla Tres Canos, 132 nautical miles upstream from sea, $19 \mathrm{Feb}$ 1978, JNB-36-78; MCZ 68120 (1, 78 mm), río Orinoco (Atlantic dr.), deep channel bottom at river km 137, near Barrancas $\left(8^{\circ} 42^{\prime} \mathrm{N}\right.$, 62 ${ }^{\circ}$ 'S), 12 Nov 1979; USNM 265710 (1*, $\left.107.05 \mathrm{~mm}\right)$, channel of río Orinoco (Atlantic dr.), at buoy 129.7 to buoy 130.4, at isla Tres Canos, downstream from el Consejo and Barrancas (8³9’48"N, 6158’40"W), 14 Nov 1979, T-55-79.

Non-types. Venezuela: ANSP $152863(1,85.3 \mathrm{~mm})$, río Orinoco (Atlantic dr.), Orinoco delta region, Nov 1979. Amazonas: ANSP $160742(44+1 *, 98.6 \mathrm{~mm})$, río Orinoco (Atlantic dr.), shores of Isla de Ratón (55' $\left.\mathrm{N}, 67^{\circ} 48^{\prime} \mathrm{W}\right), 14$ Nov 1985, V85-18; Bolivar: MBUCV-V 15843 (1, $79.6 \mathrm{~mm}$ ), río Orinoco (Atlantic dr.), $50 \mathrm{mts}$. de la boca de Cuchivero, Nov 1985; MBUCV-V 15939 (6), río Orinoco (Atlantic dr.) playas, canales, lagunas y islas cerca puerto las Majadas, confluencial de Orinoco con el Caura, 23 Nov 1985. Delta Amacuro: ANSP 179105 (1), río Orinoco (Atlantic dr.), sandy beach on Isla Paloma, 101 nautical miles from sea buoy $\left(8^{\circ} 32^{\prime} 36^{\prime \prime} \mathrm{N}\right.$, 61³2'12"W), 22 Nov 1979, ECM-27-79; MBUCV-V 13724 (1, $72.8 \mathrm{~mm}$ ), río Orinoco (Atlantic dr.), cerca de la boca del Caño Arutaye, 20 Nov 1979.

Diagnosis. Distinguished among Leptodoras by the following combination: sum of midlateral plates modally 83 or 84 , plates moderately deep, covering $1 / 4$ to $1 / 2$ of body depth, adipose eye moderately developed, preadipose ridge weakly developed, distal medial margin of upper labial extension not forming enlarged or elongated triangular tip.

Description. Morphometrics summarized in Table 1. Overall shape similar to L. acipenserinus and L. nelsoni except body slightly more robust and snout comparatively shorter, distance from tip to posterior nares 33.8-35.9\% of predorsal distance (vs. 36.1-40.3\% and 36.4-40\% in L. acipenserinus and $L$. nelsoni, respectively). Eye moderately sized, center distinctly anterior of midpoint between snout tip and origin of dorsal spine; adipose eyelid moderately developed.

Mouth subterminal, jaws edentulous in adults, juveniles under $75 \mathrm{~mm}$ SL with few thin acicular teeth near distal medial symphysis of dentaries. Maxillary barbel long, usually reaching ventromedial extent of gill opening. Secondary maxillary barbels 9-13 (modally 11), flattened, overlapping proximally, separated distally; proximal secondary maxillary barbels with fimbriate anterior margin and smooth posterior margin; distal ones smooth. Oral hood as in L. acipenserinus and L. nelsoni except comparatively longer, distance from jaw margin to tip of upper labial extension 29.2-35.5\% of predorsal distance (vs. 20.9-29\% and 19.1-28\% in L. acipenserinus and L. nelsoni, respectively); dorsolabial membrane moderately developed. Branchiostegal membrane with moderately expanded fleshy margin overlapping ventral gill opening; fleshy inner flap along cleithrum usually complete, nearly reaching cleithral notch. Morphology of first gill arch similar to L. linnelli.

Sum of midlateral plates $82-86$ (modally 83 and 84 , Table 3). Anterior midlateral plates of moderate depth, covering less than half of corresponding body depth; posterior margins of dorsal and ventral wings rounded with many small serrae. Tympanum without conspicuous ossifications or with 2 or 3 very small spines along postotic laterosensory canal; small fixed spine usually present (but inconspicuous) where 
postotic laterosensory canal exits supracleithrum. Postcleithral process short, moderately expanded posteriorly. Middorsal groove on nuchal shield usually well-defined. Subrectangular nuchal foramina present, replacing suture between epioccipital and anterior nuchal plate. Skin with very small fleshy papillae on snout; papillae scattered, not forming conspicuous ridges.
Dorsal-fin rays I,6; pectoral-fin rays I,10; pelvic-fin rays i,6; total anal-fin rays 15-17 (first 4 or 5 unbranched); caudalfin rays i, $8 / 9$, i; dorsal procurrent caudal-fin rays $15-16$, ventral procurrent caudal-fin rays about 14 . Dorsal-fin spine of moderate length, nearly straight, rather thin and evenly attenuate with sharp tip; anterior denticulations antrorse, mod-
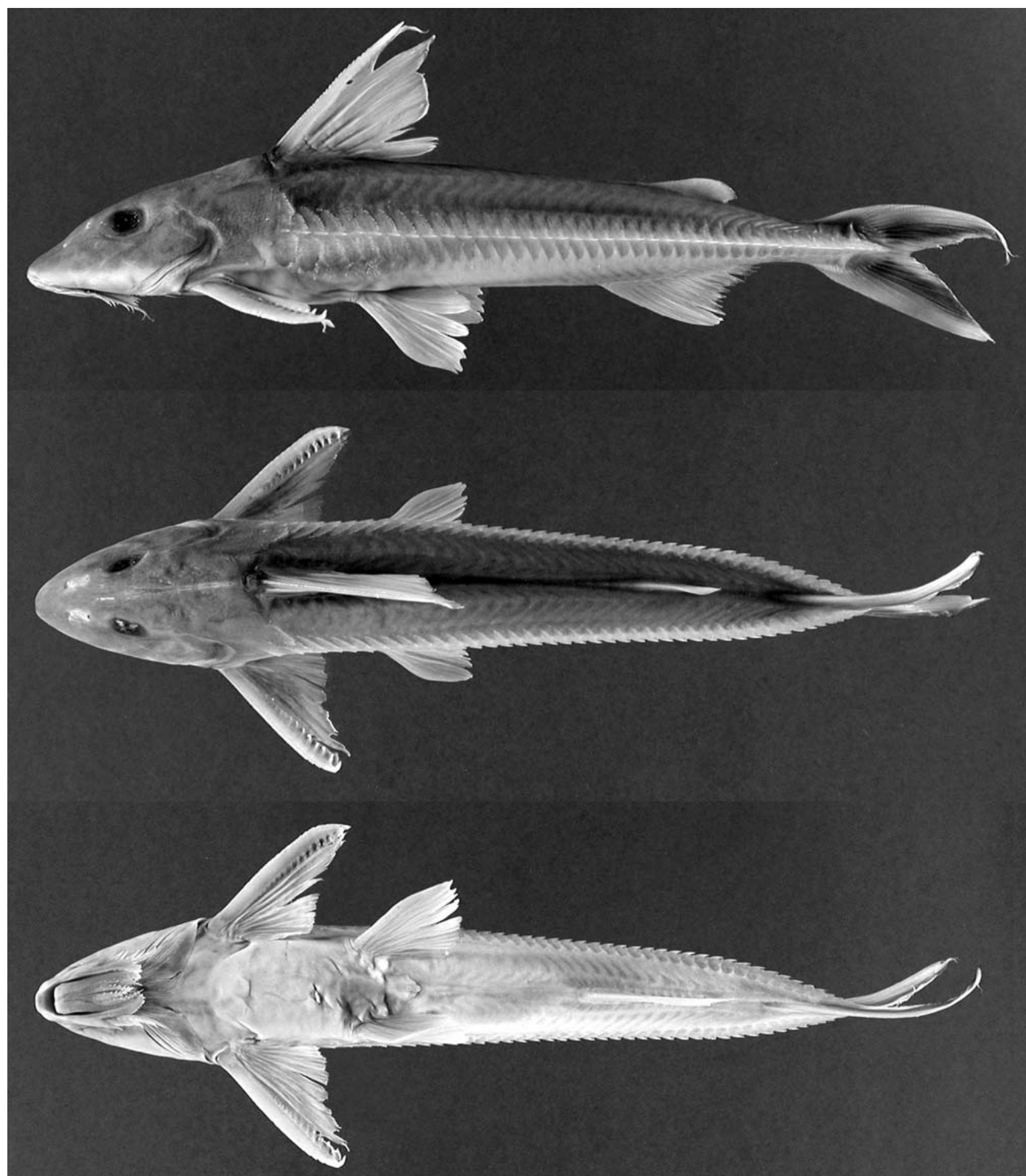

Fig. 21. Leptodoras rogersae, holotype USNM 226307 (SL $180 \mathrm{~mm}$ ), río Orinoco (Atlantic dr.), Palua just below mouth of río Caroni, Bolivar, Venezuela. 
erately sized, absent from distal tip; posterior denticulations small, retrorse basally, becoming straight towards tip. Pectoral-fin spine as described for L. acipenserinus. Pelvic fin weakly pointed and slightly longer (average length $17.1 \%$ of $\mathrm{SL})$ than in L. acipenserinus (15\%) and L. nelsoni (15.4\%). Anal fin triangular with elongate base; tip of longest branched ray falls well short of vertical through base of last branched ray when fin extended. Adipose fin usually with weak preadipose ridge (not as well developed as in L. acipenserinus and L. linnelli). Caudal fin deeply forked with elongate and pointed lobes.

Coloration in alcohol. Pattern on body and fins similar to that of $L$. acipenserinus and $L$. nelsoni, but more faintly expressed overall. Weakly countershaded, upper sides tan or gray, lower sides and undersurfaces white. Broad dusky middorsal and midlateral stripes faint. Divergent dusky stripes on caudal fin distinct as in L. nelsoni.

Distribution and habitat. Leptodoras rogersae is known from the río Orinoco from Isla Ratón (near mouth of río Vichada, northwestern Amazonas) to the delta, Venezuela (Fig. 16). Nearly all collections are from the main channel of the río Orinoco. One is from the río Cuchivero near its confluence with the Orinoco. Many specimens were collected via bottom trawls as deep as $14 \mathrm{~m}$. This species is probably restricted to the main channel of the lower to middle Orinoco and the mouths of its largest tributaries.

Etymology. Named in honor of Mary Anne Rogers, for her dedicated service to the ichthyological community since 1988 as Collection Manager of Fishes, Field Museum of Natural History.

\section{Leptodoras cataniai, new species}

Figs. 4g, 5g, 6b, 18e and 22

Holotype. ANSP 180918 (1*, $171 \mathrm{~mm})$, Venezuela, Amazonas, río Casiquiare from mouth of río Pamoni to $4 \mathrm{~km}$ below mouth, west of Pamoni ( $\left.2^{\circ} 48^{\prime} \mathrm{N}, 65^{\circ} 57^{\prime} \mathrm{W}\right), 17$ Mar 1987, B. Chernoff, O. Castillo and C. Garrido, V87-27.

Paratypes (28). Brazil: Amazonas: ANSP 131431 (1*, 110.6 $\mathrm{mm}$ ), west of Moura, near junction of rio Negro and rio Branco (1³0'S, 614ㅇ'W), Apr 1967; MCZ 101046 (8), rio Negro (Amazonas dr.), Ilha de Jacaré, 1991. Venezuela: Amazonas: AMNH 236111 (1, $151 \mathrm{~mm})$, ANSP $161532\left(5+1^{*}, 146.5 \mathrm{~mm}\right)$, same data as holotype; ANSP 161533 (2, 145.5-173.3 mm), río Casiquiare, main channel ca. $1.5 \mathrm{hrs}$ from its confluence with río Orinoco $\left(3^{\circ} 5^{\prime} \mathrm{N}, 65^{\circ} 55^{\prime} \mathrm{W}\right), 16 \mathrm{Mar} 1987$, H. Lopez and O. Castillo, V87-24; CAS 222741 (1*, 153.7 mm), FMNH 117085 [ex.ANSP 161532] $\left(1^{*}, 149.5 \mathrm{~mm}\right)$, INPA 25071 $\left(1^{*}, 138.2 \mathrm{~mm}\right)$, same data as holotype; MBUCV-V $25604\left(2^{*}, 158.8,160 \mathrm{~mm}\right)$, río Casiquiare, ca. $1.5 \mathrm{hrs}$ des de boca en río Orinoco, $16 \mathrm{Mar}$ 1987; MCNG 54111 [ex. ANSP 161533] (1, $162.5 \mathrm{~mm})$; MCP 38652 [ex. ANSP 161533], $\left(1^{*}, 142.8 \mathrm{~mm}\right)$, same data as ANSP 161533; MZUSP 88065 (1*, $139.6 \mathrm{~mm})$, same data as holotype;
UNT 3782 [ex. ANSP 161533] $\left(1^{*}, 138.5 \mathrm{~mm}\right)$, same data as ANSP 161533; USNM $384343\left(1^{*}, 149.6 \mathrm{~mm}\right)$, same data as holotype.

Non-types. Brazil: Amazonas: ANSP 178535 (1), rio Negro (Amazonas dr.), 7 miles upstream from Leprosario, 7 miles downstream from Santa Maria (3²'12"S, 60²2’40"W), 18 Jul 1996, MTP-96-008; ANSP 180919 (1), rio Negro (Amazonas dr.), 10 km downstream from Carvoeiro (1 $\left.{ }^{\circ} 22^{\prime} 8^{\prime \prime S}, 61^{\circ} 54^{\prime} 22^{\prime \prime W}\right), 9$ Dec 1993 , JGL-93-190; ANSP 180920 (2*, 97.7, 104.6 mm), rio Negro (Amazonas dr.), $3.8 \mathrm{~km}$ downstream from S. Francisco ( $1^{\circ} 41^{\prime} 10^{\prime \prime} \mathrm{S}$, 612'ㄱ"W), 6 Dec 1993, JPF-93-158; ANSP 180921 (2 + 1*, $116.8 \mathrm{~mm}$ ), rio Negro (Amazonas dr.), $37.8 \mathrm{~km}$ upstream from

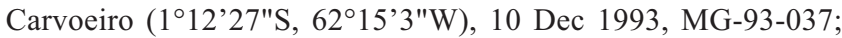
ANSP 180922 (1), rio Negro (Amazonas dr.), 15.7 km downstream from Moura, below rio Branco (1³3'51"S, 6133'W), 7 Dec 1993, JNB-93-012. Leptodoras cf. catania (Amazon form): Brazil: Amazonas: ANSP $178544\left(1^{*}, 97.4 \mathrm{~mm}\right)$, rio Madeira (Amazonas dr.), $9 \mathrm{~km}$ upstream from Vila Urucarituba ( $\left.3^{\circ} 35^{\prime} 28^{\prime \prime S}, 58^{\circ} 56^{\prime} 53^{\prime \prime} \mathrm{W}\right)$, 6 Aug 1996, CCF-96-078; ANSP 180923 (1), rio Amazonas (Atlantic dr.), 4 miles downstream from Nova Oriente, upstream from mouth of Madeira (316’29"S, 58 $\left.{ }^{\circ} 56^{\prime} 33^{\prime \prime W}\right), 5$ Aug 1996, CCF96-072; ANSP 180924 (1), rio Amazonas (Atlantic dr.), upstream from Itacoatiara (316’36"S, 5857’1"W), 5 Aug 1996, AMZ-96134; ANSP 180925 ( $\left.7+5^{*}, 120.3-194 \mathrm{~mm}\right)$, rio Içá (Amazonas

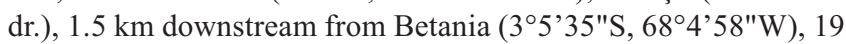
Nov 1993, OTO-93-075; ANSP 180926 (1*, 86.5 mm), rio Jutaí (Solimões dr.), between Pto. Antunes and Foz do Jutaí (2॰50’6"S, 6655'39"W), 13 Nov 1993, JPS-93-049; ANSP 180927 (2, 40.23, $59.6 \mathrm{~mm}$ ), rio Purus (Solimões dr.), $8 \mathrm{~km}$ downstream from Beruri (350’35"S, 61²3’45"W), 26 Jul 1996, FL-96-002; ANSP 180928 $(1,55.1 \mathrm{~mm})$, rio Purus (Solimões dr.), near confluence with Solimões (341'22"S, 6128'19"W), 30 Jul 1996, AMZ-96-110. Para: ANSP 180929 (2), rio Amazonas (Atlantic dr.), $10.2 \mathrm{~km}$ upstream from Monte Alegre, below Tapajos (24’45"S, 5359’49"W), 5 Nov 1994, AMZ-94-023. Roraima: ANSP 178532 (1*, $131.9 \mathrm{~mm})$, rio Branco (Negro dr.), between Atauba and Caruna, $9.3 \mathrm{~km}$ above confluence with Negro (1¹9’34"S, 6152’13"W), 8 Dec 1993, JGL-93-171. Tocantins: UNT 150 (2), rio Tocantins, Pedro Afonso, near confluence with rio Sono ( $\left.8^{\circ} 59^{\prime} \mathrm{S}, 48^{\circ} 10^{\prime} \mathrm{W}\right), 18 \mathrm{Feb} 1996$. Ecuador: Napo: FMNH 97138 (1*, $87.9 \mathrm{~mm})$, río Tiputini, (NapoAmazonas dr.), at confluence with río Napo (048'54"S, 75³2’30"W), 28 Oct 1981, DJS81-64. Peru: Loreto: ANSP 178248 (1*, $77.4 \mathrm{~mm}$ ), río Amazonas (Atlantic dr.), main channel along west bank, ca. 30-45 min. upstream from inlet to Iquitos, mouth of río Itaya, south of Iquitos, 3 Aug 2001, Peru 2001-05. Leptodoras cf. catania (Nanay form): Peru: Loreto: ANSP $73173(1+1 *, 130.5$ $\mathrm{mm}$ ), río Ucayali (Amazonas dr.), Contamana, Jul-Aug 1937; ANSP $178438(3+2 *, 141.8,164.2 \mathrm{~mm})$, río Nanay (Amazonas dr.), Pampa Chica, village $4.54 \mathrm{~km}$ west of Iquitos (large beach along north bank), 2 Aug 2001, Peru 2001-02; ANSP 179863 (5), río Nanay (Amazonas dr.), large beach (left bank) at village of Pampa Chica, $4.54 \mathrm{~km}$ west of Iquitos ( $\left.3^{\circ} 45^{\prime} 9^{\prime \prime} \mathrm{S}, 7^{\circ} 17^{\prime \prime W}\right), 18$ Aug 2003, PERU 2003-05; INHS 39814 (48+5*, 93.1-117.3 mm), río Nanay (Amazonas dr.), playa about $1 \mathrm{hr}$ by canoe upstream from Santa Clara (346.63'S, $\left.73^{\circ} 22.21^{\prime} \mathrm{W}\right), 19$ Aug 1996; INHS 44194 (3), río Nanay (Amazonas dr.), upstream from Santa Clara, $13.9 \mathrm{~km}$ west of Iquitos, bearing $78^{\circ}$ (346' 54.6"S, 73²1'49.6"W), 29-30 Jul 1997, Peru 97-8; INHS $53722(11+2 *, 89.7,94.7 \mathrm{~mm})$, río Nanay (Amazonas dr.), Pampa Chica, $4.54 \mathrm{~km}$ west of Iquitos, bearing $269^{\circ}$ (345'08.8"S, 73¹7’00.1"W), 7 Aug 1999, Peru 99-12; SIUC 28582 (4), same data as INHS 39814; SIUC 29472 (3), río Nanay (Amazonas dr.), playa, just upstream from Santa Clara, $13.9 \mathrm{~km}$ 
(bearing $78^{\circ}$ ) from Iquitos, 29-30 Jul 1997; SIUC 29859 (5 + 4*, 122-181 mm), río Nanay (Amazonas dr.), Pampa Chica, $4.54 \mathrm{~km}$ west of Iquitos, bearing 269, 11 Aug 1997.

Diagnosis. Distinguished among Leptodoras by a specific feature of upper labial extension (Figs. 4g, 5g-i): distal portion distinctly elongated, forming acute tip (sometimes appears as an enlarged terminal fimbriae). In species with similarly shaped upper labial extensions (e.g., L. acipenserinus, nelsoni, rogersae) the distal margin is rounded or with comparatively small terminal fimbriae.

Description. Morphometrics summarized in Table 2. Overall shape similar in L. cataniai sensu stricto and two forms $L$. cf. cataniai Amazon (Figs. 18d, 23) and Nanay (Figs. 18c, 19b, 24 ), close to L. rogersae; body very elongate and dorsoventrally depressed, ventrally flattened from snout to vent; head depressed with acute snout; caudal peduncle long, shallow,

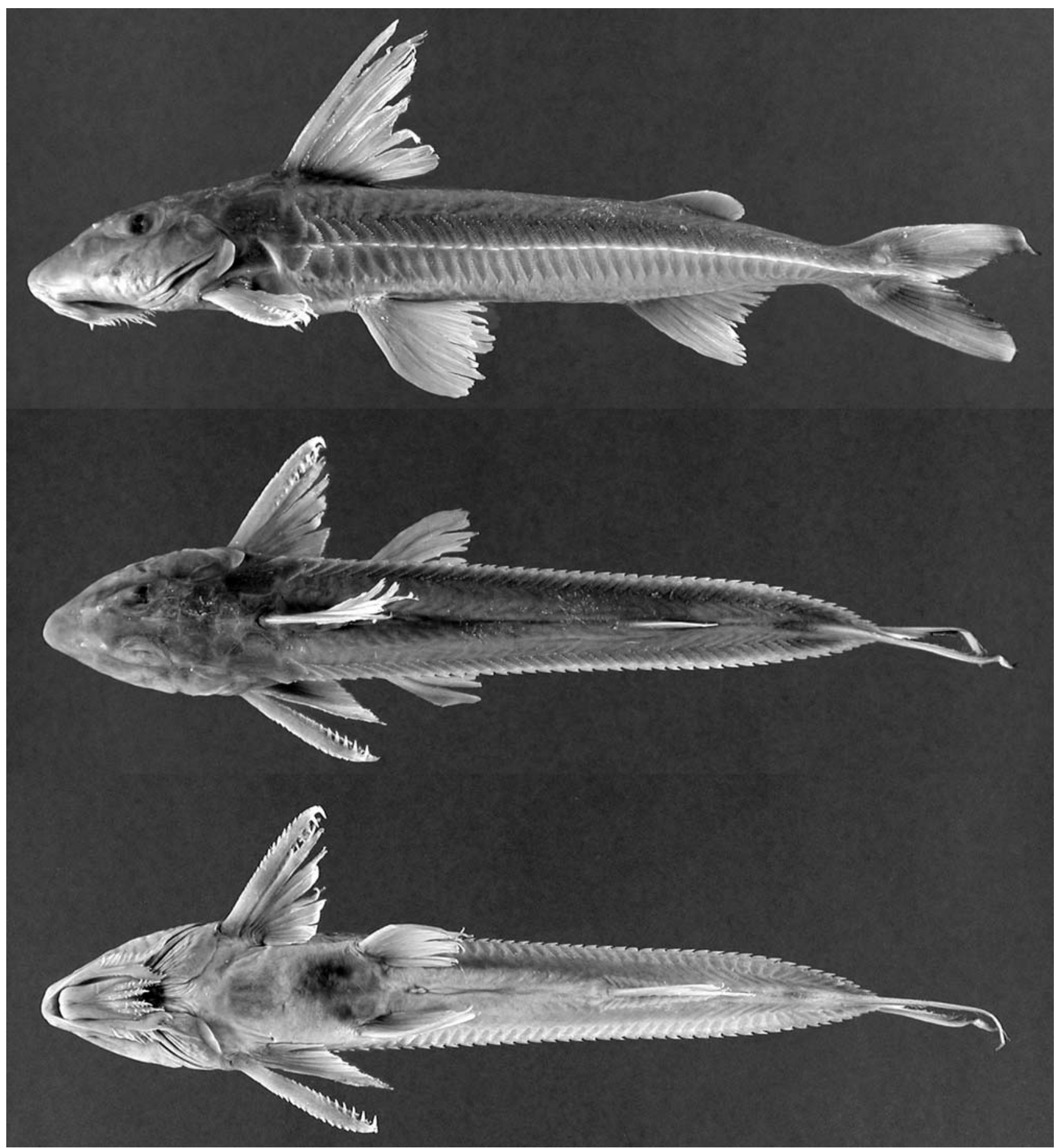

Fig. 22. Leptodoras cataniai, holotype, ANSP 180918 (SL $171 \mathrm{~mm}$ ), río Casiquiare (Negro dr.) from mouth of rio Pamoni to $4 \mathrm{~km}$ below mouth, Amazonas, Venezuela. 
depressed. Relative snout length longest in Nanay form (42.4$46.6 \%$ of predorsal distance), shortest in L. cataniai sensu stricto (35.4-40.2\%), intermediate in Amazon form (37.6-41.3\%). Eye rather large with adipose eyelid moderately (Nanay form) to well-developed (L. cataniai sensu stricto and Amazon form).

Mouth subterminal, jaws edentulous in adults, small juveniles less than $80 \mathrm{~mm}$ SL with few thin acicular teeth near distal medial symphysis of dentaries. Maxillary barbel long, usually reaching ventromedial extent of gill opening. Secondary maxillary barbels 9-12 (modally 10), flattened, overlapping proximally, separated distally; proximal secondary maxillary barbels with fimbriate anterior margin and smooth posterior margin; distal ones smooth. Oral hood very well developed, expanded posteriorly (distance from jaw margin to tip of upper labial extension $33-47.8 \%$ of predorsal distance). Upper labial extension very elongate, proximal half straight and narrow, distal half curved medially and distinctly expanded with wide lateral flap bearing fimbriae, distal tip distinctly acute, often appearing as enlarged terminal fimbriae; surfaces smooth. Lower labial extension narrow, finishing before upper labial extension, tip often slightly expanded with terminal fimbriae. Interlabial membrane narrow (labial extensions convergent), comparatively thin with few small papillae. Dorsolabial membrane very well developed, laterally expanded and widely rounded posteriorly. Two pairs of jaw barbels with scattered elongate papillae; cojoined by basal

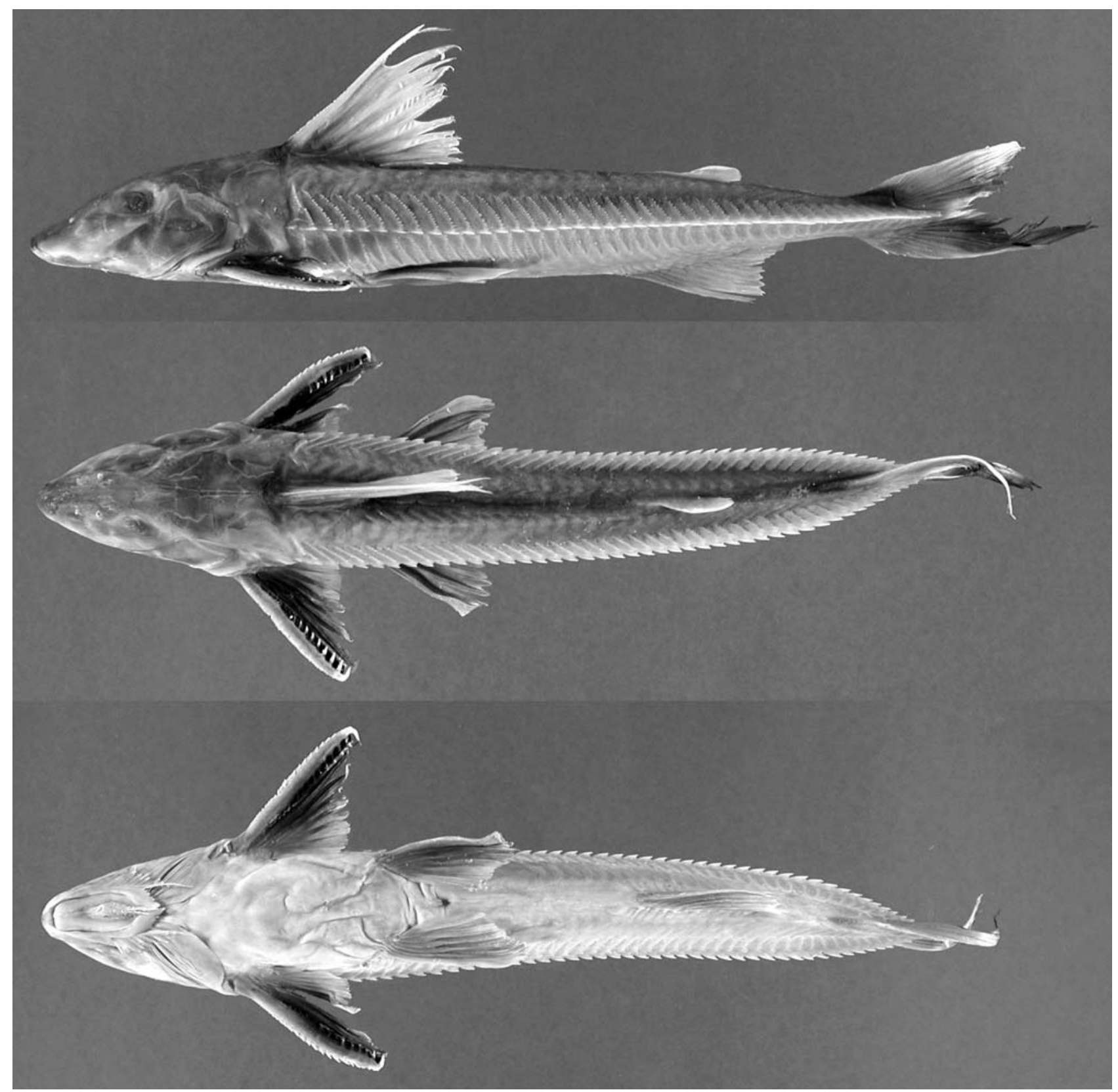

Fig. 23. Leptodoras cf. cataniai Amazon form, ANSP 180925 (SL 194 mm), rio Iça (Amazonas dr.), 1.5 km downstream from Betania, Amazonas, Brazil. 
membrane; outer pair longer than inner pair and shorter than maxillary barbel, cojoined with lower labial extension via narrow membrane. Branchiostegal membrane with well-expanded fleshy margin greatly overlapping ventral gill opening; fleshy inner flap along cleithrum complete, reaching cleithral notch. First gill arch (Fig. 6b) with gill rakers absent or inconspicu- ous, entirely contained within basal membrane (tips not apparent); accessory lamellae well developed, extending from basal membrane across lateral and medial faces of arches and filaments; lamellae numerous, on every second gill filament and broken into column of lappets with first lappet on medial face enlarged, deflected dorsomedially.

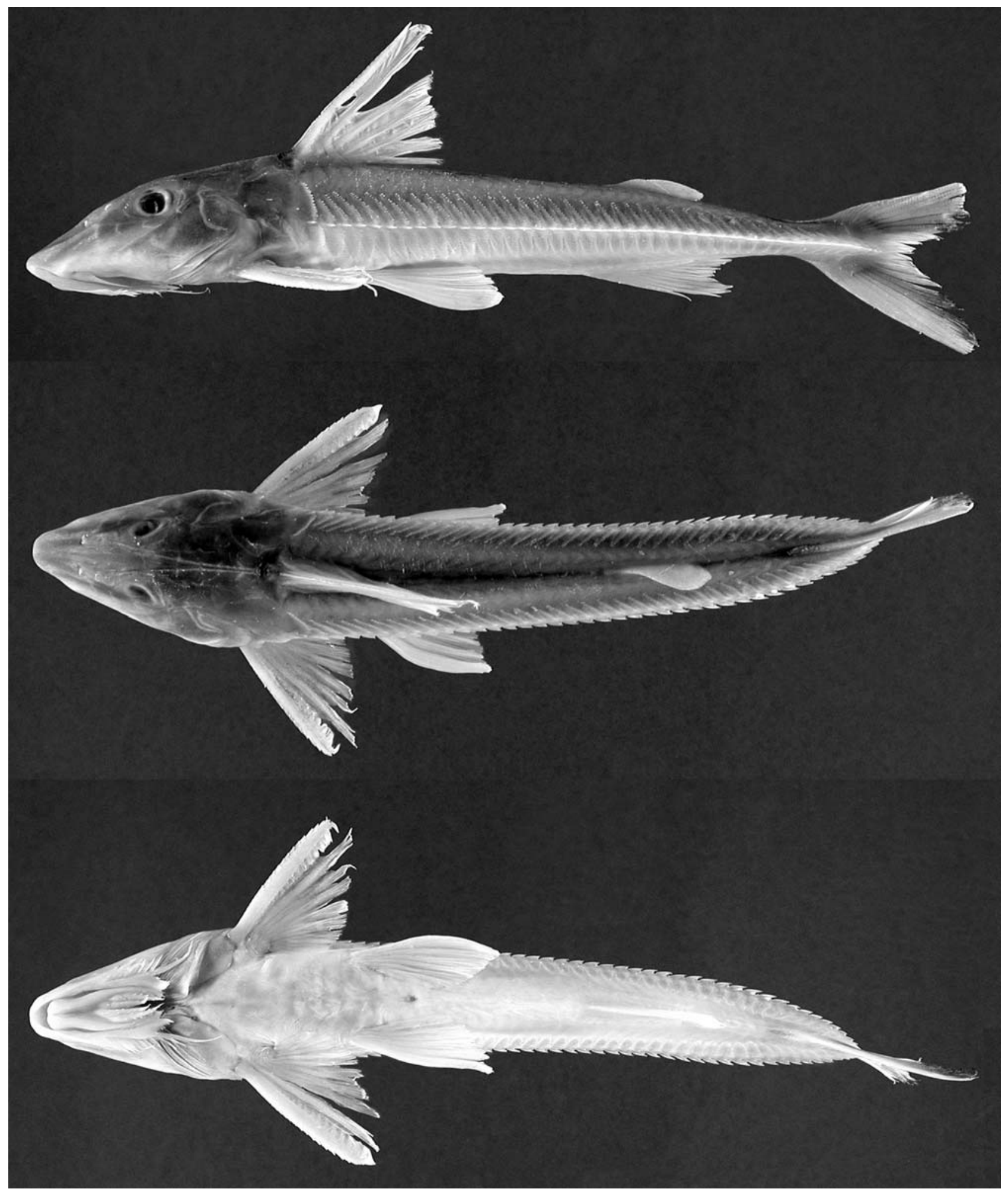

Fig. 24. Leptodoras cf. cataniai Nanay form, ANSP 178438 (SL 164.2 mm), río Nanay (Amazonas dr.), near Iquitos, Loreto, Peru. 
Sum of midlateral plates highly variable (Table 3); lowest in Nanay form (79-86, modally 82), highest in Amazon form (83-92, modally 88), intermediate in L. cataniai sensu stricto (82-87, modally 84). Anterior midlateral plates deep, usually covering at least half of corresponding body depth; posterior margins of dorsal and ventral wings rounded with many small serrae. Tympanum usually with 3 distinct ossifications (simple spines) along postotic laterosensory canal; small fixed spine usually conspicuous along posterior margin of neurocranium where postotic laterosensory canal exits supracleithrum. Postcleithral process very short and deep, distal portion expanded (especially dorsally) and dorsal and distals margin usually indistinct, covered with skin. Middorsal groove on nuchal shield well-defined. Subrectangular nuchal foramina present, replacing suture between epioccipital and anterior nuchal plate. Skin relatively smooth.

Dorsal-fin rays I,6; pectoral-fin rays I,9-11 (modally 10); pelvic-fin rays i,6; total anal-fin rays 14-17 (first 4 or 5 unbranched); caudal-fin rays i,8/9,i; dorsal procurrent caudalfin rays $14-19$, ventral procurrent caudal-fin rays 12-16. Dorsal-fin spine rather long, very thin, relatively straight in juveniles, becoming sinuous in large adults; anterior denticulations antrorse, rather small and crowded basally, absent from distal third; posterior denticulations weakly retrorse to straight, weak, rather inconspicuous. Pectoral-fin spine as in L. acipenserinus. Pelvic fin comparatively long and pointed. Anal fin triangular with falcate distal margin; tip of longest branched ray more or less even with vertical through base of last branched ray when fin extended. Caudal fin deeply forked with elongate and pointed lobes.

Coloration in alcohol. Overall pattern similar to that of $L$. acipenserinus, nelsoni and rogersae. Head and body weakly to moderately countershaded, upper sides tan or gray-brown, lower sides and undersurfaces white. Wide dusky middorsal stripe evident in Amazon and Nanay forms, rather faint in $L$. cataniai sensu stricto. Melanophores weakly concentrated in skin between and above dorsal wings of midlateral plates, forming faint dusky stripe.

Fin coloration exhibits variation presumably influenced by environmental conditions, specifically black $v s$. whitewater habitats. In most specimens from the río Amazonas (whitewater) the fins are rather darkly pigmented. Dorsal fin with faint stippling on rays and along insertion; darker stippling along anterior margin of dorsal spine and on skin surrounding dorsal-locking spine. Pectoral fin dark with melanophores most concentrated on anterior rays, membranes, and skin between posterior denticulations of pectoral spine; posterior membranes with fainter stippling, posterior rays usually depigmented. Pelvic fin with dark stippling on anterior membranes forming streaks distally; rays and posterior membranes depigmented. Anal fin cream, hyaline. Divergent pair of dusky stripes on caudal fin very distinct as in L. nelsoni and $L$. rogersae. In specimens from the rio Negro (L. cataniai sensu stricto) and río Nanay (both blackwaters) the dorsal, pectoral and pelvic fins are almost completely depigmented, cream, hyaline. The dusky divergent stripes on the caudal fin are retained but faint.

Coloration in life. Leptodoras cf. cataniai from the río Nanay, Peru, appear white with a pinkish tint (Fig. 19b).

Distribution and habitat. Leptodoras cataniai sensu stricto is known from the rio Negro/Casiquiare Canal in Brazil and Venezuela (Fig. 25). Leptodoras cf. cataniai is known from in or near the main channel of the río Amazonas (Amazonas form) and large tributaries of the upper Amazonas such as the Nanay and Ucayali (Nanay form). In addition Santos et al. (1984:52) figured (as Leptodoras acipenserinus) a specimen from the lower Tocantins that is referable to $L$. cf. cataniai. In the lower río Nanay L. cf. cataniai is syntopic with $L$. acipenserinus and large schools of juveniles and adults of both species move into shallow, swift waters along large sandy beaches at night. The río Amazonas form has been collected in bottom trawls at depths ranging from 1.7 to $35 \mathrm{~m}$ (J.G. Lundberg, unpubl. data) and occurs syntopically with $L$. juruensis and L. myersi near Iquitos, Peru.

Etymology. Named in honor of David Catania, for his dedicated service to the ichthyological community since 1985 as Collection Manager of Fishes, California Academy of Sciences.

\section{Leptodoras juruensis Boulenger, 1898}

Figs. $4 \mathrm{~h}$ and 26

Leptodoras juruensis Boulenger 1898: 478 (type locality: rio Jurua, Amazonas dr., Brazil).

Diagnosis. Distinguished among Leptodoras by two unique characteristics: body extremely elongate, predorsal distance $26-28 \%$ of SL ( $v s$. predorsal distance $\geq 31 \%$ in all other Leptodoras), and dorsal spine thin, weakly ossified, and prolonged well beyond tip of first ray as long flexible filament.

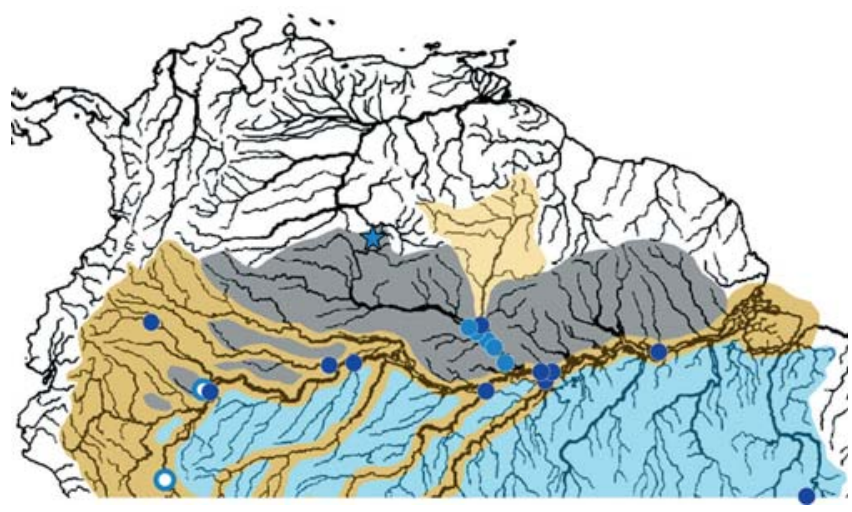

Fig. 25. Distributions of Leptodoras cataniai (solid light blue circles, star denotes type locality), L. cf. cataniai Amazon form (solid dark blue circles) and L. cf. cataniai Nanay form (open circles). 
Description. Overall shape relatively unique among doradids. Head and anterior body dorsoventrally depressed, body extremely elongate, becoming cylindrical posteriorly; predorsal distance relatively short (26-28\% of SL), ventrally flattened from snout to vent, caudal peduncle long and only slightly more shallow than preceding body. Head triangular in dorsal view with acute snout. Eye rather small with weakly developed adipose eyelid.

Mouth subterminal, jaws edentulous in adults; juveniles less than $70 \mathrm{~mm}$ SL usually with few well-formed acicular teeth along distal margin of dentary on either side of medial symphysis. Maxillary barbel comparatively short, usually not reaching ventromedial extent of gill opening. Secondary maxillary barbels 8-11 (modally 9), flattened, overlapping proximally, well separated distally; proximal secondary maxillary barbels with fimbriate anterior margin and smooth posterior margin; distal ones smooth. Oral hood comparatively short overall (i.e., not greatly expanded posteriorly). Upper labial extension thin, curved medially, proximal half straight and narrow, distal half greatly expanded laterally and folded dorsally, appearing confluent with lower labial extension; margin entire (fimbriae absent). Two pairs of jaw barbels with comparatively few scattered elongate papillae; cojoined by basal membrane; outer pair longer than inner pair and shorter than maxillary barbel, cojoined with lower labial extension via narrow membrane. Branchiostegal membrane with narrow fleshy margin weakly overlapping ventral gill opening; fleshy inner flap along cleithrum absent. Morphology of first gill arch similar to L. cataniai.

Sum of midlateral plates 89-91 (modally 90, Table 3). Anterior midlateral plates comparatively shallow, covering about $1 / 4$ of corresponding body depth; posterior margins of dorsal and ventral wings rounded with small serrae. Tympanum usually without distinct ossifications along postotic laterosensory canal; however, small fixed spine usually conspicuous along posterior margin of neurocranium where postotic laterosensory canal exits supracleithrum. Postcleithral process moderately elongate, expanded posteriorly; proximal dorsal margin strongly concave (hemicircular), dorsoposterior margin moderately convex. Middorsal groove on nuchal shield well defined, continuous with middorsal furrow between orbits and anterior groove between nares. Subrectangular nuchal foramina present, replacing suture between epioccipital and anterior nuchal plate. Skin with many small fleshy papillae scattered over snout and dorsal surface of head.

Dorsal-fin rays I,6; pectoral-fin rays I,10; pelvic-fin rays i,6; total anal-fin rays 16-18 (first 5 or 6 unbranched); caudalfin rays i,8/9,i; dorsal procurrent caudal-fin rays $16-18$, ventral procurrent caudal-fin rays 14-17. Dorsal-fin spine weakly ossified, very thin, prolonged well beyond tip of first ray as long flexible filament; anterior denticulations antrorse, very small, inconspicuous; posterior denticulations retrorse, weak and inconspicuous, confined to base. Pectoral-fin spine sturdy, short, anterior margin weakly curved, posterior margin straight, tip blunt; anterior denticulations antrorse, mod- erately sized nearly to tip; posterior denticulations conspicuous, becoming gradually larger and less retrorse towards tip of spine (last and/or penultimate denticulation nearly perpendicular to long axis of spine); last posterior denticulation terminal, its lateral margin continuous with tip of pectoral spine. Pelvic fins comparatively long, bluntly pointed. Anal fin triangular with elongate base; tip of longest branched ray falls well short of vertical through base of last branched ray when fin extended. Caudal fin deeply forked with elongate and pointed lobes.

Coloration in alcohol. Moderately countershaded; dorsal half of snout, head, body (above medial spines of plates) medium to dark gray; undersurfaces and lower sides of head and body (including ventral portion of plates and their median spines) white. Wide dusky middorsal stripe usually evident. Anterior face of cleithrum and dorsoposterior margin of operculum often with dark stippling sometimes forming small irregular blotches. Maxillary barbels usually countershaded, gray above, white below; tip of snout often with narrow dark patch on either side above insertion of maxillary barbel.

Fin coloration somewhat unique among Leptodoras. Adults with variable concentrations of black pigment in dorsal, anal, caudal, and paired fins. Dorsal fin with wide black band along base, dark pigment concentrated on bases of rays and membranes, absent or faint on spine, distal portion of fin depigmented, hyaline. Pectoral fin often intensely black with narrow light distal margin; pigment most concentrated near base of fin, restricted to membranes distally, faint on spine. Pelvic fin with dusky base forming narrow black streaks on membranes, distal margin white. Anal fin sometimes with dusky band on basal half, band widens anteriorly to form dark blotch. Base of caudal fin dusky, interrupted midlaterally by narrow depigmented area. Upper caudal-fin lobe with dusky basal blotch, distal portion white, hyaline. Lower caudal-fin lobe with narrow black steaks formed by concentration of pigment on membranes, dark pigment lacking on rays and along distal margin.

Remarks. The caudal-fin pigmentation in L. juruensis (i.e., lower lobe dusky) is convergent with that of a few North American cypriniform fishes peculiar to deep, swift channels of large rivers. Examples include several minnows in the genera Macrhybopsis and Platygobio (Page \& Burr, 1991) and juveniles of the blue sucker, Cycleptus elongatus (Etnier \& Starnes, 1993).

Distribution. Leptodoras juruensis is known from the main channel of the río Amazonas from Iquitos, Peru downriver to near its mouth at the confluence of the rio Xingu, Brazil, and from the lower courses of large Amazonas tributaries (Içá, Juruá, Japurá, Purus, Madeira) (Fig. 27). This species appears restricted to the deep, rather swift channels of very large whitewater rivers. In the Brazilian Amazon J.G. Lundberg et al. (unpubl. data) collected L. juruensis in bottom trawls at 
depths ranging from 1 to $50 \mathrm{~m}$. Similar trawling efforts by Lundberg et al. in large blackwater tributaries of the Amazon (e.g., rio Negro) did not yield specimens of L. juruensis. In Peru juveniles were collected by dragging a net with canoes over large sand/silt shoals in the main channels of the río Amazonas where this species is syntopic with $L$. cf. cataniai and L. myersi.

Type-material examined. Leptodoras juruensis: holotype (unique), BMNH 1898.10.11.25 (223.0 mm), Brazil, rio Juruá (Amazonas dr.), Jul 1897, J. Bach.

Non-type material. Brazil: Amazonas: ANSP 178682 (1), rio
Solimões (Amazonas dr.), $8.5 \mathrm{~km}$ upstream from S. Antônio do Içá (3¹0’39"S, 6755'40"W), 21 Nov 1993, JGL-93-103; ANSP 180899 $(1,288 \mathrm{~mm})$, rio Solimões (Amazonas dr.), $2.8 \mathrm{~km}$ downstream of Uara, below mouth of rio Juruá $\left(2^{\circ} 38^{\prime} 21^{\prime \prime} \mathrm{S}, 65^{\circ} 33^{\prime} 9^{\prime \prime} \mathrm{W}\right), 5$ Nov 1993, JPF-93-034; ANSP 180930 (1), rio Solimões (Amazonas dr.), $14 \mathrm{~km}$ upstream from Nova Tonantins $\left(2^{\circ} 58^{\prime} 32.7^{\prime \prime} \mathrm{S}, 67^{\circ} 49^{\prime} 48.5^{\prime \prime} \mathrm{W}\right)$, 1993, MG-93-23; FMNH 116135 (1), rio Japurá (Amazonas dr.), between towns Serraria and Porto Caborira (310’34"S, 6446'11"W), 29 Oct 1993, JGL-93-012; FMNH 116136 (3), rio Jurua (Amazonas dr.), between towns Pauapixuna and Vitória, 9 Nov 1993, JGL-93035; FMNH 116137 (1), rio Solimões (Amazonas dr.), between towns Foz do Jutaí and Ponta Grossa (2³1'10"S, 66³6’45"W), 12 Nov 1993, JGL-93-046; FMNH 116138 (1), rio Solimões (Amazonas dr.), between towns Siria and Foz do Jutaí (240’55"S, 6653’20"W),

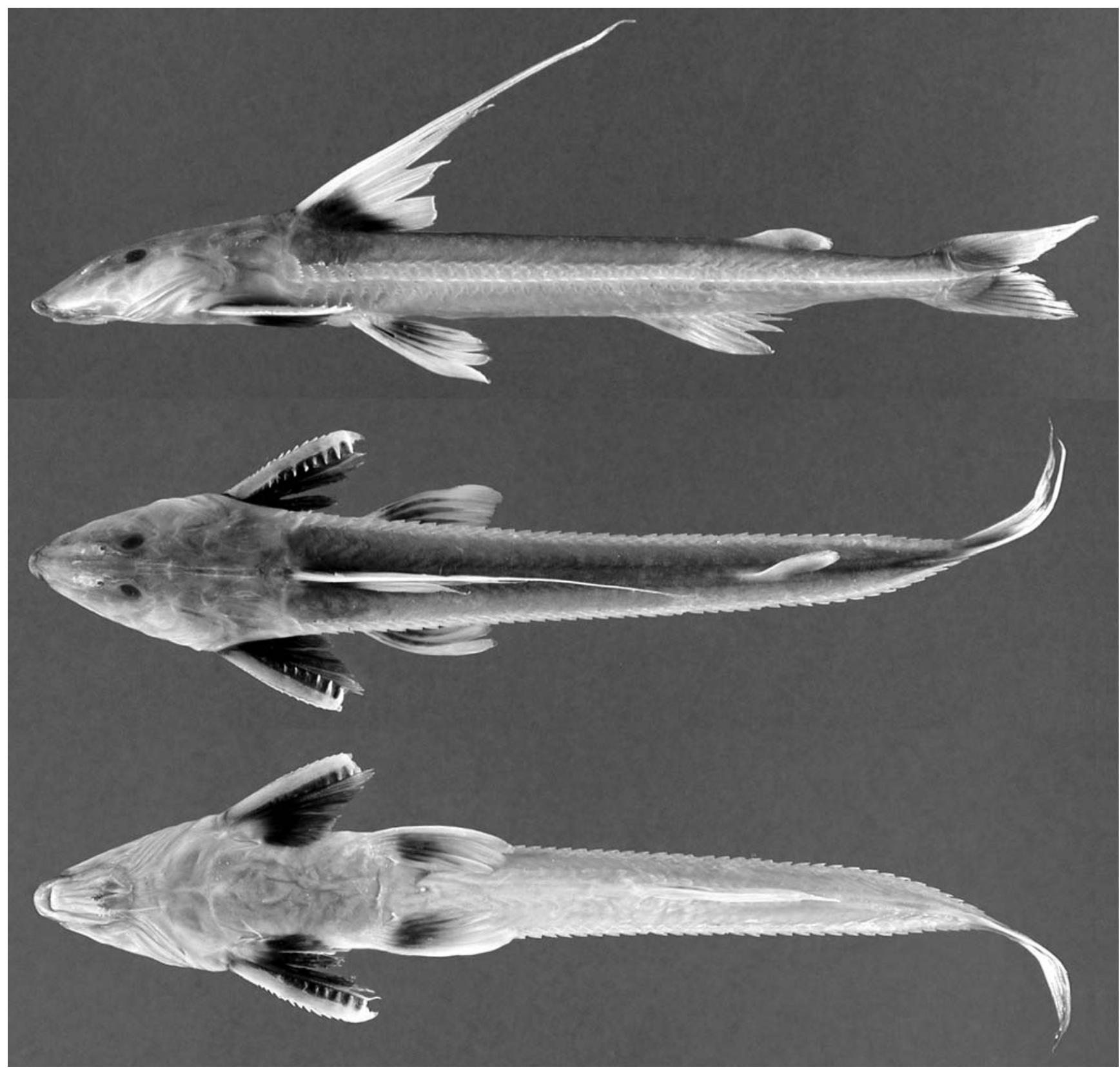

Fig. 26. Leptodoras juruensis, ANSP 180930 (SL 149 mm), rio Solimões (Amazonas dr.), 14 km upstream from Nova Tonantins, Amazonas, Brazil. 
14 Nov 1993, JGL-93-056; FMNH 116139 (6), rio Içá (Amazonas dr.), between towns Betania and São Antônio do Içá ( $3^{\circ} 8^{\prime} 46^{\prime \prime S}$, 68²'10"W), 19 Nov 1993, JGL-93-089; FMNH 116140 (1), rio Solimões (Amazonas dr.), between towns Gr. Rural Muiraquita and São Antônio do Içá (3¹0’39"S, 6755’40"W), 21 Nov 1993, JGL93-103; FMNH 116141 (2), rio Solimões (Amazonas dr.), between towns Gr. Rural Muiraquita and São Antônio do Içá ( $3^{\circ} 10^{\prime} 40^{\prime \prime S}$, 6755’41"W), 21 Nov 1993, JGL-93-104; FMNH 116142 (1), rio Solimões (Amazonas dr.), between towns São Antônio do Içá and Nova Tonantins (30’28"S, 6752’30"W), 23 Nov 1993, JGL-93121; FMNH 116143 (1), rio Solimões (Amazonas dr.), between towns São Antônio do Içá and Nova Tonantins ( $\left.3^{\circ} 0^{\prime} 33^{\prime \prime S}, 67^{\circ} 52^{\prime} 33^{\prime \prime W}\right), 23$ Nov 1993, JGL-93-122; FMNH 116144 (2), rio Solimões (Amazonas dr.), between towns Codajás and Anori (3॰52'52"S, 61 44'2"W), 29 Nov 1993, JGL-93-141; FMNH 116145 (2), rio Solimões (Amazonas dr.), between towns Codajás and Anori ( $\left.3^{\circ} 48^{\prime} 49^{\prime \prime} \mathrm{S}, 61^{\circ} 38^{\prime} 26^{\prime \prime} \mathrm{W}\right)$, 29 Nov 1993, JGL-93-145; FMNH 116146 (3), rio Solimões (Amazonas dr.), between towns Anori and Porto São Francisco (3॰36'10"S, 61²1'19"W), 29 Nov 1993, JGL-93-147; FMNH 116147 (1), rio Solimões (Amazonas dr.), between towns Baronesa and Alvaraes (37'11"S, 6453'18"W), 31 Oct 1993, JPF-93-023; FMNH 116148 (3), rio Solimões (Amazonas dr.), between towns Alvaraes and Pananim ( $\left.3^{\circ} 11^{\prime} 17^{\prime \prime S}, 6^{\circ} 48^{\prime} 47^{\prime \prime W}\right), 31$ Oct 1993, JPF93-025; FMNH 116149 (7), rio Solimões (Amazonas dr.), between towns Vitória and Vai-Quem-Quer (2³4’33"S, 6546’34"W), 5 Nov 1993, JPS-93-017; FMNH 116150 (4), rio Solimões (Amazonas dr.), between towns Tamanicoa and Palheta $\left(2^{\circ} 35^{\prime} 45^{\prime \prime} \mathrm{S}, 65^{\circ} 31^{\prime} 0^{\prime \prime} \mathrm{W}\right), 5$ Nov 1993, JPS-93-023; FMNH 116151 (2), rio Solimões (Amazonas dr.), between towns Gr. Rural Muiraquita and Santo Antônio do Içá (39'6"S, 6754'37"W), 22 Nov 1993, JPS-93-075; FMNH 116152 (18), rio Solimões (Amazonas dr.), between twons Coadi and Alvaraes (38'26"S, 6451'21"W), 30 Oct 1993, OTO-93-006; FMNH 116153 (2), rio Solimões (Amazonas dr.), between towns Tamanicoa and Uara (2³9'2"S, 65³5'5"W), 6 Nov 1993, OTO-93-019; FMNH 116154 (8), rio Solimões (Amazonas dr.), between towns Foz do Jutaí and Fonte Boa (2³1'42"S, 66³6'32"W), 15 Nov 1993, OTO93-050; FMNH 116157 (2), rio Amazonas (Atlantic dr.), between towns Novo Oriente and São José do Amatari (3¹7'13"S, 58 54'59"W), 13 Oct 1994, FL-94-009; FMNH 116158 (4), rio Amazonas (Atlantic dr.), between towns Santa Antônia and Itacoatiara (3¹1'29"S, 58³1'16"W), 18 Oct 1994, FL-94-043; FMNH 116163 (4), rio Amazonas (Atlantic dr.), between towns Novo Oriente and São José do Amatari (317'14"S, 5854’30"W), 14 Oct 1994, JGL94-026; FMNH 116164 (1), rio Madeira (Amazonas dr.), between towns Vila Urucurituba and Santa Maria ( $\left.3^{\circ} 30^{\prime} 31^{\prime \prime S}, 58^{\circ} 53^{\prime} 38^{\prime \prime} \mathrm{W}\right)$, 17 Oct 1994, JGL-94-056; FMNH 116171 (1), rio Purus (Amazonas Dr.), upstream from Solimões (4³’51"S, 61³3’20"W), 27 Jul 1996, AMZ-96-066; FMNH 116172 (2), rio Solimões (Amazonas dr.), downstream from mouth of rio Purus ( $\left.3^{\circ} 35^{\prime} 3^{\prime \prime S}, 61^{\circ} 16^{\prime} 43^{\prime \prime W}\right), 28$ Jul 1996, AMZ-96-088; FMNH 116173 (4), rio Solimões (Amazonas

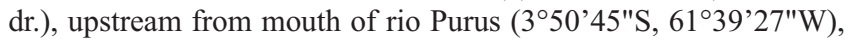
29 Jul 1996, AMZ-96-089; FMNH 116175 (1), rio Solimões (Amazonas dr.), downstream from mouth of rio Purus $\left(3^{\circ} 35^{\prime} 21^{\prime \prime S}\right.$, 615'29"W), 31 Jul 1996, AMZ-96-112; FMNH 116176 (15), rio Amazonas (Atlantic dr.), upstream from town of Itacoatiara ( $3^{\circ} 20^{\prime} 9^{\prime \prime} \mathrm{S}$, 58³6’11"W), 9 Aug 1996, AMZ-96-153; FMNH 116177 (2), rio Amazonas (Atlantic dr.), upstream from town of Itacoatiara (321'44"S, 58³9’32"W), 10 Aug 1996, AMZ-96-159; FMNH 116178 (1) rio Solimões (Amazonas dr.), between towns Vila Iranduba and Vila Careiro (313'25"S, 5956'29"W), 20 Jul 1996, CCF-96026; FMNH 116179 (1), rio Solimões (Amazonas dr.), between towns Vila Iranduba and Vila Careiro (3¹7’30"S, 60²’26"W), 21 Jul 1996,
CCF-96-036; FMNH 116180 (1), rio Solimões (Amazonas dr.), between towns Vila Iranduba and Vila Careiro ( $3^{\circ} 14^{\prime} 22^{\prime \prime} \mathrm{S}, 59^{\circ} 54^{\prime} 1$ 'W), 21 Jul 1996, CCF-96-042; FMNH 116181 (2), rio Solimões (Amazonas dr.), between towns Vila Iranduba and Vila Careiro (316’' ${ }^{\circ}$ S, 5955'1"W), 21 Jul 1996, CCF-96-044; FMNH 116182 (4), rio Amazonas (Atlantic dr.), between towns Nova Oriente and Itaquatiara (3¹8'25"S, 5853'19"W), 5 Aug 1996, CCF-96-070; FMNH 116183 (1), rio Amazonas, between towns Nova Oriente and Itaquatiara (3¹8'25"S, 58 53'19"W), 5 Aug 1996, CCF-96-070; FMNH 116184 (4), rio Amazonas (Atlantic dr.), between towns Manaus and Itacoatiara ( $\left.3^{\circ} 20^{\prime} 50^{\prime \prime S}, 58^{\circ} 38^{\prime} 44^{\prime \prime W}\right), 10$ Aug 1996, CCF-96-106; FMNH 116185 (3, 1 removed), rio Purus (Amazonas dr.), between towns Surara and Beruri (35 ' $\left.28^{\prime \prime} \mathrm{S}, 61^{\circ} 27^{\prime} 41^{\prime \prime} \mathrm{W}\right), 27$ Jul 1996, JGL-96-004; FMNH 116186 (1), rio Amazonas (Atlantic dr.), between towns Santo Antônio and Itacoatiara ( $3^{\circ} 20^{\prime} 48^{\prime \prime} \mathrm{S}$, 58³6’22"W), 30 Jul 1996, JGL-96-008; FMNH 116187 (1), rio Purus (Amazonas dr.), upstream from confluence with Solimões (344'12"S, 61²6'29"W), 26 Jul 1996, MTP-96-039; FMNH 116188 (6), rio Solimões (Amazonas dr.), downstream from mouth of rio Purus (3³6’1"S, 61²1’21"W), 28 Jul 1996, MTP-96-053; FMNH 116189 (10), rio Solimões (Amazonas dr.), downstream from mouth of rio Purus (3³6'6"S, 6120'51"W), 28 Jul 1996, MTP-96-054; FMNH 116190 (1), rio Solimões (Amazonas dr.), upstream from mouth of rio Purus (350'12"S, 61³9'22"W), 29 Jul 1996, MTP-96-066; FMNH 116191 (1), rio Solimões (Amazonas dr.), downstream from mouth of rio Purus $\left(3^{\circ} 26^{\prime} 11^{\prime \prime S}\right.$, 6044'17"W), 31 Jul 1996, MTP-96-095; FMNH 116192 (2), rio Amazonas (Atlantic dr.), upstream from mouth of Madeira (315'55"S, 5857'32"W), 4 Aug 1996, MTP-96-104; FMNH 116193 (3), rio Madeira (Amazonas dr.), downstream from town of Nova Olinda (3³8'26"S, 59²'45"W), 7 Aug 1996, MTP-96-126; FMNH 116194 (1), rio Amazonas (Atlantic dr.), upstream from town of Itacoatiara (320’22"S, 58³6’31"W), 8 Aug 1996, MTP96-134. Para: FMNH 116155 (1), rio Amazonas (Atlantic dr.), between towns Santarém and Monte Alegre (2 $25^{\prime}$ '46"S, 5425'18"W), 4 Nov 1994, AMZ-94-001; FMNH 116156 (2), rio Amazonas (Atlantic dr.), between towns Monte Alegre and Prainha (2²’45"S, 5358'54"W), 5 Nov 1994, AMZ-94-035; FMNH 116159 (3), rio Amazonas (Atlantic dr.), between towns Juruti and Óbidos (1 $\left.{ }^{\circ} 59^{\prime} 23^{\prime \prime S}, 55^{\circ} 47^{\prime} 50^{\prime \prime W}\right), 22$ Oct 1994, FL-94-060; FMNH 116160 (5), rio Amazonas (Atlantic dr.), between towns Óbidos and Santarém (2॰3'41"S, 55²1'45"W), 27 Oct 1994, FL-94-095; FMNH 116161 (6), rio Amazonas (Atlantic dr.), between towns Óbidos and Santarém (2॰4'39"S, 55²0'53"W), 27 Oct 1994, FL94-097; FMNH 116165 (11), rio Amazonas (Atlantic dr.), between towns Óbidos and Santarém (159’59"S, 55²5’46"W), 27 Oct 1994, JGL-94-081; FMNH 116166 (2), rio Amazonas (Atlantic dr.), be-

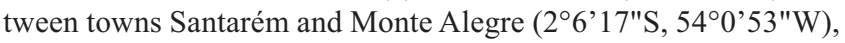
5 Nov 1994, JGL-94-092; FMNH 116167 (1), rio Amazonas (Atlantic dr.), between towns Santarém and Monte Alegre (2 $4^{\prime} 52^{\prime \prime S}$, 5359'55"W), 4 Nov 1994, LRP-94-011; FMNH 116169 (1), rio Amazonas (Atlantic dr.), between towns Almeirim and Gurupa (1²7’45"S, 525'36"W), 11 Nov 1994, LRP-94-052; FMNH 116170 (2), rio Amazonas (Atlantic dr.), between towns Almeirim and Gurupa (1²9'51"S, 5150’30"W), 14 Nov 1994, LRP-94-060. Peru: Loreto: ANSP 112321 (1, $125.23 \mathrm{~mm})$, ANSP 112322 (5, 70.3-93.26 mm), río Amazonas (Atlantic dr.), vicinity of Iquitos, between Isla Iquitos and Isla Lapuna, near I. Lapuna shore, 9 Oct 1955, P55-9; INHS 39465 (2, 94.5, 117.4 mm), río Amazonas (Atlantic Dr.), playa Cañaves, 20 minutes south of Gallito by boat, 21 Aug 1996; SIUC 29522 (1, 127.0 mm) río Momon (Amazonas dr.), near Iquitos, Jul 1995. 


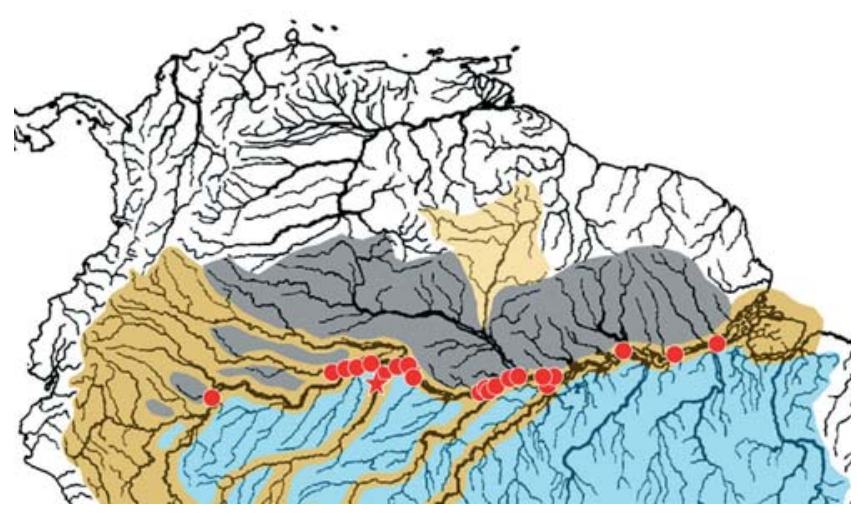

Fig. 27. Distribution of Leptodoras juruensis (star denotes type locality).

\section{Leptodoras myersi Böhlke, 1970}

Figs. $4 \mathrm{i}, 19 \mathrm{c}$ and 28

Leptodoras myersi Böhlke 1970: 54, figs. 1, 2 (type locality: río Amazonas, Atlantic dr., between Isla Iquitos and Isla Lapuna, near Isla Lapuna shore, vicinity of Iquitos, Loreto, Peru).

Diagnosis. Distinguished among Leptodoras by three unique characteristics, the latter two noted in its original diagnosis (Böhlke 1970:54-55): body dorsoventrally depressed, greatest body depth $58-61 \%$ of cleithral width ( $v s . \geq 66 \%$ in other Leptodoras), broad dusky nuchal saddle extending ventrally across tympanum and postcleithral process, finishing on the lower side level with the pelvic-fin origin (absent in other Leptodoras), and skin on head, particularly snout, ornamented with thin elongate pale ridges ( $v s$. round bumps or short and/ or thick ridges in other Leptodoras).

Description. Head and body very dorsoventrally depressed, body moderately elongate, predorsal distance, particularly snout, relatively long, ventrally flattened from snout to vent, caudal peduncle rather long and shallow, depressed. Eye comparatively small with very little or no adipose eyelid.

Mouth subterminal, jaws edentulous in adults and juveniles as small as $55 \mathrm{~mm}$ SL. Maxillary barbel comparatively short, not reaching ventromedial extent of gill opening. Secondary maxillary barbels 7-9 (modally 8), flattened, overlapping proximally, well separated distally; proximal secondary maxillary barbels with fimbriate anterior margin and smooth posterior margin; distal ones smooth. Oral hood comparatively short overall (i.e., not greatly expanded posteriorly) and very similar to that described for $L$. juruensis with following exceptions: upper labial extension more expanded, broadly rounded distally, lateral margin usually with few small fimbriae, and jaw barbels more densely ornamented with elongate papillae. Branchiostegal membrane with narrow fleshy margin weakly overlapping ventral gill opening; fleshy inner flap along cleithrum absent. Morphology of first gill arch similar to L. cataniai.

Sum of midlateral plates 74-79 (modally 74 and 76, Table
3). Anterior midlateral plates comparatively shallow, covering about $1 / 4$ of corresponding body depth; posterior margins of dorsal and ventral wings rounded with few small serrae. Tympanum with 2 or 3 very small ossifications along postotic laterosensory canal, posterior-most usually appearing as weak spine; small fixed spine along posterior margin supracleithrum present but usually inconspicuous. Postcleithral process moderately elongate with bluntly pointed tip; proximal dorsal margin strongly concave (hemicircular), dorsoposterior margin shallowly convex. Middorsal groove on nuchal shield well defined. Subrectangular nuchal foramina present, replacing suture between epioccipital and anterior nuchal plate. Skin with many short thin fleshy ridges scattered over snout.

Dorsal-fin rays I,6; pectoral-fin rays I,9-10 (modally 10); pelvic-fin rays i,6; total anal-fin rays 14 (first 5 unbranched); caudal-fin rays i,8/9,i; dorsal procurrent caudal-fin rays 1618 , ventral procurrent caudal-fin rays 14-17. Dorsal-fin spine sturdy, short, straight, attenuate; anterior denticulations antrorse, small, inconspicuous; posterior denticulations straight, small, well separated and confined to distal half. Pectoral-fin spine sturdy, moderately elongate, anterior margin weakly curved, posterior margin nearly straight, tip blunt; anterior denticulations antrorse, moderately sized nearly to tip; posterior denticulations well developed, becoming gradually larger and less retrorse towards tip of spine (last and/or penultimate denticulation nearly perpendicular to long axis of spine); last posterior denticulation terminal, its lateral margin continuous with tip of pectoral spine. Pelvic fin comparatively long and bluntly pointed. Anal fin triangular; tip of longest branched ray more or less even with base of last branched ray when fin extended. Caudal fin forked with pointed lobes.

Coloration in alcohol. Coloration unique among Leptodoras: broad dusky saddle on nuchal shield extending ventrally across tympanum and postcleithral process, finishing on lower side level with pelvic-fin origin. Remaining head and body weakly countershaded, dorsal surfaces dusky, lower sides and undersurfaces white. Head often with dusky oblique bar along posterior margin of operculum and small dusky patch on anterior face of cleithrum.

Dorsal fin with few small melanophores scattered on bases of spine, rays and skin covering insertion. Pectoral fin membranes dusky with scattered melanophores, pectoral spine and rays relatively depigmented. Pelvic and anal fins depigmented, cream, hyaline. Caudal fin with faint dusky stripe on upper half of lower lobe; even fainter one occasionally on lower half of upper lobe (Böhlke 1970:59).

Coloration in life. In some live specimens (Fig. 19c) nuchal saddle and bar are intensely black, as are pectoral fin and posterior margin of operculum; countershading more evident, gray-blue above midlateral thorns, white below; asymmetry of caudal fin pigmentation more pronounced with lower lobe darker than upper as in L. juruensis. 
Distribution. Until recently Leptodoras myersi was known only from the type series collected by trawling a swift flowing channel of the río Amazonas near Iquitos, Peru (Fig. 13). Additional specimens were recently collected in the same vicinity over large sand/silt shoals where this species is syntopic with L. cf. cataniai and L. juruensis.

Type-material examined. Leptodoras myersi: holotype, ANSP
112318 (1, $73.75 \mathrm{~mm})$, Peru, Loreto, río Amazonas (Atlantic Dr.), vicinity of Iquitos, between Isla Iquitos and Isla Lapuna, near Lapuna shore, 9 Oct 1955, C.C.G. Chaplin and R. Patrick, P55-9. Paratypes (12): ANSP 112319 (9, 54.7-76.7 mm), ANSP 112320 (1, c\&s), USNM 203816 (2, 67.5, 74.2 mm), same data as holotype.

Non-type material. Peru: Loreto: ANSP 181045 (12), río Amazonas (Atlantic dr.), near Iquitos, 4 Aug 2005.

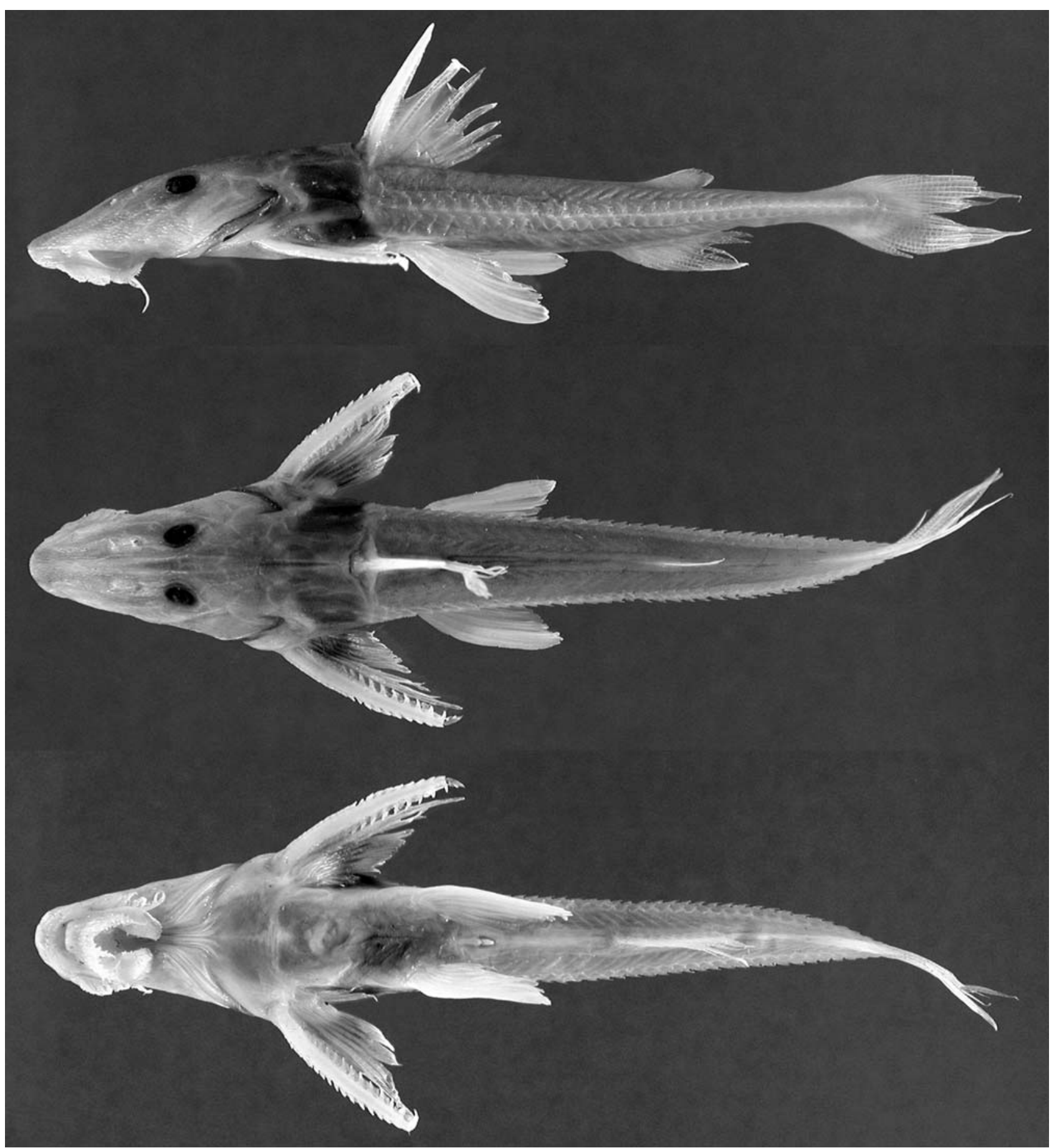

Fig. 28. Leptodoras myersi, paratype, ANSP 112319 (SL 76 mm), río Amazonas (Atlantic dr.), vicinity of Iquitos, Loreto, Peru. 


\section{Discussion}

Examination of specimens of Leptodoras from throughout its range verified the distinctiveness of seven previously recognized species: L. acipenserinus, L. copei, L. hasemani, L. juruensis, L. linnelli, L. myersi, and L. praelongus. In addition, three new species were discovered: Leptodoras nelsoni, L. rogersae, and L. cataniai.

Species were diagnosed in Leptodoras by one to several unique characteristics (L. praelongus, hasemani, linnelli, juruensis, myersi, cataniai), or by a unique combination of characteristics (L. copei, L. acipenserinus, L. nelsoni, L. rogersae). Similar-looking species (L. linnelli, $L$. acipenserinus, L. cataniai, L. nelsoni, L. rogersae) were further distinguished by morphometric characteristics. Principal components analysis (PCA) of 34 mensural characters resolved these species into four non-overlapping clusters corresponding to $L$. linnelli, $L$. rogersae, $L$. cataniai and $L$. acipenserinus + L. nelsoni (Fig. 3a). Measurements most useful for discriminating among these species included oral hood length, plate depth, adipose eye diameter, postcleithral process length, anal fin base, interorbital width, pelvic fin length, snout length and caudal peduncle length.

PCA (Fig. 3b) partially resolved L. cataniai into three weakly overlapping clusters corresponding to L. catania sensu stricto (in the Negro) and two forms treated as L. cf. cataniai (one in the Amazon, the other in the Nanay). The greatest separation was between $L$. catania sensu stricto and the Nanay form with the Amazon form intermediate. Measurements contributing to their separation were associated largely with the snout, oral hood and adipose eye. Leptodoras catania sensu stricto included specimens from blackwater habitats in the rio Negro basin (Amazonas dr.) characterized by a relatively short snout, large adipose eye and intermediate oral hood length. The Amazon form included specimens from whitewater habitats (largely in the main channel of the rio Amazonas and its larger tributaries) with a comparatively short oral hood and intermediate snout and adipose eye. A single adult specimen from the rio Branco, a moderately whitewater tributary of the rio Negro, grouped more closely with the Amazon form than with $L$. catania sensu stricto. The Nanay form included specimens from the río Nanay, a moderately blackwater tributary of the upper rio Amazonas, and a site on the río Ucayali. The Nanay form was characterized by a comparatively small adipose eye and a long snout and oral hood. In addition to morphometrics the three forms were somewhat distinguishable by sums of midlateral plates (Table 3 ): mode 82 (range 79$86)$ in the Nanay form, $84(82-87)$ in L. catania sensu stricto and 88 (83-92) in the Amazon form.

It is unknown whether the observed differences between the three forms of L. cataniai represent eco-phenotypic or genetic-based variation. The distributions of these three forms (and of many other doradid species and forms) are weakly to strongly correlated with the three general categories of water chemistry commonly associated with South American rivers (summarized in Goulding et al., 1996): whitewaters (muddy or sediment-rich), clearwaters (sediment-poor), and blackwaters (sediment-poor, tannin-stained, usually acidic). Rivers with headwaters in the Andes are sediment-rich whitewaters. Rivers that drain geologically older uplands to the east of the Andes (e.g., Brazilian and Guiana Shields) are often clear or nearly so. Rivers that drain predominantly lowland, sandy soils tend to be blackwaters. Some rivers are relatively easy to categorize whereas others represent intermediate conditions. Furthermore, although the main channel of the Amazon is distinctly whitewater, its tributaries range along a continuum from white (e.g., Madeira, Juruá) to black (Negro) to clearwaters (Tapajós, Xingu). Likewise, the blackwater rio Negro has moderately turbid tributaries (e.g., Branco). As a result, the Amazon basin is a complex mosaic of various water chemistries. Likewise, the geographic distributions of the three forms of $L$. cataniai are likely to be more complex than described herein, and may represent a parallel mosaic pattern if each form prefers certain water conditions.

The extent to which differences in water chemistry act as barriers to dispersal and gene flow among the three forms of L. cataniai is not known. Equally unknown is the extent to which morphological differences in the three forms can be attributed to local adaptations to water quality vs. historical vicariance events that may have once isolated certain populations. The observed differences between the three forms may be a product of both, perhaps initiated by vicariance and currently maintained by conditions related to water chemistry. Molecular data are needed to assess levels of gene flow between the three forms and the relative independence of their evolutionary trajectories (sensu Dowling et al., 1992). Given the absence of such data and the incomplete knowledge of their distributions it seems premature to decide whether the three forms of L. cataniai represent clinal variation or discrete taxa (i.e., species or subspecies).

\section{Acknowledgements}

Many individuals and institutions have greatly facilitated this research by making specimens available for study and hosting museum visits. For this I sincerely thank: B Brown and S. Schaefer (AMNH); D. Didier Dagit, J. Lundberg and W. Saul (ANSP); J. Armbruster (AUM); O. Crimmen, P. Campbell and A. Gill (BMNH); D. Catania, W. Eschmeyer and T. Iwamoto (CAS); P. Petry, M.A. Rogers and K. Swagel (FMNH); C. Mayer (INHS); J. Friel (CU); J. Seigel and R. Feeney (LACM); F. Provenzano (MBUCV); D. Taphorn (MCNG); R. Reis (MCP); K. Hartel (MCZ); P. Pruvost, G. Duhamel and J.-C. Hureau (MNHN); H. Wellendorf and E. Mikschi (NMW); E. Holm, M. Rouse and R. Winterbottom (ROM); B. Burr and J. Stewart (SIUC); D. Nelson (UMMZ), C. Agostinho and P. Lucinda (UNT), S. Jewett, L. Palmer, S. Raredon and R. Vari (USNM) and M. Hardman. An equally large number of people have assisted me in the field and lab and in particular I wish to thank: C. Allison, M. Arce, J. Armbruster, A. Bullard, O. Castillo, C. DoNascimiento, K. Elkin, M. Hardman, M. Littmann, A. López, N. Lovejoy, N. Lujan, M. 
McGowan, G. Moyer, M. Pérez, N. Salcedo, B. Sidlauskas, G. Slugocki, L. Sousa, J. Stewart, M. Thomas and D. Werneke. Special thanks to L. Page for his patient support and thoughtful guidance during much of this study conducted in partial fulfillment of a doctoral degree from the University of Illinois. Additional thanks to the other members of my doctoral committee: W. Chen, A. DeVries, F. Frazzetta, C. Phillips and T. Uzzell. This project was funded in part by a grant from the US National Science Foundation (DEB-0315963) to MHS (and co-PIs) entitled Planetary Biodiversity Inventory: All Catfish Species (Siluriformes) - Phase I of an Inventory of the Otophysi.

\section{Literature Cited}

Böhlke, J. E. 1970. A new species of the doradid catfish genus Leptodoras, with comments on related forms. Proceedings of the California Academy of Sciences, 38(3): 53-61.

Bookstein, F. L. 1989. "Size and shape": a comment on semantics. Systematic Zoology, 38: 173-180.

Boulenger, G. A. 1898. Descriptions of two new siluroid fishes from Brazil. Annals and Magazine of Natural History, 2(12): $477-478$.

Dowling, T. E., W. L. Minckley, M. E. Douglas, P. C. Marsh \& B. D. DeMarais. 1992. Response to Wayne, Nowak, and Phillips and Henry: use of molecular characters in conservation biology. Conservation Biology, 6: 600-603.

Eigenmann, C. H. 1910. Catalogue of the fresh-water fishes of tropical and south temperate America. Reports of the Princeton University expeditions to Patagonia 1896-1899. Zoology, 3(4): 375-511.

Eigenmann, C. H. 1912. The freshwater fishes of British Guiana, including a study of the ecological grouping of species, and the relation of the fauna of the plateau to that of the lowlands. Memoirs Carnegie Museum, 5(1): i-xxii + 1-578.

Eigenmann, C. H. 1925. A review of the Doradidae, a family of South American Nematognathi, or catfishes. Transactions American Philosophical Society, 22(5): 280-365.

Etnier, D. A. \& W. C. Starnes. 1993. The fishes of Tennessee. University of Tennessee Press, Knoxville. xiv +681 p.

Fernández-Yépez, A. 1968. Contribucion al conocimiento de la familia Doradidae en Venezuela. Boletin del Instituto Oceanographico de la Universidad de Oriente, 7(1): 7-72.

Goulding, M., N. J. H. Smith \& D. J. Mahar. 1996. Floods of fortune: ecology and economy along the Amazon. Columbia University Press, New York. 193 p.
Günther, A. 1868a. Diagnoses of some new freshwater fishes from Surinam and Brazil, in the collection of the British Museum. Annals Magazine Natural History, 1(6): 475-481.

Günther, A. 1868b. Descriptions of freshwater fishes from Surinam and Brazil. Proceedings of the Zoological Society of London, 1868(2): 229-247.

Higuchi, H. 1992. A phylogeny of the South American thorny catfishes (Osteichthyes; Siluriformes, Doradidae). Unpublished Ph.D. Dissertation, Harvard University, Cambridge.

Higuchi, H., H. A. Britski \& J. C. Garavello. 1990. Kalyptodoras bahiensis, a new genus and species of thorny catfish from northeastern Brazil (Siluriformes: Doradidae). Ichthyological Exploration of Freshwaters, 1(3): 219-225.

Hubbs, C. L. \& K. F. Lagler. 1958. Fishes of the Great Lakes region. Cranbrook Institute of Science Bulletin No. 26. xiii +213 pp.

Jolicoeur, P. 1963. The multivariate generalization of the allometry equation. Biometrics, 19: 497-499.

Jolicoeur, P. \& J. E. Mosimann. 1960. Size and shape variation in the painted turtle, a principal component analysis. Growth, 24: 339-354.

Leviton, A. E., R. H. Gibbs, Jr., E. Heal \& C. E. Dawson. 1985. Standards in herpetology and ichthyology. Part I. Standard symbolic codes for institutional resource collections in herpetology and ichthyology. Copeia, 1985(3): 802-832.

McElroy, D. M. \& M. E. Douglas. 1995. Patterns of morphological variation among endangered populations of Gila robusta and Gila cypha (Teleostei: Cyprinidae) in the upper Colorado River basin. Copeia, 1995(3): 636-649.

Myers, G. S. \& S. H. Weitzman. 1956. Two new Brazilian fresh water fishes. Stanford Ichthyological Bulletin, 7(1): 1-4.

Page, L. M. \& B. M. Burr. 1991. A field guide to freshwater fishes. North America. North of Mexico. The Peterson Field Guide Series, Boston. v-xii +432 p.

Santos, G. M., M. Jégu \& B. de Merona. 1984. Catálogo de peixes comerciais do baixo rio Tocantins. Projeto Tucuruí, Eletronorte/CNPq/INPA, Manaus. 83 p.

Steindachner, F. 1915. Beiträge zur Kenntnis der Flussfische Südamerikas (V). Anzeiger der kaiserlichen Akademie Wissenshaften, 52(18): 217-219.

Received July 2005

Accepted November 2005 